\title{
Racial Heterogeneity and Local Government Finances: Evidence from the Great Migration
}

\section{Citation}

Tabellini, Marco. "Racial Heterogeneity and Local Government Finances: Evidence from the Great Migration." Harvard Business School Working Paper, No. 19-006, July 2018.

\section{Permanent link}

http://nrs.harvard.edu/urn-3:HUL.InstRepos:37326939

\section{Terms of Use}

This article was downloaded from Harvard University's DASH repository, and is made available under the terms and conditions applicable to Open Access Policy Articles, as set forth at http:// nrs.harvard.edu/urn-3:HUL.InstRepos:dash.current.terms-of-use\#OAP

\section{Share Your Story}

The Harvard community has made this article openly available.

Please share how this access benefits you. Submit a story.

\section{Accessibility}


Racial Heterogeneity and Local Government Finances: Evidence from the Great Migration

Marco Tabellini

Working Paper 19-006 


\title{
Racial Heterogeneity and Local Government Finances: Evidence from the Great Migration
}

\author{
Marco Tabellini
}

Harvard Business School

Working Paper 19-006 


\title{
Racial Heterogeneity and Local Government Finances: Evidence from the Great Migration*
}

\author{
Marco Tabellini ${ }^{\dagger}$ \\ Harvard Business School
}

July 18, 2018

\begin{abstract}
Is racial heterogeneity responsible for the distressed financial conditions of US central cities and for their limited ability to provide even basic public goods? If so, why? I study these questions in the context of the first wave of the Great Migration (19151930), when more than 1.5 million African Americans moved from the South to the North of the United States. Black inflows and the induced white outflows ("white flight") are both instrumented for using, respectively, pre-migration settlements and their interaction with MSA geographic characteristics that affect the cost of moving to the suburbs. I find that black in-migration imposed a strong, negative fiscal externality on receiving places by lowering property values and, mechanically, reducing tax revenues. Unable or unwilling to raise tax rates, cities cut public spending, especially in education, to meet a tighter budget constraint. While the fall in tax revenues was partly offset by higher debt, this strategy may, in the long run, have proven unsustainable, contributing to the financially distressed conditions of several US central cities today.
\end{abstract}

JEL Codes: H41, J15, N32.

${ }^{*}$ I am extremely grateful to Daron Acemoglu, Alberto Alesina, and Heidi Williams for their invaluable advice and guidance. Special thanks to David Autor, Maristella Botticini, Leah Boustan, James Feigenbaum, Nicola Gennaioli, and Francesco Giavazzi for their many comments and suggestions. I also thank Abhijit Banerjee, Alex Bartik, Sydnee Caldwell, Enrico Cantoni, Michela Carlana, Leonardo D'Amico, Christian Dustmann, Dan Fetter, John Firth, Nicola Fontana, John Friedman, Chishio Furukawa, Nina Harari, Greg Howard, Ray Kluender, Giacomo Magistretti, Bob Margo, Arianna Ornaghi, Jonathan Petkun, Jim Poterba, Otis Reid, Jósef Sigurdsson, Cory Smith, Jim Snyder, Martina Uccioli, Nico Voigtlaender, Daniel Waldinger, and Roman Zarate for useful conversations and suggestions. Viola Corradini provided excellent research assistance. I am thankful to the George and Obie Shultz Fund and to IGIER for their generous funding. All remaining errors are mine.

${ }^{\dagger}$ mtabellini@hbs.edu 


\section{Introduction}

Central cities-suburbs inequality is a recurrent feature of US Metropolitan Statistical Areas (MSAs). Such inequality is evident along a number of dimensions: inner city residents are usually poorer, less educated, less likely to be white, and live further away from well-paying jobs relative to their suburban counterparts (Table 1). Moreover, affluent suburbs often provide higher quality public goods and services, relative to those offered inside the urban ring (Boustan, 2013). In turn, disparity in the quality of and in access to key public goods such as education and health care is considered one of the main factors behind the persisting inner cities-suburbs, and the related racial, inequality (see, among others, Fryer and Katz, 2013, or Katz, 2015). ${ }^{1}$

One commonly proposed explanation for why US cities are chronically unfunded and often unable to provide adequate levels of public goods is racial heterogeneity. First, racial heterogeneity can reduce demand for public services either because non-coethnics have conflicting preferences over government spending or because whites' utility from public goods falls when these have to be shared with non-white individuals (Alesina et al., 1999). In turn, lower demand for public spending can reduce government revenues, via cuts in the tax rate.

Second, white residents can respond to racial heterogeneity by leaving the central city and relocating to richer and more racially homogeneous suburbs (Boustan, 2010). Alternatively, prospective white migrants may choose not to move to the central city precisely because of higher racial heterogeneity. In either case, demand for housing in the inner city falls, driving down house prices and possibly encouraging a long-lasting process of urban decline (Glaeser and Gyourko, 2005). Since most local government revenues come from property taxes, reductions in property values can impose a negative fiscal externality on central cities (Boustan, 2012). Raising taxes may not be enough to compensate for the deterioration of the tax base, and cities may be forced to cut spending and increase debt to deal with a tighter budget constraint.

In this paper, I investigate whether racial heterogeneity contributes to the distressed financial conditions and the poor provision of public goods in US central cities. I study the effects of the Great Migration (1915-1930) of 1.5 million southern born African Americans on government finances and public spending of US northern cities, and test the two channels (fiscal externality vs demand for public goods) discussed above. ${ }^{2}$ When answering this

\footnotetext{
${ }^{1}$ Very recent trends suggest that poverty and inequality might be spreading to the suburbs as well (Kneebone, 2017). In particular, while suburban areas that are further away from the central cities are still thriving, standards of living and the quality of local amenities (including schools and hospitals) are deteriorating in inner suburbs (Allard, 2017).

${ }^{2}$ Throughout the paper, when referring to northern cities, I mean cities outside the South. I follow the Census definition of the South, but, as in Boustan (2010), I exclude the border state of Maryland, which
} 
question, two sources of endogeneity must be addressed. First, black migrants likely moved to places with better employment opportunities or with more appealing tax-public spending bundles. Second, white residents reacted to black inflows by "fleeing" to the suburbs and leaving racially diverse neighborhoods (Boustan, 2010; Shertzer and Walsh, 2016).

To deal with the first concern, I follow Boustan (2010) and, after estimating outmigration from each southern state for each decade, I assign migrants to northern cities exploiting 1900 clusters of southern born blacks. To reduce concerns that black outflows were differentially affected by local conditions in northern cities, I also predict outmigration from southern counties relying solely on origin-specific factors at the beginning of each decade. I then aggregate such predicted flows to the state level, and apportion them to each northern destination according to blacks' pre-existing settlements.

To address the second source of endogeneity, predicted black inflows are interacted with a number of geographic characteristics (presence of hills, lakes, oceans, and rivers) of the area surrounding central cities that should increase the cost that whites faced when moving to the suburbs. Intuitively, black arrivals increased whites' desire to relocate to the suburbs. However, their ability to do so depended on house prices and on the costs they incurred when commuting from the suburbs to the central city. ${ }^{3}$ For instance, in areas with more hills or water bodies, house prices are higher and commuting is more expensive, suggesting that, ceteris paribus, the white flight should be lower.

Using this empirical strategy, I find that black inflows had a strong, negative effect on tax revenues, which was entirely due to declining property values rather than to changes in the tax rate. My estimates suggest that, for the median city in my sample, Omaha (NE), the Great Migration reduced per capita tax revenues (resp. property values) by 6\% (resp. $8 \%$ ) relative to their 1910 levels. The reduction in house prices is consistent with lower demand for housing from whites who reacted to black inflows by moving to the suburbs or by choosing not to migrate to the central city (Boustan, 2010; Shertzer and Walsh, 2016). I provide suggestive evidence that the decline in housing demand was due to a combination of the white flight and lower in-migration of whites who would have moved to the central city absent black inflows, and who chose not to do so precisely because of the arrival of African Americans. I corroborate the interpretation that the Great Migration increased whites' demand for suburbanization in several ways.

First, I repeat the analysis without controlling for white population, and show that the estimated effect of black in-migration is larger (in absolute value) than in my baseline

received substantial net in-migration of blacks during the Great Migration (see appendix Table A1 for the list of southern states).

${ }^{3}$ Between 1910 and 1930, most jobs were still concentrated in central cities, and so individuals living in the suburbs largely needed to commute every day for work (Jackson, 1985). 
specification. This pattern suggests that the negative effect of the Great Migration was at least partly mediated by whites' residential decisions. Second, I split the sample between high and low growth cities, and test whether black arrivals had a differential effect on city finances depending on the local conditions of the housing market. As expected, the reduction in property values was significantly larger in cities with population growth below the median. Exploiting information gathered from historical newspapers, I also document that the arrival of African Americans was associated with a significant increase in terms such as "ghetto", "decay", and "segregation", but only in low growth cities, precisely where the (negative) effects of the white flight should have been more pronounced.

Third, black in-migration slowed down the construction of new housing units and the expansion of cities' boundaries. Finally, in MSAs that received more blacks between 1910 and 1930, the number of local jurisdictions increased more between 1940 and 1970, while more highways were planned in the Federal Highway Act (1944) and eventually built in subsequent decades. ${ }^{4}$ These findings are consistent with the idea that black in-migration increased whites' demand for suburbanization, as proxied by highways. Once in the suburbs, whites set up their own local jurisdictions so as not to share public goods with poorer blacks (Alesina et al., 2004; Burns, 1994), and resisted annexation to the central city (Danielson, 1976). ${ }^{5}$

Having established that black arrivals lowered property values and worsened city finances, I show that the Great Migration also reduced public goods provision. Consistent with changes in demand for redistribution, induced by racial or income considerations, spending cuts were larger in categories where either inter-racial interactions are more salient (education) or poorer African Americans would have obtained larger implicit transfers (sanitation and garbage collection). However, the fall in public spending was an order of magnitude smaller than that in tax revenues, as cities increased debt to make up for the lost (property) taxes.

As discussed above, a negative relationship between racial heterogeneity and public goods can be due to two mechanisms. First, a reduction in the desired level of spending; second, a negative fiscal externality, due to the deterioration of government finances induced by lower house prices. The substantial drop in property values, the heterogeneous patterns which depended on the local conditions of the housing market, and the increase in public debt are all strongly consistent with a negative fiscal externality: as house prices fell, local government finances deteriorated, and cities were forced to borrow more and spend less to meet a tighter budget constraint. At the same time, the asymmetric reduction in spending (and, in

\footnotetext{
${ }^{4}$ Data constraints prevent me from looking at the contemporaneous change in the number of local jurisdictions: the Census of Governments started collecting this data only in 1942.

${ }^{5}$ Annexation was the most common for cities to expand their boundaries in this period (Jackson, 1985).
} 
education in particular) suggests that white residents' decision of how to cut spending was likely influenced by racial heterogeneity.

My findings speak to several strands of the literature. First, they are related to the papers that document a negative correlation between ethnic diversity and public spending across US cities (Alesina et al., 1999) and across countries (Alesina et al., 2001; Alesina and Glaeser, 2004). My paper contributes to this literature in two ways. First, by relying on panel data, which permit the inclusion of fixed effects, and by using an instrumental variable approach, I can more confidently identify causal effects. Second, I show that racial heterogeneity can affect public spending not only by altering natives' preferences for redistribution (Luttmer, 2001) or reducing agreement over budget allocation (Beach and Jones, 2017), but also by generating fiscal externalities that, in turn, impact on governments' ability to provide public goods to their citizens. Dahlberg et al. (2012) find that the inflow of refugees to Sweden between 1985 and 1994 reduced support for redistribution in receiving municipalities. ${ }^{6}$ I complement this work by showing that racial heterogeneity can have direct effects on actual policies and not only on natives' preferences.

Second, my paper complements the existing literature on the white flight (Boustan, 2010; Shertzer and Walsh, 2016) and on residential segregation (Card et al., 2008; Cutler et al., 1999 and 2008) by documenting the negative effects that these phenomena had on local government finances and, ultimately, on cities' ability to provide public services to their residents. Consistently with Boustan (2012), my results suggest that the white flight imposed a substantial fiscal externality, and possibly encouraged a persistent process of urban decline that may be at the roots of the current inequality between (poor) central cities and surrounding (rich) suburbs. While in the short run cities were able to partly absorb the negative shock to the available resources by increasing debt, this strategy may have not been sustainable in the medium to long run. In fact, it can even be one of the reasons for the financially distressed conditions of many US central cities today.

Because of the empirical setting, my findings are also related to the vast literature on the Great Migration. Several works have analyzed the effects of this massive episode of migration on either migrants (Collins and Wanamaker, 2014; Black et al., 2015) or residents of receiving places (Boustan, 2009, 2010, and 2017; Fouka et al., 2018; Shertzer and Walsh, 2016). I instead focus on a set of variables (government finances and public spending) overlooked by the existing literature that likely had an effect on outcomes of both migrants and natives.

Finally, my paper speaks to the growing literature on the political consequences of im-

\footnotetext{
${ }^{6}$ Nekby and Pettersson-Lidbom (2017) revisit the work by Dahlberg et al. (2012), and argue that findings in the latter paper might be sensitive to the sample used and to measurement of preferences for redistribution.
} 
migration. Dustmann et al. (2016) and Halla et al. (2017) show that immigration increased the vote share of right wing, extremist parties in Denmark and Austria respectively. For the US, Mayda et al. (2016) find that immigration had opposing effects on the vote shares of Democrats and Republicans, depending on the fraction of naturalized immigrants already living in receiving areas. ${ }^{7}$ My work complements this literature by analyzing the effects of in-migration on public spending and government finances, and by suggesting avenues for future work. For instance, a policy relevant question is whether the changes in electoral outcomes documented in the aforementioned papers lead to changes in public spending or in other policies.

The remainder of the paper is organized as follows. Section 2 describes the historical background of the first wave of the Great Migration. Section 3 discusses the potential channels through which racial heterogeneity can affect government resources and public spending. Section 4 describes my data, and Section 5 lays out the empirical strategy. Section 6 presents results for the effects of the Great Migration on city finances, and then explores the mechanisms. Section 7 performs several robustness checks. Section 8 concludes.

\section{Historical Background: The Great Migration}

Between 1915 and 1930, during the first wave of the Great Migration, more than 1.5 million African Americans left the rural South for northern cities. Such unprecedented migration wave was triggered by a number of push and pull factors (Boustan, 2017). On the one hand, World War I dramatically increased labor demand in northern industries while temporarily reducing European immigration, which was then permanently blocked by the Immigration Acts of the 1920s (Collins, 1997). Employers in the North started looking at southern born blacks as a source of cheap labor to replace European immigrants and to deal with the war-induced surge in demand. Between 1915 and 1919, more than 2 million jobs - most of them requiring minimal levels of skills - were created in northern cities, thereby increasing labor market opportunities for blacks (Boustan, 2017). On the other hand, a series of weather shocks hit the South in the early 1900s, reducing labor demand for agriculture, where most blacks were employed. ${ }^{8}$ Racism and violence provided further incentives for

\footnotetext{
${ }^{7}$ In a related paper, Tabellini (2018), I study the effects of European immigration to US cities between 1910 and 1930, exploiting variation induced by World War I and the Immigration Acts of the 1920s. I show that, even if immigrants brought economic prosperity to receiving cities, they nonetheless encountered significant political opposition.

${ }^{8}$ In 1892, a cotton pest - the Boll Weevil - entered in Texas and then spread throughout the South in subsequent decades, inducing substantial damages to local agriculture (Lange et al., 2009). In 1927, the Mississippi flood displaced a large number of agricultural workers in several counties of Mississippi, Louisiana, and Arkansas (Boustan et al., 2012; Hornbeck and Naidu, 2014).
} 
African Americans to leave the South (see Tolnay and Beck, 1990, among others). Pushed by these factors and attracted by newly available jobs, blacks started moving to the North, taking advantage of the recently completed railroad network (Collins and Wanamaker, 2014, and Black et al., 2015).

The combination of the factors discussed above, further reinforced by the process of chain migration, resulted in massive migration flows: between 1915 and 1930, approximately 1.5 million blacks moved from the rural South to the urban North of the United States, with the fraction of African Americans living in the North rising from 10\% in 1910 to 25\% in 1930 (Figures 1 and 2). More than $60 \%$ of African Americans settled in the five most common destinations - New York, Chicago, Los Angeles, Detroit, and Philadelphia - but black inmigration was a widespread phenomenon in many other large non-southern cities (Figure 3). As a result, the number of blacks living in northern urban areas increased dramatically, altering the racial composition of receiving places. For instance, in Chicago, Cleveland, or Youngstown (just to mention a few), the fraction of blacks over city population moved from $2 \%$ in 1910 to more than $8 \%$ in 1930 .

\section{Racial Diversity, Government Finances, and Public Spending}

Racial heterogeneity can affect government resources and public goods provision through at least two channels: first, by changing demand for public spending and preferences for redistribution; second, by reducing property values due to e.g. lower housing demand or disamenity effects and, in turn, imposing a fiscal externality on more diverse areas. In this section, I discuss each of these two channels separately, and derive some testable implications that will guide my empirical analysis.

\subsection{Demand for Public Goods and Preferences for Redistribution}

As discussed in Alesina et al. (1999) among others, racial diversity can reduce the desired level of public spending. On the one hand, people from different ethnicities and cultures may disagree on what they consider the optimal amount of government spending or its allocation across public goods (Beach and Jones, 2017). On the other, the literature has documented a strong tendency of individuals to be more altruistic with coethnics and less willing to redistribute towards non-coethnics (Luttmer, 2001; Dahlberg et al., 2012). Yet another reason for a negative effect of racial diversity on public spending is that the utility from consumption of public goods may be lower when these have to be shared with people from 
different races. ${ }^{9}$ As individuals want to spend less, they also demand lower taxes, implying that public resources should be lower in more diverse communities.

This discussion provides two testable predictions. First, if a negative relationship between ethnic diversity and government revenues were due to lower demand for public goods, one should also find a negative relationship between ethnic diversity and the tax rate. Second, the effect of racial heterogeneity on the demand for public goods (if any) should be stronger in categories where either inter-racial interactions are more salient (e.g. education) or poorer minorities would get larger implicit transfers (e.g. spending on poverty relief).

\subsection{White Flight and Fiscal Externality}

In addition to the "demand side" effects discussed in the previous paragraph, racial heterogeneity can affect government resources and public spending through the housing market. In particular, if natives have a distaste for living in racially diverse places, in-migration of a minority group may reduce house values and impose a negative fiscal externality on receiving areas (Boustan, 2010; Saiz and Wachter, 2011). The reduction in house prices induced by higher racial diversity should be larger in cities with lower population growth where housing demand is weaker: in these areas, the white flight (or, lower in-migration of whites from elsewhere) should raise the vacancy rate, in turn driving down house prices. This effect should instead be less severe in booming areas, where overall population growth should at least partly offset the effects of white departures on vacancy rates and house prices. ${ }^{10}$

In the US, most local government revenues come from property taxes. Hence, declining house values mechanically lower tax revenues and, potentially, impose a fiscal externality on areas experiencing in-migration (Boustan, 2012). While, in principle, the tax rate can be increased to compensate for a lower tax base, there may exist political and economic constraints that prevent municipalities from doing so. For instance, politicians may realize that, by increasing the tax rate, they would further depress housing demand and reinforce the process of urban decline. Also, precisely because of higher racial heterogeneity, voters may be reluctant to accept higher taxes. As a result, more diverse communities may be forced to cut spending and increase debt in order to meet a more binding budget constraint. Lower quality public goods and higher levels of indebtedness can also have a feedback effect on property values and trigger a self-reinforcing cycle of lower spending and worse government finances.

To sum up, if racial diversity affects public goods provision only through a fiscal exter-

\footnotetext{
${ }^{9}$ For instance, the utility that white parents get from sending their children to public schools may be lower when schools are more ethnically diverse (Baum-Snow and Lutz, 2011; Cascio and Lewis, 2012).

${ }^{10}$ Boustan (2010) presents a model that formalizes this idea.
} 
nality, one should find a negative effect on house prices and no (or a positive) effect on the tax rate. Moreover, this effect should be larger in cities where population growth is lower. When interpreting my results, I will use these predictions, and contrast them with those obtained above, to discriminate between the demand and the fiscal externality effects of ethnic diversity on public spending and government finances. In practice, both channels can be simultaneously at play. However, testing these predictions will allow me to shed some light on the relevance of each of the two mechanisms in my setting.

\section{Data}

My analysis is based on the three Census years that span the period of the first wave of the Great Migration, i.e. 1910, 1920, and 1930. The sample is composed of the 42 non-southern US central cities that were anchored to a MSA, had at least 100,000 residents in 1930, and for which it was possible to construct the instrument for black migration. ${ }^{11}$ The 42 cities in my sample (see Figure A1 and Table A2 for the complete list) absorbed more than 95\% of southern black migrants that settled in northern or western urban areas during the first wave of the Great Migration, and include more than $85 \%$ of the black, white, or city population of non-southern urban areas in each decade between 1910 and 1930.

For this project, I collected, and in many cases digitized, data from two main sources. First, I used data on city population by race in each decade from the (full count) Census of Housing and Population. From this source, I also collected data on the number of families, the number of dwellings, and other city-level socioeconomic and demographic characteristics used either as outcomes (in addition to public finance variables) or to perform robustness checks. $^{12}$ To construct the instrument for black migration, I used data from the $19005 \%$ sample and the 1910 to 1930 1\% samples of the US Census of Population made available by IPUMS (Ruggles et al., 2015), and from ICPSR study 2896 (Haines et al., 2010).

Second, I digitized a detailed dataset on public spending and city finances from the Financial Statistics of Cities. These are annual reports, available from 1906 onwards for cities with population above 30,000 or 100,000 , depending on the years. Since population data are available only at decennial frequencies, data from the Financial Statistics of Cities

\footnotetext{
${ }^{11}$ Consistently with Baum-Snow (2007) and Boustan (2010), central cities are defined as the largest urban center of a given MSA. My results appear robust to alternative definitions. Since I am interested in city-level fiscal outcomes, differently from Baum-Snow (2007) or Boustan (2010), I do not fix city boundaries. However, I do fix MSA boundaries as of 1940 in order to keep the geographic unit of analysis constant (results are unchanged when fixing these as of 1910 or 1970).

${ }^{12}$ Specifically, demographic and socioeconomic variables include: the fraction of the population below age 20; the fraction of foreign born whites, or with mixed parentage; the fraction of illiterate.
} 
were collected for years 1910, 1919, and $1930{ }^{13}$ In my analysis, I consider public spending (total and by category), tax revenues, tax rates, property values, and debt. ${ }^{14}$ Table 2 reports the summary statistics for the main variables used in my analysis. Table A3 in the appendix lists all variables with their respective sources.

\subsection{City Demographics and City Finances}

During this period, many northern and western cities were booming: for the 42 cities in my sample, the 1910-1930 average (median) population growth rate was as high as $60 \%$ (50\%). The median city rose from 215,000 residents in 1910 to almost 300,000 in 1930 (Table A4). Comparing these numbers to the post 1940 period, estimates in Boustan (2010) suggest that the median non-southern MSA grew by $58 \%$ between 1940 and 1970. Yet, while population growth in central cities and in suburbs was very similar before 1930, it was mostly concentrated in the suburban ring from 1940 to 2000 (Hobbs and Stoops, 2002).

Around 1910, for the first time in American history, blacks started to migrate to nonsouthern urban areas. For instance, the number of African Americans in the median (resp. average) city in my sample increased from 3,245 (resp. 15,335) to 7,779 (resp. 42,215) between 1910 and 1930. While in 1910 international (most often European) immigrants accounted for a relevant share of the population in many cities (Table A4), a white-black racial dichotomy was absent before the Great Migration, but rapidly entered the public domain, possibly influencing the assimilation of European immigrants between 1910 and 1930 (Fouka et al., 2018).

Rising racial diversity might have affected city finances either by changing preferences for redistribution of the white majority or by imposing a negative fiscal externality due to lower whites' demand for housing in the central city, as discussed in Section 3 above. Consistent with a fiscal externality channel, a large literature has shown that, between 1910 and 1930, black in-migration to northern cities increased dramatically (racial) residential segregation and this was not just a mechanical effect of growing city size. In fact, Cutler et al. (1999) document that collective action by native whites was the main mechanism responsible for this pattern. ${ }^{15}$ Similarly, Shertzer and Walsh (2016) find that at least one third of the rise in residential segregation between 1910 and 1930 was due to whites' decision to leave

\footnotetext{
${ }^{13}$ Since data for 1920 were missing, I used the 1919 volume - results are robust to using 1921, but 1919 is preferable because 1921 data were not reported for several cities. I digitized PDFs for the relevant years, including also 1906, which is used below to perform some robustness checks.

${ }^{14}$ In the Financial Statistics of Cities, property values refer to the assessed valuation of property. The tax rate on $1,000 \$$ of such assessed value is also separately reported.

${ }^{15}$ Cutler et al. (1999) show that, even if blacks on average paid lower rents relative to whites, the whiteblack gap was significantly lower in more segregated cities.
} 
neighborhoods where black migrants were moving to.

The pre-1930 period is particularly appealing to investigate these issues because, until the Great Depression, US cities were responsible for the provision of public goods such as education, police, and spending on welfare or on infrastructure (e.g. roads, sewerage, etc.), while federal and state governments played only a marginal role (Monkkonen, 1988). Since federal and state transfers were very limited, cities had to independently raise funds to finance their expenditures. Furthermore, differently from today, it was very rare for political jurisdictions to overlap within the same city. That is, cities were independent fiscal units, and (local) public officials had substantial control over the collection and the allocation of public resources.

Local taxes represented the main source of revenues, with property taxes accounting for more than $90 \%$ of total tax revenues (Fisher, 1996). As shown in Table A5, tax revenues and spending per capita rose substantially between 1910 and 1930, moving, on average, from 15 to around 30 dollars. Both taxes and public expenses were higher in larger cities (Table A6), not only in absolute value, but also in per capita terms. As expected, the largest spending category was education, which accounted for 30\% (resp. 40\%) of the budget in 1910 (resp. 1930). During this period, the increase in the share of spending in education was compensated by a relative decline in the share of spending in fire and police as well as in roads and public infrastructures (Figure A2).

\section{$5 \quad$ Empirical Strategy}

In this section, I present the baseline estimating equation (Section 5.1), construct the instrument for black population (Section 5.2) and for the induced white outmigration (Section 5.3), and report first stage results (Section 5.4).

\subsection{Baseline Estimating Equation}

To study the effects of the Great Migration on tax revenues, public spending, and public debt, I stack the data for the three Census years 1910, 1920, and 1930, and estimate

$$
Y_{c r t}=X_{c r t}+\beta_{1} B_{c r t}+\beta_{2} W_{c r t}+u_{c r t}
$$

where $Y_{c r t}$ is the outcome for city $c$ in Census region $r$ in year $t ;{ }^{16} B_{c r t}$ and $W_{c r t}$ are, respectively, the number of blacks and whites living in city $c$ in year $t$; and $X_{c r t}$ includes

\footnotetext{
${ }^{16}$ When defining regions, I follow the Census classification.
} 
city and year by region fixed effects, as well as additional controls described in detail below (Sections 5.2 and 5.3). Standard errors are clustered at the MSA level. Coefficients $\beta_{1}$ and $\beta_{2}$ should be interpreted as the effect of 1,000 more blacks and whites respectively in the central city.

Following the literature, and in particular Boustan (2010) and Shertzer and Walsh (2016), I adopt a specification in levels for several reasons. First, using the fraction of blacks over city population would restrict the effect of a new black migrant moving in to be the same as the effect of a white resident moving out - a stark and, probably, unreasonable assumption in this context. Second, both the number of blacks and the number of whites in the central city are endogenous, and two separate instruments are needed.

In addition, as shown in Peri and Sparber (2011), a specification in levels performs well in Monte Carlo simulations of specification bias in displacement models. Since the white flight is one of the key channels through which black inflows may have affected city finances and public spending, it is important to minimize potential bias coming from mis-specification. Finally, using a specification in levels allows for direct comparisons of my results with those obtained in previous works on the white flight, and in particular Boustan (2010 and 2017) and Shertzer and Walsh (2016).

One possible remaining issue with a specification in levels is that it implicitly weighs larger cities more. To address this issue, in Section 7, I repeat the analysis by trimming the sample at the $1^{\text {st }}$ and $99^{\text {th }}$ and at the $5^{\text {th }}$ and $95^{\text {th }}$ percentiles of black population, and by controlling for interactions between year dummies and 1900 city and black population.

\subsection{Instrument for Black Population}

A priori, we may expect blacks to be attracted to cities with better job opportunities, or with more appealing tax-public spending bundles. Alternatively, African Americans may settle in otherwise declining cities, where house prices were lower. In either case, OLS estimates of (1) will likely be biased. To reduce such endogeneity concerns, I instrument the location decision of black migrants using a version of the "shift-share" instrument commonly adopted in the immigration literature (Card, 2001). ${ }^{17}$

Specifically, I first estimate outmigration from each southern state for each decade using the forward survival method (Gregory, 2005). ${ }^{18}$ Using data for the United States as a whole, survival ratios were computed for each age-sex-race group and were then used to estimate

\footnotetext{
${ }^{17}$ A very similar approach is used by Boustan (2010) and Shertzer and Walsh (2016) for the second and for the first wave of the Great Migration respectively.

${ }^{18}$ Before 1940, no dataset on US internal migration exists, and so migration rates must be estimated (Shertzer and Walsh, 2016). For robustness, I compared my measure of estimated outmigration with that computed in Lee et al. (1957), and the two were very similar.
} 
net migration from each southern state (for each group). Next, outmigration flows are apportioned to northern cities depending on the share of southern born African Americans from each state living in each city in 1900. Formally, the number of blacks in the central city, $B_{\text {crt }}$, is instrumented with

$$
Z_{c r t}=\sum_{j \in \text { South }} \alpha_{j c}^{1900} O_{j t}
$$

where $\alpha_{j c}^{1900}$ is the share of blacks born in southern state $j$ residing in the non-South who were living in northern city $c$ in 1900, and $O_{j t}$ is the number of African Americans leaving state $j$ between $t-10$ and $t .^{19}$

The instrument constructed in equation (2) exploits two sources of variation. First, cross-sectional variation in settlements of blacks born in different southern states and living in different northern cities in $1900, \alpha_{j c}^{1900}$. Second, time-series variation in black outflows from different states over time, $O_{j t}$. In what follows, I describe the potential threats to the identifying assumptions behind each of these two sources of variation, and explain how I deal with them in my analysis.

\subsubsection{Initial Black Shares and Identifying Assumptions}

The location decision of early black migrants, and thus their initial settlements across northern cities, was strongly influenced by the railroad network. For example, as noted in Grossman (1989), "the first [black migrant from Mississippi] to leave for Chicago probably chose the city because of its position at the head of the Illinois Central". The Illinois Central was also connecting a number of southern railroads to northern hubs in Missouri and Illinois (Black et al., 2015). This, in turn, shaped the early migration patterns of blacks from e.g. Alabama to Chicago or St. Louis. ${ }^{20}$ For blacks born in Mississippi or Alabama it was much harder to reach Philadelphia, or even a hub like New York City - these cities were instead easier to reach from Florida. The stability of train routes, together with the process of chain migration, made early settlements highly persistent: over time, migrants tended to move where other migrants from the same county (or state) had moved in the past (see, among others, Wilkerson, 2010).

Figure 4 plots the share of southern born blacks from selected states living in a number of northern cities in 1900, and confirms visually that there was indeed large variation across

\footnotetext{
${ }^{19}$ I consider cities where $\alpha_{j c}^{1900}$ is above 0.005 for at least one southern state. Results are not sensitive to the choice of this threshold.

${ }^{20}$ Migration from Alabama to Chicago and St. Louis was largely facilitated by the presece of the $M o$ bileEGOhio (which later became the Gulf, MobileEOhio) and its intersection with the Illinois Central.
} 
both sending and receiving places. For instance, more than $10 \%$ of black migrants from Mississippi were living in Chicago in 1900, while much fewer of them were living in either New York or Philadelphia. On the other hand, while New York City hosted a very large community of blacks born in Florida, less than $5 \%$ of them were living in either St. Louis or Kansas City (MO).

The key assumption behind the cross-sectional variation exploited by the instrument is that cities receiving more blacks (from each southern state) before 1900 must not be on differential trends for the evolution of public spending and government finances in subsequent decades. ${ }^{21}$ This assumption would be violated if state level outmigration was influenced by cross-city pull factors systematically related to the origin state of 1900 settlers. For example, in the 1920s, outmigration rates were higher from Alabama than from Texas. The exclusion restriction requires that this was not happening because cities that in 1900 had attracted more migrants from Alabama were growing more than cities where more blacks from Texas had moved to before 1900. To indirectly address this concern, in Section 7, I perform two placebo exercises, including a formal test for pre-trends, and repeat the analysis interacting year dummies with a number of pre-migration city characteristics.

Another potential threat to the identifying assumption is that, by construction, the instrument predicts larger black in-migration to cities with relatively more black residents in 1900. While city fixed effects control for any time-invariant difference between cities, they do not address the possibility that places with a larger fraction of blacks in 1900 simultaneously attracted more migrants and experienced differential changes in e.g. government finances in subsequent decades. A related concern is that cities closer to the South were likely to receive more migrants in 1900 (Collins and Wanamaker, 2015) both in the OLS and when using 2SLS, and may have differed from other northern cities, e.g. because of their industry mix.

To deal with these issues, in my most preferred specification, I augment the vector of controls, $X_{c r t}$, interacting year dummies with the 1900 fraction of blacks and with city geographic coordinates. This set of interactions implies that the effects of black migration are identified exploiting variation only in the (southern state) composition of African Americans' enclaves across cities, holding constant the size of their black populations and their geographic location. ${ }^{22}$

\footnotetext{
${ }^{21}$ See also Goldsmith-Pinkhan et al. (2018) for a formal discussion of Bartik instruments - a class of instruments that include the shift-share used in my paper.

${ }^{22}$ As discussed in Section 7, results are also unchanged when interacting year dummies with 1900 city and black population, as well as with several other city characteristics.
} 


\subsubsection{Predicting Black Outflows with Push Factors}

Even if early settlements were as good as randomly assigned, one remaining concern is that black outflows from each southern state, $O_{j t}$, might have been differentially affected by specific, time-varying shocks in northern destinations. To deal with this potential threat, as in Boustan (2010), I construct a modified version of the instrument in (2) by replacing $O_{j t}$ with predicted outmigration. Specifically, in a "zeroth stage", I start by estimating:

$$
\operatorname{mig}_{s j t}=\alpha+\gamma \text { Push }_{s j t-10}+e_{s j t}
$$

where $m i g_{s j t}$ is the net black migration rate from county $s$ in southern state $j$ between $t$ and $t-10$. Since contemporaneous county characteristics might be themselves affected by migration occurring during a decade, I use beginning of decade county "push factors",

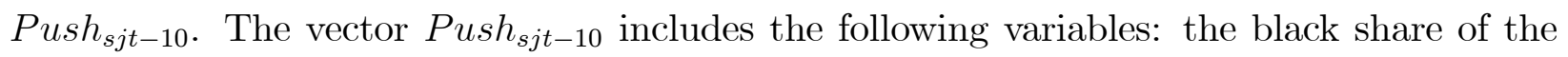
population; the share of the population living in rural areas; the share of land cultivated in cotton; and an indicator for the arrival of the boll weevil in the previous decade. Table A7 in the appendix presents results for equation (3).

Consistent with the historical evidence (e.g. Boustan, 2017), a higher black share and a higher fraction of the population living in rural areas are associated with larger black departures during the subsequent decade. Table A7 also shows that counties with a larger share of land cultivated in cotton were more likely to attract blacks between 1900 and 1920, but this pattern was reversed during the 1920-1930 decade. Indeed, after 1920, cotton mechanization began to spread around the South, reducing demand for black labor in agriculture and increasing incentives to migrate northward (Wright, 1986). Finally, in line with findings in Collins and Wanamaker (2015), the arrival of the boll weevil is significantly associated with black outflows only for the 1920-1930 decade. ${ }^{23}$

After estimating (3), I compute predicted migration flows from each county by multiplying the fitted values from (3) with the county initial black population. Finally, I aggregate these flows to the state level to obtain the predicted number of blacks leaving each southern state $j$ in each decade, $\hat{O}_{j t}$. I then replace $O_{j t}$ with $\hat{O}_{j t}$ in $(2)$ to derive the (push-factors induced) predicted number of blacks moving to city $c$ in year $t$. By construction, this (predicted) measure of black outmigration from the South is orthogonal to any specific shock occurring in the North. Moreover, by exploiting southern shocks to agricultural conditions, this instrument is less likely to suffer from the problem of high serial correlation in migration

\footnotetext{
${ }^{23}$ Results are very similar when including only a subset of the push factors used in (3), or when adding additional controls such as the share of a county cultivated with tobacco, the presence of railroads, or average farm values. Coefficients in Table A7 also remain very similar when estimating (3) including (southern) state fixed effects.
} 
patterns between sending and receiving areas - a possible concern for standard shift-share instruments (Jaeger et al., 2018). ${ }^{24}$

\subsection{Instrument for the White Flight}

When estimating (1), it is not enough to have an instrument for black in-migration, since whites often reacted to the inflow of African Americans by leaving central cities and relocating to the suburbs (Boustan, 2010; Shertzer and Walsh, 2016). To account for the white flight, I construct a second instrument by interacting predicted black inflows, $Z_{\text {crt }}$, with geographic characteristics of the area surrounding central cities that arguably increased the costs faced by whites when moving to the suburbs and commuting back and forth from the suburbs to the city. ${ }^{25}$

The intuition behind my strategy is that whites were induced to leave the central city by black arrivals (Boustan, 2010), but their ability to do so depended on MSA or city characteristics, like availability of land. In places with less available land (e.g. due to water, mountains, etc.), moving out was more expensive, because of higher rents and house prices (Saiz, 2010), or higher commuting costs. For this reason, one would expect the white flight to be lower in places surrounded by less friendly geography, other things being equal.

Specifically, I consider the fraction of the area around central cities: $i$ ) with slope above 15\% (to proxy for hills, as in Saiz, 2010); ii) occupied by lakes and oceans; and iii) occupied by rivers and streams. Data used to compute these measures were taken from USGS and from Saiz (2010). ${ }^{26}$ Following Saiz (2010), each variable was constructed using the area of a circle drawn around the central city with a $50 \mathrm{~km}$ radius. As a robustness check, I experimented with radii of different size, and results always remained similar.

To reduce concerns that geography can have a direct effect on city-level outcomes, when constructing geographic variables in $i$ to $i i i$, I exclude the area corresponding to the central city. This should also increase the confidence that I only exploit variation in the cost of suburbanization induced by suburban (rather than urban) geography. ${ }^{27}$ Formally, collecting the aforementioned geographic features in a vector, $R_{c r}$, the instrument for white population

\footnotetext{
${ }^{24}$ Note, also, that this was really the first episode of mass migration of blacks to the US North, and so my estimates are unlikely to suffer from any problem related to persistence or lagged effects of previous migration flows.

${ }^{25}$ Before the 1960s, most jobs remained concentrated in central cities, and so suburban residents had to commute to the inner city for work every day (Jackson, 1985).

${ }^{26}$ For elevation, I used Digital Elevation Model (DEM) at 90-square meter cell grids (available at http://www.cgiar-csi.org/data/srtm-90m-digital-elevation-database-v4-1). Data on rivers and streams were collected from http://water.usgs.gov/GIS/dsdl/ds240/, while Albert Saiz kindly shared with me data on oceans and lakes.

${ }^{27}$ Results are equivalent when using 1910 or 1930 city area.
} 
in (1) is given by the interaction $\left(Z_{c r t} \times R_{c r}\right)$, and the two first stage equations, for $B_{c r t}$ and $W_{\text {crt }}$, are

$$
\begin{gathered}
B_{c r t}=X_{c r t}+\delta_{1}^{b} Z_{c r t}+\delta_{2}^{b}\left(Z_{c r t} \times R_{c r}\right)+u_{c r t}^{b} \\
W_{c r t}=X_{c r t}+\delta_{1}^{w} Z_{c r t}+\delta_{2}^{w}\left(Z_{c r t} \times R_{c r}\right)+u_{c r t}^{w}
\end{gathered}
$$

\subsubsection{Validity of the Instrument}

The main concern on the validity of the instrument just described is that geography may have direct effects on house prices, or on blacks' settlement patterns. For instance, in more hilly MSAs, house prices are likely to be higher (Saiz, 2010). This, in turn, may affect both the location decision of black migrants and government finances. As shown in (5), however, the white flight is identified only out of the interaction term between (predicted) black in-migration and geography. Hence, any direct effect of geography on either second stage outcomes or settlement patterns is controlled for by the inclusion of fixed effects, as long as this is constant over time.

One possible remaining concern is that geography may have a time varying, city-specific, effect on outcomes. In particular, by limiting land available for the construction of new buildings, hills and water bodies will mechanically increase house prices as cities receive more migrants. This is because, with immigration, cities surrounded by geographic obstacles tend to become more densely populated, thereby increasing house prices. Another possible story is that, over time, mountains and oceans become valuable amenities, in turn affecting the trend in house values of different cities differently. To deal with these and similar concerns, the vector of controls $X_{c r t}$ in (1) includes a full set of interactions between year dummies and dummies indicating the presence of hills, oceans, or lakes above different thresholds. ${ }^{28}$

As a further robustness check, I repeated my analysis using a different instrument for white population, obtained by interacting $Z_{c r t}$ with average January temperature - a measure commonly used in the literature to proxy for city-level amenities (Glaeser and Shapiro, 2003; Glaeser and Gyourko, 2005). As shown in Section 7 below, results are very similar when using this alternative instrument.

\footnotetext{
${ }^{28}$ In my baseline specification, I define the threshold at 5\%, but I experimented with higher or lower values to check the robustness of my results, which always remained very similar. The distribution of these geographic characteristics is highly skewed. For instance, 22 of the 42 cities in my sample are not surrounded by hills or oceans (implying that the median is 0 ), but the 75 th percentile of the distribution of e.g. the lakes and oceans share of suburban area is as high as 20\%. There are 15 (resp. 19) cities where the share of the suburban area with slope above $15 \%$ (resp. occupied by lakes or oceans) is higher than five percent.
} 


\subsection{First Stage}

Table 3 estimates first stage equations (4) and (5). In column 1, I investigate the relationship between predicted black inflows, $Z_{\text {crt }}$ in (2), and actual black population, $B_{c r t}$, controlling for city and year by region fixed effects. There is a strong and significant correlation between black population and the instrument, while the F-stat is well above conventional values. The magnitude of the coefficient is smaller than that in Boustan (2010), but very similar to that in Shertzer and Walsh (2016) and in Fouka et al. (2018) for neighborhoods and MSAs respectively.

Next, columns 2 and 3 add interactions between predicted black migration and geography, $Z_{c r t} \times R_{c r}$. The coefficient on predicted black migration in the first stage for blacks (column 2) remains strongly significant. In the first stage for whites (column 3), predicted black migration is negatively correlated with white population, consistently with findings in Boustan (2010) and Shertzer and Walsh (2016), even though the point estimate is not statistically significant. More importantly, all interactions between $Z_{\text {crt }}$ and geography have the positive expected sign: in cities surrounded by less friendly geography, the white flight induced by black arrivals was less pronounced. The interaction between $Z_{c r t}$ and lakes and oceans is always highly significant, while that between hills and rivers is always positive, but its significance varies depending on the controls included in the regression. As in column 1, the F-stat and the partial AP F-stats for the joint significance of instruments in each first stage (reported at the bottom of the Table) are above conventional levels.

A similar pattern appears also when including interactions between year dummies and geography (columns 4 and 5), even though the coefficient on predicted black inflows in the first stage for whites becomes substantially smaller (in absolute value). Figure 5 confirms visually the strong relationship between actual and predicted black population, by plotting the graphical analogue of column 4. Finally, columns 6 and 7 replace the instrument constructed using actual black outmigration with that predicted exploiting only southern push factors. While the point estimate in column 6 is smaller than in columns 2 and 4 , it nonetheless remains statistically significant. Moreover, when focusing on column 7 , where the dependent variable is the number of whites in the central city, the direct effect of (predicted) black inmigration is negative and insignificant, whereas its interaction with all geographic features is always positive and statistically significant. ${ }^{29}$

In Table A8, I further test the robustness of results presented above. Columns 1 to 6 re-estimate (4) and (5) by dropping cities with each of the three geographic variables (oceans and lakes; hills; rivers) above the 95th percentile, to check that results reported in Table 3

\footnotetext{
${ }^{29}$ Figure A3 presents the residual scatterplot for specification estimated in column 6: reassuringly, it closely resembles the pattern displayed in Figure 5.
} 
are not driven by cities with extreme values of geography. ${ }^{30}$ Reassuringly, coefficients remain very similar to those in my baseline specification. In columns 7 and 8 , I show that results are not significantly affected when using a $30 \mathrm{~km}$ (rather than a $50 \mathrm{~km}$ ) radius to construct the geographic variables included in $R_{c r}{ }^{31}$

Overall, both the instrument for black population and that for the white flight - obtained by interacting predicted black inflows with geography - are strongly correlated with the corresponding endogenous regressors, and this relationship appears to be robust to different specifications.

\section{Results}

In this section, I study the effects of the Great Migration on tax revenues, public spending, and public debt in northern cities. The inflow of African Americans lowered house prices, and generated a negative fiscal externality. Unable or unwilling to raise tax rates, cities cut public spending and raised debt in order to meet a tighter budget constraint. Spending cuts were larger in education, where inter-racial interactions are probably more salient, suggesting that racial diversity might have lowered whites' utility from the consumption of public goods.

\subsection{Tax Revenues, Tax Rates, and Property Values}

In Table 4, I begin by analyzing the impact of the Great Migration on tax revenues, tax rates, and property values. I report OLS and 2SLS estimates in Panels A and B respectively, and the KP and the AP F-stats at the bottom of the table. In columns 1 and 2, the dependent variables are total and property tax revenues per capita, and the vector of controls, $X_{c r t}$, only includes city and year by region fixed effects. Both OLS and 2SLS coefficients on black population are negative and highly significant. Consistently with blacks selecting more prosperous cities, which likely had sounder government finances, OLS estimates are smaller (in absolute value) than 2SLS ones, even though the two are not statistically different from each other. The coefficients on white population are instead positive, but an order of magnitude smaller than those on blacks.

Column 3 replicates column 2 now including in $X_{c r t}$ also the full set of interactions between year dummies and the 1900 fraction of blacks, city coordinates, and geography. Results are barely affected, and the main message is unchanged: the inflow of African Americans had

\footnotetext{
${ }^{30}$ Columns 1-2 (3-4; 5-6) omit cities with values for oceans and lakes (hills; rivers) above the 95th percentile.

${ }^{31}$ The only difference with Table 3 is that the KP F-stat becomes lower. However, the partial F-stats remain well above conventional levels, and the significance of the individual coefficients is not substantially affected.
} 
a strong, negative effect on tax revenues per capita of northern cities. As discussed above, a negative relationship between black arrivals and tax revenues can be due to either lower tax rates, reflecting a reduction in demand for redistribution, or falling property values, induced by the white flight (or both). Columns 4 to 7 investigate the two channels separately. The inflow of African Americans did not significantly affect tax rates (column 4), but had a strong and negative effect on property values (columns 5 to 7 ). This pattern is visually depicted in Figure 6, which plots the residual bin-scatterplot for the reduced form relationship between predicted black inflows and, respectively, property values over 1900 population (left-panel) and tax rates (right-panel).

Since there is no obvious way to define the tax base, in Table 4, I scale property values by, respectively, 1900, 1910, and contemporaneous population. In all cases, results point in the same direction: black in-migration lowered house values in receiving cities, driving down tax revenues and imposing a negative fiscal externality. Importantly, results are very similar - if anything larger in magnitude - when using the instrument for black inflows obtained by predicting outmigration with southern push factors (Table A9) ${ }^{32}$

To gauge the size of these effects consider that, between 1910 and 1930, the median city in my sample, Omaha (NE), received more than 6,000 southern born blacks. 2SLS coefficients on black population in columns 3 and 5 (Panel B) imply that, for this city, the Great Migration lowered per capita property tax revenues and property values by respectively $6 \%$ and $8 \%$ relative to their 1910 mean. These numbers are remarkably similar to the estimates in Boustan (2012), who finds that, during the 1970s, desegregation lowered urban house prices and rents by $6 \%$.

When interpreting my results and comparing them with those in Boustan (2010 and 2012), however, it should be kept in mind that, until 1930, cities were attracting and not losing population. Hence, the (negative) fiscal effects of the Great Migration estimated above likely reflect a combination of: $i$ ) actual departures of existing residents; and $i i$ ) a slowdown in migration to the central city of native whites living elsewhere. Prior to 1940, data on internal migration are not available. However, following Bandiera et al. (2017), I use the number of white household heads born in another state as a proxy for internal (white) migrants.

Figure A4 plots the residual scatterplot of the relationship between predicted black inflows (x-axis) and the number of white household heads born in another state (y-axis). The steep, negative slope of the regression line suggests that the slowdown in internal migration was responsible for at least part of the reduction in whites' housing demand in central cities. ${ }^{33}$

\footnotetext{
${ }^{32}$ Section 7 below performs a large number of robustness checks to further corroborate the causal interpretation of black arrivals on city finances.

${ }^{33}$ Figure A4 partials out total MSA population, city and year by region fixed effects, and interactions
} 
In unreported results, I also studied the effects of black inflows on the share (rather than the number) of white household heads born in another state. In this case, the coefficient was negative but very close to zero, and not statistically significant, suggesting that both the white flight and lower in-migration of native whites reduced demand for housing in central cities.

Overall, results in Table 4 indicate that black inflows lowered house prices and imposed a negative fiscal externality on northern urban areas. Unable (or unwilling) to raise taxes, receiving cities may have been forced to cut spending and increase debt to meet a tighter budget constraint, as I show in the next two sections.

\subsection{Public Spending}

In Table 5, I investigate the effects of black in-migration on public spending per capita - total (column 1) and by category (columns 2 to 8$) \cdot{ }^{34}$ The inflow of blacks was associated with a significant reduction in per capita spending, which was larger for education (column 2) and outdoor poverty relief (column 8). ${ }^{35}$ When comparing coefficients of Table 5 , it immediately appears that spending cuts were not evenly distributed across categories. For instance, while spending on education fell by more than $6 \%$ relative to its 1910 mean, that on fire protection (column 4), roads (column 6), or charities and hospitals (column 7) was barely affected. ${ }^{36}$ Also, in contrast with findings in Alesina et al. (1999), black inflows had a negative, albeit quantitatively small, effect on spending for police (column 3). As for Table 4, also in this case results are unchanged when using predicted outmigration to instrument for changes in black population (Table A10).

To more directly test the possibility that black in-migration altered the allocation of the budget across categories, I computed spending shares by dividing each of the outcomes in columns 2 to 7 by total spending (column 1). Table 6 confirms the pattern that was already apparent in Table 5: black inflows had a negative and significant effect on the share of spending on education (column 1), police (column 2), and sewerage and garbage collection (column 4). Conversely, there is a positive relationship between the inflow of African Americans and the spending share on fire protection (column 3) and roads (column

between year dummies and: i) the 1900 fraction of blacks; ii) latitude and longitude. The regression coefficient is statistically significant at the $1 \%$ level, and implies that every predicted black arrival reduced the number of native whites born in another state by 0.8 - a sizable effect.

${ }^{34}$ As before, OLS and 2SLS results are reported in Panels A and B respectively.

${ }^{35}$ Spending on outdoor poverty relief was reported only for the 14 largest cities in my sample, and was collected separately from Geddes (1937), and not from the Financial Statistics of Cities. Due to the very limited sample size, column 8 only includes city and year by region fixed effects.

${ }^{36}$ Data on spending for charities and hospitals was not reported for San Diego in 1910, for Scranton in 1910 and 1920, and for Peoria in 1930. 
5), even though the latter is not statistically significant. ${ }^{37}$

One possible concern with the interpretation of results in Tables 5 and 6 , and with the reduction in spending on education in particular, is that they were due to changes in the demographic composition of northern cities induced by the Great Migration. To address this possibility, appendix Table A12 repeats the analysis scaling spending on education by the number of residents in schooling age (column 1) and enrolled in public schools (column 2). ${ }^{38}$ Again, there is a negative and significant relationship between black population and spending on education, which is quantitatively in line with that reported in Table 5.

Table A12 also shows that the inflow of African Americans did not lead to changes in the fraction of enrolled pupils (column 3), implying that lower spending on education resulted in fewer resources per student. Data limitations prevent me from investigating possible redistributional effects among northern residents by studying, for instance, if (whites') enrollment and resources shifted from public to private schools, or, more generally away from schools located in neighborhoods more affected by the inflow of blacks (Cascio and Lewis, 2012). Finally, in column 4, I show that, despite the fall in public spending on education, there was no significant decline in the share of literate whites. One possible reason for this is that, by 1930, almost all whites could write and read, and literacy is thus an excessively coarse proxy for education. ${ }^{39}$

\subsection{Municipal Debt}

While the Great Migration had a negative and significant effect on public spending per capita, the implied magnitude of coefficients in Table 5 is quantitatively smaller (in absolute value) than that in Table 4. Specifically, for the median city, 2SLS estimates imply that black arrivals lowered tax revenues by more than $6 \%$ relative to their baseline value. However, public spending fell only by approximately $2 \%$. One possible explanation for these patterns is that cities partly offset the fall in the tax base by raising debt. In Table 7, I directly test this idea, and show that the inflow of African Americans had a positive and significant effect on public debt per capita (column 1). Both gross and net debt went up, but black in-migration had a significant impact only on the latter (columns 2 and 3). Once again, Table A13 confirms that results are unchanged when instrumenting black population with predicted black in-migration constructed using southern push factors.

The magnitude of the 2SLS coefficient in column 1 (Panel B) implies that, in response

\footnotetext{
${ }^{37}$ See Table A11 for results obtained with the instrument constructed using southern push factors.

${ }^{38}$ Data on the number of students enrolled in public schools was missing for Seattle and Tacoma in 1930.

${ }^{39}$ Before 1940, the US Census did not collect finer measures of education, like the number of years of schooling. An alternative explanation for findings in column 4 of Table A12 is that the reduction in spending on education is unlikely to immediately affect literacy rates.
} 
to the Great Migration, the level of indebtedness of the median city in my sample rose by approximately 4\% relative to its 1910 level. Incidentally, this amount is close to the gap between the reduction in tax revenues and in public spending documented above, suggesting the existence of a causal link between changes in property taxes on the one hand and both public spending and debt on the other. Consistent with this conjecture, there is also a strong and positive relationship between the inflow of African Americans and the debt to tax revenues ratio (column 4), which increased by approximately 8\% relative to its 1910 value because of black in-migration.

One potential implication of findings in Table 7 is that, even if in the short run cities were able to partially cope with lower tax revenues by raising debt, over time this strategy may have proven unsustainable. In particular, depressed revenues and higher (and growing) levels of debt may have contributed to the distressed financial conditions and the heavy interest burdens that many US central cities systematically experienced in the past 40 years. Evaluating the long run effects of the Great Migration goes beyond the scope of this paper, but results in this section are consistent with Derenoncourt (2017), who shows that, today, intergenerational mobility is lower in MSAs that received larger inflows of African Americans between 1940 and 1970 .

\subsection{Unpacking the Effects of Black Migration}

\subsubsection{Demand for Public Goods or Fiscal Externality?}

The inflow of African Americans had a negative and significant effect on tax revenues and public spending in northern cities. As shown in Tables 5 and 6, the reduction in public expenditures was not evenly distributed across categories, and was larger in education and in outdoor poverty relief. This observation is consistent with the idea that higher racial heterogeneity altered whites' demand for public goods and their preferences for redistribution (Alesina et al., 1999; Dahlberg et al., 2012). When deciding how to allocate the budget, (white) voters chose to undertake larger spending cuts in categories where inter-racial interactions are likely to be particularly salient, like education. ${ }^{40}$

However, even if the budget allocation decision was affected by black inflows, I argue that the reduction in public spending was triggered more by a fiscal externality than by lower demand for public goods. One interpretation of previous results is that the Great Migration reduced property values in receiving cities which, unable (or unwilling) to increase tax rates, were forced to cut spending and increase debt to deal with a tighter budget constraint.

\footnotetext{
${ }^{40}$ The large drop in public spending on education is also in line with the existing literature on racial diversity and school choice in the US (e.g. Baum-Snow and Lutz, 2011; Cascio and Lewis, 2012).
} 
Note that this hypothesis has two testable implications. First, if the negative effect of black in-migration on property values was due to lower demand for housing in central cities by whites, the coefficient on black inflows should increase in absolute value when omitting white population. Second, the effects of the Great Migration should be larger in cities with lower population growth, as white departures are more likely to increase the number of vacant units and depress house prices there. On the contrary, urban decline should be more contained (or absent) in booming cities, where the white flight is less likely to increase the vacancy rate.

In Table 8, I test the first implication, and re-estimate the effects of black in-migration on tax revenues, property values, and public spending without controlling for white population. Panels A and B present 2SLS results obtained from the baseline and the "push factors" instruments respectively. ${ }^{41}$ In both cases, the coefficient on black population is larger than that estimated in my baseline specification (Tables 4 and 5), and this difference is particularly pronounced for property values (column 4). These patterns support the idea that the negative effect of black in-migration on city finances operated through the housing market, and in particular through whites' (re)location decisions.

Next, I split the sample between high and low growth cities, and interact the main effect of black population with a dummy equal to one if the 1910-1930 population growth rate is above the median growth rate of the cities in my sample (0.48). I start by testing if the Great Migration had a significantly different effect on property values for high and low growth cities (Table 9, columns 1 and 2). ${ }^{42}$ 2SLS results suggest that, again consistent with the hypothesis advanced above, the fall in property values was significantly larger in cities with population growth below the median. To provide further, corroborating evidence, in columns 3 to 6 of Table 9, I make use of historical data from local newspapers, and search for the frequency of specific terms that should be indicative of urban decay and losses in property values. ${ }^{43}$ Specifically, I consider the following terms: in column 3, I start by searching for neutral terms "black" and "blacks"; then, in columns 4 to 6, I consider, respectively, the terms "decay", "ghetto", and "segregation". To adjust for the fact that larger cities have larger newspapers circulation, the frequency of each term is scaled by the total number of articles appearing in a city in a decade. ${ }^{44}$

Two main results stand out. First, black inflows increased significantly not only the frequency of neutral terms "blacks" and "black" (column 3), but also that of words "decay"

\footnotetext{
${ }^{41}$ In this case, I follow Boustan (2010) and separately control for total MSA population.

${ }^{42}$ As for Table 8, Panels A and B report 2SLS results from the baseline and the "push factors" instruments respectively.

${ }^{43}$ The data were collected by D'Amico e Tabellini (2017) through the website newspapers.com, and are available for 31 of the 42 cities in my sample.

${ }^{44}$ To ease the interpretation of coefficients, these relative frequencies are multiplied by 100.
} 
(column 4), "ghetto" (column 5), and "segregation" (column 6), which might indicate (white) residents' perceptions of housing conditions in a city. Second, this effect was significantly lower in high-growth cities, where, as noted above, the negative fiscal externality operating through the housing market should be less pronounced.

\subsubsection{Further, Suggestive Evidence on the White Flight}

In Table A14, I provide additional evidence that the Great Migration increased whites' demand for suburbanization. First, the growth in the number of dwellings (scaled by 1900 population) was lower in cities that received more blacks (column 1). ${ }^{45}$ This pattern is consistent with Boustan (2010), who finds that the second wave of the Great Migration slowed down the construction of new housing units and increased the number of vacant dwellings in northern cities. Second, in places receiving more blacks, the increase in city-area was more limited (column 2). As explained in Jackson (1985), during this period, most cities expanded their boundaries by annexing neighboring towns and villages. If whites moved to the suburbs so as not to pay for and share public goods with blacks, they should have also tried to resist annexation by central cities. Findings in column 2 are indeed consistent with this idea.

Next, in columns 3 to 5 , I study if the first wave of the Great Migration increased demand for suburbanization by analyzing its effect on the construction of highways since the 1950s (Baum-Snow, 2007). The main regressors of interest are the 1910-1930 (instrumented) change in black and white population, while the dependent variable is the number of highway rays running through the central city planned in the Federal Highway Act of 1944 (column 3) and actually built between 1950 and, respectively, 1970 (column 4) and 2000 (column 5). ${ }^{46}$ There is a positive and significant relationship between 1910-1930 black migration and the subsequent planning and construction of highways. While only suggestive, these results are consistent with the idea that black inflows increased demand for suburbanization, ultimately leading to the construction of more highways in places where incentives to leave the central city were higher.

Finally, in columns 6 and 7, the 1940-1970 change in the number of special districts and municipalities in the MSA (collected from the Census of Governments) is regressed against the 1910-1930 (instrumented) change in black and white population. ${ }^{47}$ As discussed

\footnotetext{
${ }^{45}$ Data on the number of dwellings was missing for Milwaukee in 1930.

${ }^{46}$ As in all previous Tables, these regressions also account for possible differential trends associated with the variables included in $X_{c r t}$ above, i.e., 1900 fraction of blacks; latitude and longitude; and geography. Data on highways were taken from Baum-Snow (2007), and were not available for Bridgeport (CT).

${ }^{47}$ Data limitations prevent me from examining the contemporaneous effect of black migration on this outcome, since the number of local governments at the county level was first reported in the Census of
} 
in Alesina et al. (2004), racial heterogeneity may increase whites' desire for political fragmentation and, in turn, the number of local governments (see also Burns, 1994). Consistently with this idea, the 1910-1930 inflow of African Americans is positively correlated with the subsequent change in the number of special districts and municipalities. These findings are also in line with Boustan (2017), who argues that many whites were leaving central cities not necessarily to avoid inter-racial interactions in the housing or in the labor market, but in order to avoid sharing public goods with African Americans.

\section{Robustness Checks}

In this section, I perform several robustness checks. First, I test for pre-trends and perform a placebo exercise to assess the validity the instrument for black migration (Section 7.1). Second, I document that results are robust to interacting year dummies with a number of 1900 city characteristics that may be correlated with pre-migration blacks' settlements and with changes in the economic and political environment (Section 7.2). Finally, in Section 7.3, I replicate the analysis trimming the sample, and instrumenting white population with the interaction between predicted black in-migration and average low January temperature, a variable often used in the literature to proxy for city-level amenities (Glaeser and Shapiro, 2003; Glaeser and Gyourko, 2005).

\subsection{Placebo Checks and Pre-Trends}

As discussed in Section 5.2, one possible concern with the instrument for black population, $Z_{c r t}$ in (2), is that early migrants settled in booming northern cities that continued to grow more also in subsequent decades. I already showed that all results are robust to using a version of the instrument constructed with predicted black outmigration from the South that exploits only variation orthogonal to conditions in northern cities. In what follows, I present a set of placebo checks to further support the validity of my empirical strategy.

First, I predicted white inflows by estimating outmigration from each southern state for each decade using the forward survival method, and then assigning such migration flows to northern cities according to 1900 blacks' settlements, $\alpha_{j c}^{1900}$ in (2). Results of this test are reported in Figure A5, which plots the relationship between white population in northern cities and southern whites' in-migration predicted using 1900 blacks' settlements. Reassuringly, there is no relationship between white population and white in-migration from the South, predicted using African Americans' enclaves. While Figure A5 provides only indirect

Governments of 1942. 
evidence on the validity of the instrument, it is reassuring to find that blacks' settlements have predictive power only for black (Figure 5), and not for white inflows to northern cities.

Next, in Tables A15 and A16, I formally test if pre-migration changes in city socioeconomic conditions predict subsequent changes in (instrumented) black in-migration. In column 1 of Table A15, I address the possibility that the instrument for black migration may be correlated with the 1900-1910 change in European immigration. This would be problematic because the drop in European immigration after 1915 was an important determinant of the Great Migration (Collins, 1997), and one may thus be worried that results presented above are at least in part driven by changes in the number of international immigrants. However, there is no correlation between the 1900-1910 change in European immigration and the 1910-1930 change in predicted black migration.

Similarly, columns 2 to 5 show that the 1900-1910 growth in industrial production, establishment size, and wages in manufacturing is not correlated with 1910-1930 predicted black in-migration. This is another important check, since most African Americans living in the North were employed in manufacturing, and one may be worried that early movers selected cities where this sector was booming, in turn threatening the validity of the instrument constructed in Section 5.2.

Finally, in Table A16, I regress pre-period changes in the key outcomes considered in Section 6 against 1910-1930 predicted black in-migration and white population. In Panel $\mathrm{B}$, the dependent variable is the 1906-1910 change in per capita: total and property tax revenues (columns 1 and 2); property values (column 3); and total and education spending (columns 4 and 5). ${ }^{48}$ To ease comparison with findings reported in Section 6, Panel A of Table A16 reports my baseline specification. The picture that emerges is reassuring: while there is a positive and significant correlation between the 1906-1910 change in tax revenues and the 1910-1930 change in white population (columns 1 and 2), there is no relationship between changes in pre-migration outcomes and subsequent changes in black inflows. Also, and importantly, magnitudes are very different from those in the baseline specification.

\subsection{Pre-Migration City Characteristics and Differential Trends}

Yet another concern is that the characteristics of cities that attracted black migrants before 1900 persisted over time, and had confounding effects on migration patterns as well as on the evolution of economic and political conditions. My most preferred specification already controls for interactions between year dummies and the 1900 fraction of blacks, latitude and longitude, and geography. However, in Tables A17 and A18, I more systematically check

\footnotetext{
${ }^{48}$ When performing this exercise, 1906 is used because this is the first year in which the Financial Statistics of Cities collected data in a way that is comparable to subsequent years.
} 
that interacting year dummies with additional socio-economic variables does not alter any of the main findings presented in Section 6.

In Table A17 (Panel A), I start by replacing latitude and longitude with a measure for distance from the South, and results remain very close to those from my baseline specification. ${ }^{49}$ Next, as noted in the previous section, cities that received more European immigrants between 1870 and 1915 may have attracted more blacks once the Immigration Acts of the 1920s were passed (Collins, 1997), and, at the same time, may have experienced differential changes in tax revenues or public goods provision (Tabellini, 2018). For this reason, in Panel B of Table A17, I include in $X_{c r t}$ interactions between year dummies and the 1900 fraction of Europeans. Finally, in Panel C of Table A17, I replace the interaction between year dummies and the 1900 share of blacks with that between year dummies and both city and black population. Reassuringly, in all cases, remain in line with those reported in the main text

In Table A18, I further check that results are robust to interacting year dummies with, respectively, skill ratios, value added by manufacture, and the share of employment in manufacture in 1900 (Panels A, B, and C). Reassuringly, also in this case coefficients are stable across specifications, and results are barely affected.

\subsection{Trimmed Sample and Alternative Instrument}

As discussed in Section 5.1, one potential remaining concern is that a specification in levels, as the one used in my paper (as well as in Boustan, 2010, and in Shertzer and Walsh, 2016), implicitly weighs larger cities more. To deal with this issue, following Shertzer and Walsh (2016), I repeated my analysis by trimming the sample at the $1^{\text {st }}$ and $99^{\text {th }}$ and the $5^{\text {th }}$ and $95^{\text {th }}$ percentiles of black population. Results are reported in Table A19 (Panels A and B respectively). ${ }^{50}$ Not surprisingly, the KP and AP F-stats are somewhat lower than in the baseline specification.

However, second stage results are in line with those reported in Section 6. The only difference appears to be in column 3, where the dependent variable is the property tax rate. Yet, standard errors are so large that the coefficient in either Panel A or Panel B is not statistically different from that in column 4 of Table 4 . As a further check, I also replicated Table A19 dropping, in turn, each of the five largest cities in my sample (New York, Chicago, Philadelphia, Detroit, and Los Angeles), and findings were not significantly affected. Overall, while one cannot completely rule out the possibility that results may be somewhat driven

\footnotetext{
${ }^{49}$ Distance from the South was constructed by computing the distance between each northern city in my sample and the capital of the southern state that, by 1900, had sent more blacks to that city.

${ }^{50}$ Panels A and B omit, respectively, New York City and Duluth, and New York City, Philadelphia, Washington D.C., Duluth, San Diego, and Scranton.
} 
by the largest cities in my sample, Table A19 should reduce this concern.

As a final check, I repeated my analysis using a different instrument for the white flight. Specifically, when instrumenting $W_{c r t}$ in (1), I interacted predicted black inflows with average low January temperature, rather than with the geographic variables used above. ${ }^{51}$ As discussed in Glaeser and Gyourko (2005) among others, weather has been shown to affect residential decisions in the United States, and several papers have used it as a proxy for city-level amenities (e.g. Glaeser and Shapiro, 2003). Starting from this observation, I constructed an alternative instrument, interacting $Z_{c r t}$ with average low January temperature, to check whether findings in the paper are driven in some way by the geographic variables used in the baseline specification. Reassuringly, results, reported in Table A20, show that this is not the case.

\section{Conclusions}

Between 1915 and 1930, more than 1.5 million African Americans moved from the rural South to the urban North of the United States. I exploit this historical episode to study how the arrival of blacks, and the resulting increase in racial heterogeneity, affected government finances and public spending in northern cities. Instrumenting both black inflows and the induced white outflows, I find that in-migration of African Americans had a strong, negative effect on tax revenues, entirely due to declining property values. Unable or unwilling to raise tax rates, cities were forced to cut spending and raise debt to cope with a tighter budget constraint. While higher debt made it possible to only partially reduce public goods provision, this strategy may have proven unsustainable in the long run, contributing to the current financial distress of several US central cities.

Findings in this paper provide motivation for future work along several directions. First, I only focused on the contemporaneous effects of black in-migration, but a natural extension would be that of considering the medium to long run consequences of the Great Migration on both city finances and public goods provision. Second, it may be interesting to compare the Great Migration with other episodes of (im)migration experienced by the United States, such as the Mass Migration of Europeans between 1870 and 1915 or the more recent Hispanic immigration. Finally, it would be particularly informative for the current situation in both Europe and the US to investigate if the Great Migration fueled natives' backlash and favored the election of "anti-black" mayors, and if changes in public spending documented in my work were correlated with the identity of elected politicians in northern cities.

\footnotetext{
${ }^{51}$ Data on January average temperature for each city was collected from http://www.usclimatedata.com/climate/united-states/us.
} 


\section{References}

[1] Alesina, A., R. Baqir, and W. Easterly (1999). "Public Goods and Ethnic Divisions". Quarterly Journal of Economics, 114 (November), 1243-84.

[2] Alesina, A., R. Baqir, and C. Hoxby (2004). "Political Jurisdictions in Heterogeneous Communities". Journal of Political Economy 112, 348-96.

[3] Alesina, A., E. L. Glaeser, and B. Sacerdote (2001). "Why Doesn't the United States Have a European-Style Welfare State?" Brookings Papers Econ. Activity, 2, 187-278.

[4] Alesina, A. and E. L. Glaeser (2004). Fighting Poverty in the US and Europe: A World of Difference. Oxford University Press, Oxford UK.

[5] Allard, S. W. (2017). Places in Need: The Changing Geography of Poverty. Russell Sage Foundation.

[6] Bandiera, O., I. Rasul, M. Mohnen, and M. Viarengo (2017). "Nation-Building Through Compulsory Schooling During the Age of Mass Migration". Working Paper.

[7] Baum-Snow, N. (2007). "Did Highways Cause Suburbanization?". The Quarterly Journal of Economics, 122(2), 775-805.

[8] Baum-Snow, N., and B. F. Lutz (2011). "School Desegregation, School Choice, and Changes in Residential Location Patterns by Race". American Economic Review, 101(7), 3019-3046.

[9] Beach, B. and D. Jones (2017). "Gridlock: Ethnic Diversity in Government and the Provision of Public Goods." American Economic Journal: Economic Policy, 9(1), 112136.

[10] Black, D. A., S. G. Sanders, E. J. Taylor, and L. J. Taylor (2015). "The Impact of the Great Migration on Mortality of African Americans: Evidence from the Deep South." American Economic Review, 105(2), 477-503.

[11] Boustan, L. P. (2009). "Competition in the Promised Land: Black Migration and Racial Wage Convergence in the North, 1940-1970". The Journal of Economic History, 69(3), 756-783.

[12] Boustan, L. P. (2010). "Was Postwar Suburbanization 'White Flight?' Evidence from the Black Migration." Quarterly Journal of Economics, 125(1), 417-443. 
[13] Boustan, L. P. (2012). "School Desegregation and Urban Change: Evidence from City Boundaries." American Economic Journal: Applied Economics, 4(1), 85-108.

[14] Boustan, L. P. (2013). "Local public goods and the demand for high-income municipalities." Journal of Urban Economics, 76, 71-82.

[15] Boustan, L. P. (2017). Competition in the Promised Land: Black Migrants in Northern Cities and Labor Markets. Princeton University Press.

[16] Boustan, L. P., M. E. Kahn, and P. W. Rhode (2012). "Moving to Higher Ground: Migration Response to Natural Disasters in the Early Twentieth Century." American Economic Review, 102(3), 238-244.

[17] Burns, N. (1994). The Formation of American Local Governments: Private Values in Public Institutions. Oxford: Oxford University Press.

[18] Card, D. (2001). "Immigrant Inflows, Native Outflows, and the Local Labor Market Impacts of Higher Immigration." Journal of Labor Economics, 19(1), 22-64.

[19] Card, D., C. Dustmann, and I. Preston (2012). "Immigration, Wages, and Compositional Amenities". Journal of the European Economic Association, 10, 78-119.

[20] Card, D., A. Mas, and J. Rothstein (2008). "Tipping and the Dynamics of Segregation". Quarterly Journal of Economics, 123 (1), 177-218.

[21] Cascio, E. U., and E. G. Lewis (2012). "Cracks in the Melting Pot: Immigration, School Choice, and Segregation". American Economic Journal: Economic Policy, 4(3), 91-117.

[22] Chay, K. and K. Munshi (2015). "Black Networks After Emancipation: Evidence from Reconstruction and the Great Migration". Working Paper.

[23] Clubb, J. M., W. H. Flanigan, and N. H. Zingale. "Electoral Data for Counties in the United States: Presidential and Congressional Races, 1840-1972". ICPSR08611-v1. Ann Arbor, MI: Inter-university Consortium for Political and Social Research [distributor], 2006-11-13. http://doi.org/10.3886/ICPSR08611.v1

[24] Collins, W. J. (1997). "When the Tide Turned: Immigration and the Delay of the Great Black Migration". Journal of Economic History, 57(3), 607-632.

[25] Collins, W. J., and M. H. Wanamaker (2014). "Selection and Income Gains in the Great Migration of African Americans." American Economic Journal: Applied, 6(1), 220-252. 
[26] Collins, W. J., and M. H. Wanamaker (2015). "The Great Migration in Black and White: New Evidence on the Selection and Sorting of Southern Migrants". The Journal of Economic History, 75(4), 947-992.

[27] Cutler, D.M., E.L. Glaeser and J.L. Vigdor (1999). "The Rise and Decline of the American Ghetto". Journal of Political Economy, 107, 455-506.

[28] Cutler, D.M., E.L. Glaeser and J.L. Vigdor (2008). "Is the Melting Pot Still Hot? Explaining the Resurgence of Immigrant Segregation". Review of Economics and Statistics, 90(3), 478-497.

[29] D'Amico, L. and M. Tabellini (2017). "Measuring Attitudes Towards Immigration Using Local Newspapers' Data and Congressional Speeches". Working Paper

[30] Dahlberg, M., K. Edmark, and H. Lundqvist (2012). "Ethnic Diversity and Preferences for Redistribution". Journal of Political Economy, 120(1), 41-76.

[31] Danielson, M. N. (1976). The Politics of Exclusion. New York: Columbia University Press.

[32] Derenoncourt, E. (2017). "Historical Origins for Intergenerational Mobility Differences across US cities Today". Working Paper.

[33] Dustmann, C., K. Vasiljeva, and A. Piil Damm (2016). "Refugee Migration and Electoral Outcomes". Discussion Paper Series, CDP 19/16.

[34] Fisher, G. W. (1996). The Worst Tax? A History of the Property Tax in America. Lawrence: University Press of Kansas.

[35] Fouka, V., S. Mazumder, and M. Tabellini (2018). "From Immigrants to Americans: Race, Status, and Assimilation During the Great Migration". Working Paper.

[36] Fryer R.G. and L. F. Katz (2013). "Achieving Escape Velocity: Neighborhood and School Interventions to Reduce Persistent Inequality". American Economic Review Papers and Proceedings, 103(3), 232-37.

[37] Geddes, A. E. (1937). Trends In Relief Expenditures, 1910-1935. Washington: U.S. Govt. Print. Off.

[38] Glaeser, E. L. and J. Gyourko (2005). "Urban Decline and Durable Housing". Journal of Political Economy, 113 (2), 345-375. 
[39] Glaeser, E. L., and J. M. Shapiro (2003). "Urban Growth in the 1990s: Is City Living Back?". Journal of Regional Science, 43(February), 139-65.

[40] Goldsmith-Pinkham, P., I. Sorkin, and H. Swift (2018). "Bartik Instruments: What, When, Why, and How." NBER Working Paper 24408.

[41] Gregory, J. N. (2005). The Southern Diaspora: How the Great Migrations of Black and White Southerners Transformed America. Chapel Hill: University of North Carolina Press.

[42] Grossman, J. R. (1989). Land of Hope: Chicago, Black Southerners, and the Great Migration. Chicago: University of Chicago Press.

[43] Haines, M. R. (2010). "Historical, Demographic, Economic, and Social Data: The United States, 1790-2002." ICPSR02896-v3. Ann Arbor, MI: Inter-university Consortium for Political and Social Research [distributor]. doi:10.3886/ICPSR02896.v3.

[44] Halla, M., A. F. Wagner, and J. Zweimuller (2017). "Immigration and Voting for the Far Right". Journal of the European Economic Association, Forthcoming.

[45] Hobbs, F. and N. Stoops (2002). "Demographic Trends in the 20th Century". U.S. Census Bureau, Census 2000 Special Reports, Series CENSR-4, U.S. Government Printing Office, Washington, DC.

[46] Hornbeck, R. and S. Naidu (2014). "When the Levee Breaks: Black Migration and Economic Development in the American South". American Economic Review, 104(3), 963-990.

[47] Jackson, K. T (1985). Crabgrass Frontier: The Suburbanization of the United States. Oxford University Press.

[48] Jaeger, D. A., J. Ruist, and J. Stuhler (2018). "Shift-Share Instruments and the Impact of Immigration." NBER Working Paper 24285.

[49] Katz, L. F. (2015). "Reducing Inequality: Neighborhood and School Interventions". Focus 31, 2, (Fall/Winter 2014-15), 12-17.

[50] Kneebone, E. (2017). "The changing geography of US poverty." Brookings Institutions, February 2017.

[51] Lange, F., A. L. Olmstead, and P. W. Rhode (2009). "The Impact of the Boll Weevil, 1892-1932." Journal of Economic History, 69(3), 685-718. 
[52] Luttmer, E. F. P (2001). "Group Loyalty and the Taste for Redistribution" Journal of Political Economy,109 (3), 500-528.

[53] Mayda A. M., G. Peri, and W. Steingress (2016). "Immigration to the US: A Problem for the Republicans or the Democrats?". NBER Working Paper 21941.

[54] Monkkonen, E. (1988). America Becomes Urban: The Development of U.S. Cities and Towns, 1780-1980. Berkeley: University of California Press.

[55] Nekby, L. and P. Pettersson-Lidbom (2017). "Revisiting the Relationship between Ethnic Diversity and Preferences for Redistribution: Comment". The Scandinavian Journal of Economics, 119(2), 268-287.

[56] Peri, G. and C. Sparber (2011). "Assessing Inherent Model Bias: An Application to Native Displacement in Response to Immigration." Journal of Urban Economics, 69(1), 82-91.

[57] Ruggles, S., M. Sobek, T. Alexander, C. A. Fitch, R. Goeken, P. Kelly Hall, M. King, and C. Ronnander (2010). Integrated Public Use Microdata Series: Version 4.0 [Machine-readable database]. Minneapolis, MN: The University of Minnesota.

[58] Saiz, A. (2010). "The Geographic Determinants of Housing Supply". Quarterly Journal of Economics, 125 (3), 1253-1296.

[59] Saiz. A. and S. M. Wachter (2011). "Immigration and the Neighborhood". American Economic Journal: Economic Policy, 3, 169-188.

[60] Shertzer, A. and R. Walsh (2016). "Racial Sorting and the Emergence of Segregation in American Cities". NBER Working Paper 22077.

[61] Tabellini, M. (2018). "Gifts of the Immigrants, Woes of the Natives: Lessons from the Age of Mass Migration". Working Paper.

[62] Tolnay, S. and E. M. Beck (1990). "Black Flight: Lethal Violence and the Great Migration,1900 to 1930". Social Science History, 14(3), 347-370.

[63] Wilkerson, I. (2010). The Warmth of Other Suns: The Epic Story of America's Great Migration. Random House LLC, 2010.

[64] Wright, G. (1986). Old South, New South: Revolutions in the Southern Economy since the Civil War. New York: Basic Books. 


\section{Table 1. Central Cities-Suburbs Inequality (2010)}

\begin{tabular}{lccc}
\hline & Central Cities & Suburbs & Central City to Suburban Outcome \\
\hline Non-Hispanic Whites & $56.9 \%$ & $77.2 \%$ & 0.74 \\
Blacks & $26.7 \%$ & $11.6 \%$ & 2.04 \\
Hispanics & $24.8 \%$ & $16.3 \%$ & 1.52 \\
Poverty rate, families & $22.1 \%$ & $10.6 \%$ & 2.08 \\
Unemployed men (age 25-65) & $10.8 \%$ & $8.6 \%$ & 1.26 \\
High school graduates (men, age 25-65) & $83.4 \%$ & $90 \%$ & 0.92 \\
Median wage (employed men, age 25-65) & $\$ 33,300$ & $\$ 40,000$ & 0.83 \\
\hline
\end{tabular}

Note: Author's calculation from Census Bureau (2010).

\section{Table 2. Summary Statistics}

\begin{tabular}{|c|c|c|c|c|c|c|}
\hline VARIABLES & Mean & Median & St. Dev. & Min & $\operatorname{Max}$ & Obs. \\
\hline City population & 537,344 & 237,395 & 974,513 & 39,578 & $6,930,446$ & 126 \\
\hline White population & 506,340 & 229,755 & 931,592 & 38,465 & $6,587,225$ & 126 \\
\hline Black population & 27,537 & 5,568 & 50,851 & 410 & 327,706 & 126 \\
\hline Predicted black population & 9,670 & 2,350 & 19,613 & 0 & 141,200 & 126 \\
\hline Total tax revenues PC & 19.81 & 16.51 & 9.582 & 7.091 & 53.98 & 126 \\
\hline Property tax revenues PC & 18.49 & 15.73 & 8.560 & 6.215 & 44.70 & 126 \\
\hline $\begin{array}{l}\text { Tax rate per } 1,000 \$ \text { of } \\
\text { assessed valuation }\end{array}$ & 29.74 & 25.03 & 16.78 & 10.39 & 100.7 & 126 \\
\hline Property values PC & 1,255 & 1,117 & 644.4 & 189.2 & 3,769 & 126 \\
\hline Expenditures PC & 17.88 & 15.35 & 7.929 & 6.640 & 43.64 & 126 \\
\hline Educ. spending PC & 6.199 & 4.830 & 2.947 & 1.900 & 14.76 & 126 \\
\hline Police spending PC & 1.841 & 1.596 & 0.925 & 0.492 & 4.693 & 126 \\
\hline Total gross debt PC & 73.43 & 64.22 & 46.56 & 0.125 & 257.4 & 126 \\
\hline
\end{tabular}

Note: The sample includes, for Census years 1910, 1920, and 1930, the 42 largest central cities that were anchored to a MSA and had at least 100,000 residents in 1930, and for which it was possible to construct the instrument for black migration, as discussed in the main text. Predicted blacks in the fourth row of the Table refers to predicted black immigration, i.e. the instrument for black population constructed in Section 5.2. All spending and revenues data are expressed in 1910 dollars. Nominal values for 1920 and 1930 are deflated using the CPI from the Minneapolis FED. 
Table 3. First Stage

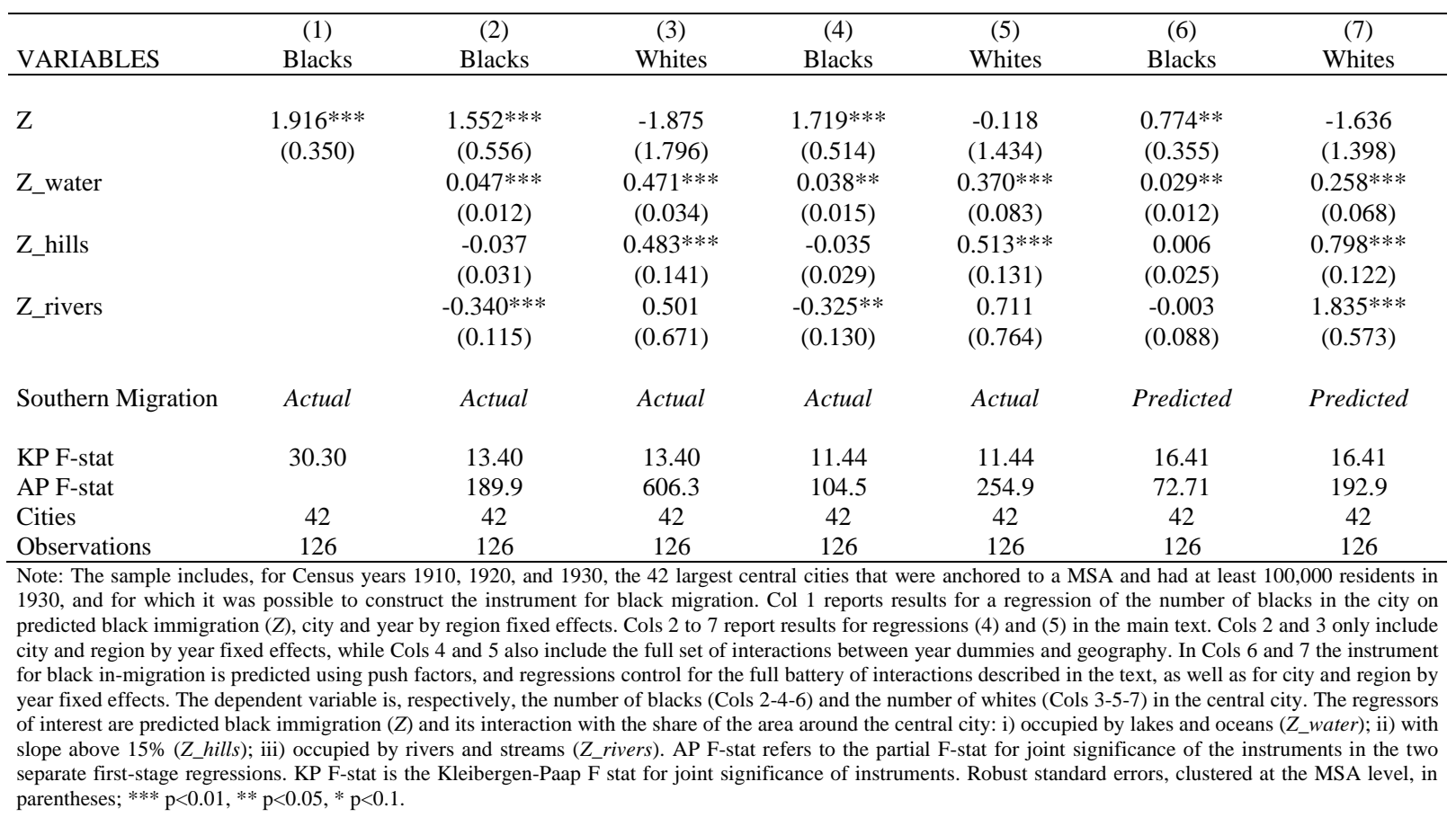

\section{Table 4. Tax Revenues, Tax Rate, and Property Values}

\begin{tabular}{|c|c|c|c|c|c|c|c|}
\hline VARIABLES & $\begin{array}{c}1) \\
\text { Tot. tax } \\
\text { revenues PC } \\
\end{array}$ & $\begin{array}{c}(2) \\
\text { Prop. tax } \\
\text { revenues PC } \\
\end{array}$ & $\begin{array}{c}3) \\
\text { Prop. tax } \\
\text { revenues PC } \\
\end{array}$ & $\begin{array}{c}\text { (4) } \\
\text { Prop. tax rate }\end{array}$ & $\begin{array}{c}(5) \\
\text { Prop. values over } \\
1900 \text { population } \\
\end{array}$ & $\begin{array}{c}(6) \\
\text { Prop. values over } \\
1910 \text { population } \\
\end{array}$ & $\begin{array}{c}\text { (7) } \\
\text { Prop. values } \\
\text { PC } \\
\end{array}$ \\
\hline \multicolumn{8}{|l|}{ Panel A: OLS } \\
\hline $\begin{array}{l}\text { Blacks } \\
\text { Whites }\end{array}$ & $\begin{array}{c}-0.085^{* *} \\
(0.041) \\
0.011^{*} \\
(0.006)\end{array}$ & $\begin{array}{c}-0.067 * \\
(0.035) \\
0.008 \\
(0.005)\end{array}$ & $\begin{array}{c}-0.081 * * \\
(0.041) \\
0.009 \\
(0.006)\end{array}$ & $\begin{array}{c}0.023 \\
(0.064) \\
-0.006 \\
(0.009)\end{array}$ & $\begin{array}{l}-14.51 \\
(12.23) \\
2.523 \\
(2.263)\end{array}$ & $\begin{array}{c}-4.543 \\
(4.822) \\
0.785 \\
(0.885)\end{array}$ & $\begin{array}{c}-1.216 \\
(3.643) \\
0.286 \\
(0.506)\end{array}$ \\
\hline \multicolumn{8}{|l|}{ Panel B: 2SLS } \\
\hline $\begin{array}{l}\text { Blacks } \\
\text { Whites }\end{array}$ & $\begin{array}{c}-0.101 * * * \\
(0.033) \\
0.012 * * * \\
(0.004)\end{array}$ & $\begin{array}{c}-0.093 * * * \\
(0.029) \\
0.010 * * * \\
(0.004)\end{array}$ & $\begin{array}{c}-0.110 * * * \\
(0.035) \\
0.011 * * \\
(0.005)\end{array}$ & $\begin{array}{c}0.098 \\
(0.067) \\
-0.016 \\
(0.010)\end{array}$ & $\begin{array}{c}-18.12 * * \\
(8.738) \\
1.990 \\
(1.246)\end{array}$ & $\begin{array}{c}-9.059 * * \\
(4.190) \\
0.969 \\
(0.616)\end{array}$ & $\begin{array}{c}-5.796^{*} \\
(3.374) \\
0.766 \\
(0.503)\end{array}$ \\
\hline $\begin{array}{l}\text { KP F-stat } \\
\text { AP (Blacks) } \\
\text { AP (Whites) }\end{array}$ & $\begin{array}{l}13.40 \\
189.9 \\
606.3\end{array}$ & $\begin{array}{l}13.40 \\
189.9 \\
606.3\end{array}$ & $\begin{array}{l}11.44 \\
104.5 \\
254.9\end{array}$ & $\begin{array}{l}11.44 \\
104.5 \\
254.9\end{array}$ & $\begin{array}{l}11.44 \\
104.5 \\
254.9\end{array}$ & $\begin{array}{l}11.44 \\
104.5 \\
254.9\end{array}$ & $\begin{array}{l}11.44 \\
104.5 \\
254.9\end{array}$ \\
\hline $\begin{array}{l}\text { Mean dep var } \\
\text { Observations }\end{array}$ & $\begin{array}{c}15.63 \\
126\end{array}$ & $\begin{array}{c}15.16 \\
126\end{array}$ & $\begin{array}{c}15.16 \\
126\end{array}$ & $\begin{array}{c}23.12 \\
126\end{array}$ & $\begin{array}{c}1,308 \\
126\end{array}$ & $\begin{array}{c}860.1 \\
126\end{array}$ & $\begin{array}{c}860.1 \\
126\end{array}$ \\
\hline
\end{tabular}

Note: The sample includes, for Census years 1910, 1920, and 1930, the 42 largest central cities that were anchored to a MSA and had at least 100,000 residents in 1930, and for which it was possible to construct the instrument for black migration. Panels A and B report, respectively OLS and 2SLS results. The dependent variable is displayed at the top of each column, and refers to real 1910 dollars. The regressors of interest are the number of blacks (Blacks) and whites (Whites) in the central city, and are instrumented with, respectively, predicted black immigration and its interaction with the area around the city that: i) had slope above $15 \%$; ii) is occupied by lakes and oceans; iii) is occupied by rivers and stream (see Sections 5.2 and 5.3 in the main text). AP (blacks) and AP (whites) refer to the partial F-stats for joint significance of the instruments in the two separate first-stage regressions. KP F-stat is the Kleibergen-Paap F stat for joint significance of instruments. First stage results are reported in Table 3. All columns also report the mean of the dependent variable at baseline. All regressions control for city and year by region fixed effects. Cols 3 to 7 also include interactions between year dummies and dummies for: i) 1900 fraction of blacks; ii) latitude and longitude; and iii) the presence of geographic features around the central city. Robust standard errors, clustered at the MSA level, in parentheses; $* * * \mathrm{p}<0.01, * * \mathrm{p}<0.05, * \mathrm{p}<0.1$ 
Table 5. Public Spending Per Capita

\begin{tabular}{|c|c|c|c|c|c|c|c|c|}
\hline VARIABLES & $\begin{array}{c}(1) \\
\text { Total }\end{array}$ & $\begin{array}{c}\text { (2) } \\
\text { Education }\end{array}$ & $\begin{array}{c}\text { (3) } \\
\text { Police }\end{array}$ & $\begin{array}{l}(4) \\
\text { Fire }\end{array}$ & $\begin{array}{c}5) \\
\text { Sewerage } \\
\text { and garbage }\end{array}$ & $\begin{array}{c}(6) \\
\text { Road }\end{array}$ & $\begin{array}{c}(7) \\
\text { Charities and } \\
\text { hospitals }\end{array}$ & $\begin{array}{c}(8) \\
\text { Outdoor } \\
\text { poverty relief }\end{array}$ \\
\hline \multicolumn{9}{|l|}{ Panel A: OLS } \\
\hline Blacks & $\begin{array}{c}-0.053^{*} \\
(0.028)\end{array}$ & $\begin{array}{c}-0.028 * * \\
(0.011)\end{array}$ & $\begin{array}{c}-0.001 \\
(0.004)\end{array}$ & $\begin{array}{c}-0.002 \\
(0.002)\end{array}$ & $\begin{array}{l}-0.004 \\
(0.003)\end{array}$ & $\begin{array}{l}-0.003 \\
(0.006)\end{array}$ & $\begin{array}{c}-0.011 * * \\
(0.005)\end{array}$ & $\begin{array}{c}-0.013 * * * \\
(0.004)\end{array}$ \\
\hline Whites & $\begin{array}{c}0.007 \\
(0.006)\end{array}$ & $\begin{array}{l}0.003^{*} \\
(0.002)\end{array}$ & $\begin{array}{c}0.001 \\
(0.001)\end{array}$ & $\begin{array}{c}0.000 \\
(0.000)\end{array}$ & $\begin{array}{c}0.001 * * \\
(0.000)\end{array}$ & $\begin{array}{l}-0.000 \\
(0.001)\end{array}$ & $\begin{array}{c}0.001 \\
(0.001)\end{array}$ & $\begin{array}{c}0.002^{* *} \\
(0.001)\end{array}$ \\
\hline \multicolumn{9}{|l|}{ Panel B: $2 S L S$} \\
\hline Blacks & $\begin{array}{c}-0.041^{*} \\
(0.024)\end{array}$ & $\begin{array}{c}-0.041 * * * \\
(0.012)\end{array}$ & $\begin{array}{c}-0.007 * * \\
(0.003)\end{array}$ & $\begin{array}{l}-0.005 \\
(0.003)\end{array}$ & $\begin{array}{c}-0.008 * * * \\
(0.003)\end{array}$ & $\begin{array}{l}-0.006 \\
(0.007)\end{array}$ & $\begin{array}{c}0.001 \\
(0.007)\end{array}$ & $\begin{array}{l}-0.010 * \\
(0.006)\end{array}$ \\
\hline Whites & $\begin{array}{c}0.003 \\
(0.004)\end{array}$ & $\begin{array}{c}0.005^{* * *} * \\
(0.002)\end{array}$ & $\begin{array}{c}0.001 * * * \\
(0.000)\end{array}$ & $\begin{array}{c}0.000 \\
(0.000)\end{array}$ & $\begin{array}{c}0.002 * * * \\
(0.000)\end{array}$ & $\begin{array}{l}-0.000 \\
(0.001)\end{array}$ & $\begin{array}{l}-0.001 \\
(0.001)\end{array}$ & $\begin{array}{c}0.001 \\
(0.001)\end{array}$ \\
\hline KP F-stat & 11.44 & 11.44 & 11.44 & 11.44 & 11.44 & 11.44 & 11.99 & 9.327 \\
\hline AP (Blacks) & 104.5 & 104.5 & 104.5 & 104.5 & 104.5 & 104.5 & 95.50 & 7.62 \\
\hline AP (Whites) & 254.9 & 254.9 & 254.9 & 254.9 & 254.9 & 254.9 & 239.3 & 41.58 \\
\hline Mean dep var & 15.21 & 4.656 & 1.812 & 1.801 & 1.802 & 1.043 & 1.892 & 0.144 \\
\hline Observations & 126 & 126 & 126 & 126 & 126 & 126 & 122 & 42 \\
\hline \multicolumn{9}{|c|}{ 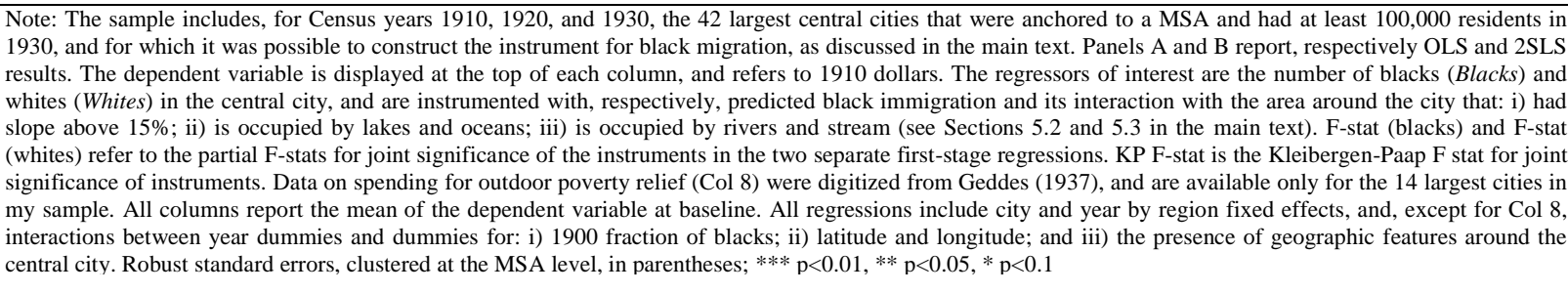 } \\
\hline
\end{tabular}




\section{Table 6. Spending Shares}

\begin{tabular}{|c|c|c|c|c|c|c|}
\hline VARIABLES & $\begin{array}{c}(1) \\
\text { Education }\end{array}$ & $\begin{array}{c}(2) \\
\text { Police }\end{array}$ & $\begin{array}{l}(3) \\
\text { Fire }\end{array}$ & $\begin{array}{c}(4) \\
\text { Sewerage and } \\
\text { garbage }\end{array}$ & $\begin{array}{l}(5) \\
\text { Road }\end{array}$ & $\begin{array}{c}(6) \\
\text { Charities and } \\
\text { hospitals }\end{array}$ \\
\hline \multicolumn{7}{|l|}{ Panel A: $O L S$} \\
\hline $\begin{array}{l}\text { Blacks } \\
\text { Whites }\end{array}$ & $\begin{array}{c}0.001 \\
(0.019) \\
-0.002 \\
(0.003)\end{array}$ & $\begin{array}{c}-0.003 \\
(0.010) \\
0.002 \\
(0.001)\end{array}$ & $\begin{array}{c}0.029 * * * \\
(0.008) \\
-0.002 * \\
(0.001)\end{array}$ & $\begin{array}{c}-0.002 \\
(0.010) \\
0.002 \\
(0.001)\end{array}$ & $\begin{array}{c}0.015 \\
(0.019) \\
-0.004 \\
(0.002)\end{array}$ & $\begin{array}{c}-0.035^{* * * *} \\
(0.010) \\
0.004 \\
(0.003)\end{array}$ \\
\hline \multicolumn{7}{|l|}{ Panel B: 2SLS } \\
\hline $\begin{array}{l}\text { Blacks } \\
\text { Whites }\end{array}$ & $\begin{array}{l}-0.078^{*} \\
(0.044) \\
0.011^{*} \\
(0.007)\end{array}$ & $\begin{array}{l}-0.029^{*} \\
(0.017) \\
0.005^{*} \\
(0.003)\end{array}$ & $\begin{array}{c}0.031 * * * \\
(0.011) \\
-0.003 \\
(0.002)\end{array}$ & $\begin{array}{c}-0.031 * \\
(0.016) \\
0.007 * * * \\
(0.002)\end{array}$ & $\begin{array}{c}0.012 \\
(0.032) \\
-0.003 \\
(0.004)\end{array}$ & $\begin{array}{l}-0.010 \\
(0.015) \\
-0.002 \\
(0.002)\end{array}$ \\
\hline $\begin{array}{l}\text { KP F-stat } \\
\text { AP (Blacks) } \\
\text { AP (Whites) }\end{array}$ & $\begin{array}{l}11.44 \\
104.5 \\
254.9\end{array}$ & $\begin{array}{l}11.44 \\
104.5 \\
254.9\end{array}$ & $\begin{array}{l}11.44 \\
104.5 \\
254.9\end{array}$ & $\begin{array}{l}11.44 \\
104.5 \\
254.9\end{array}$ & $\begin{array}{l}11.44 \\
104.5 \\
254.9\end{array}$ & $\begin{array}{l}11.99 \\
95.50 \\
239.3\end{array}$ \\
\hline $\begin{array}{l}\text { Mean dep var } \\
\text { Observations }\end{array}$ & $\begin{array}{c}31.87 \\
126\end{array}$ & $\begin{array}{c}11.77 \\
126\end{array}$ & $\begin{array}{c}12.31 \\
126\end{array}$ & $\begin{array}{c}6.919 \\
126\end{array}$ & $\begin{array}{c}12.29 \\
126\end{array}$ & $\begin{array}{c}4.796 \\
122\end{array}$ \\
\hline $\begin{array}{l}\text { Note: The sample } \\
\text { 1930, and for wh } \\
\text { variable, displayee } \\
\text { blacks (Blacks) an } \\
\text { the city that: i) ha } \\
\text { (whites) refer to th } \\
\text { significance of ins } \\
\text { interactions betwe }\end{array}$ & $\begin{array}{l}\text { for Census } \\
\text { s possible to } \\
\text { p of each col } \\
\text { (Whites) in tl } \\
\text { bove } 15 \% \text {; ii) } \\
\text { F-stats for jo } \\
\text { All columns } \\
\text { lummies and } \\
\text { d errors, clust }\end{array}$ & $\begin{array}{l}\text { 1920, a } \\
\text { the instru } \\
\text { e share of } \\
\text { city, and } \\
\text { ied by lak } \\
\text { cance of tl } \\
\text { rt the me: } \\
\text { for: i) } 19\end{array}$ & $\begin{array}{l}\text { e } 42 \text { larges } \\
\text { lack migra } \\
\text { n a given ca } \\
\text { ented with, } \\
\text { ans; iii) is o } \\
\text { nts in the tv } \\
\text { pendent val } \\
\text { of blacks; } \\
\text { theses; } * * *\end{array}$ & $\begin{array}{l}\text { cities that were an } \\
\text { els A and B repo } \\
\text { er total current ex } \\
\text { ely, predicted bla } \\
\text { y rivers and strea } \\
\text { te first-stage regre } \\
\text { aseline. All regre } \\
\text { le and longitude; } \\
* * \text { p }<0.05, * p<0 \text {. }\end{array}$ & $\begin{array}{l}\text { MSA and } \\
\text { ely OLS } \\
\text { The regre } \\
\text { tion and it } \\
\text { tions } 5.2 \text { a } \\
\text { F-stat is th } \\
\text { de city an } \\
\text { presence }\end{array}$ & $\begin{array}{l}100,000 \text { residents } \\
\text { sults. The depend } \\
\text { est are the number } \\
\text { with the area arou } \\
\text { at (blacks) and F-s } \\
\text { n-Paap F stat for jo } \\
\text { gion fixed effects a } \\
\text { c features around }\end{array}$ \\
\hline
\end{tabular}




\section{Table 7. Public Debt Per Capita}

\begin{tabular}{|c|c|c|c|c|}
\hline VARIABLES & $\begin{array}{c}(1) \\
\text { Total gross debt } \\
\end{array}$ & $\begin{array}{c}(2) \\
\text { Current gross debt } \\
\end{array}$ & $\begin{array}{c}(3) \\
\text { Net debt }\end{array}$ & $\begin{array}{c}\text { (4) } \\
\text { Debt to tax revenues ratio }\end{array}$ \\
\hline \multicolumn{5}{|l|}{ Panel A: OLS } \\
\hline Blacks & $\begin{array}{l}0.474 * * * \\
(0.167)\end{array}$ & $\begin{array}{c}0.125 \\
(0.122)\end{array}$ & $\begin{array}{c}0.203 \\
(0.150)\end{array}$ & $\begin{array}{c}0.026 * * \\
(0.011)\end{array}$ \\
\hline Whites & $\begin{array}{l}-0.031 \\
(0.039)\end{array}$ & $\begin{array}{l}-0.008 \\
(0.017)\end{array}$ & $\begin{array}{l}-0.026 \\
(0.034)\end{array}$ & $\begin{array}{l}-0.002 \\
(0.002)\end{array}$ \\
\hline \multicolumn{5}{|l|}{ Panel B: $2 S L S$} \\
\hline Blacks & $\begin{array}{l}0.572 * * * \\
(0.182)\end{array}$ & $\begin{array}{l}0.238 \\
(0.174)\end{array}$ & $\begin{array}{c}0.362^{* *} \\
(0.149)\end{array}$ & $\begin{array}{l}0.050 * * * \\
(0.013)\end{array}$ \\
\hline Whites & $\begin{array}{l}-0.076 * * * \\
(0.025)\end{array}$ & $\begin{array}{l}-0.027 \\
(0.023)\end{array}$ & $\begin{array}{c}-0.079 * * * \\
(0.019)\end{array}$ & $\begin{array}{c}-0.007 * * * \\
(0.002)\end{array}$ \\
\hline KP F-stat & 11.44 & 11.44 & 11.44 & 11.44 \\
\hline AP (Blacks) & 104.5 & 104.5 & 104.5 & 104.5 \\
\hline AP (Whites) & 254.9 & 254.9 & 254.9 & 254.9 \\
\hline Mean dep var & 67.09 & 10.58 & 47.11 & 4.222 \\
\hline Observations & 126 & 126 & 126 & 126 \\
\hline \multicolumn{5}{|c|}{$\begin{array}{l}\text { Note: The sample includes, for Census years } 1910,1920 \text {, and 1930, the } 42 \text { largest central cities that were anchored to a MSA and had at least } 100,000 \text { residents in } \\
1930 \text {, and for which it was possible to construct the instrument for black migration. Panels A and B report, respectively OLS and } 2 \text { SLS results. The dependent } \\
\text { variable, expressed in } 1910 \text { dollars, is displayed at the top of each column. All outcomes refer to per capita values. In Col } 4 \text {, the dependent variable is the ratio of } \\
\text { total debt to total tax revenues. The regressors of interest are the number of blacks (Blacks) and whites (Whites) in the central city, and are instrumented with, } \\
\text { respectively, predicted black immigration and its interaction with the area around the city that: i) had slope above } 15 \% \text {; ii) is occupied by lakes and oceans; iii) is } \\
\text { occupied by rivers and stream (see Sections } 5.2 \text { and } 5.3 \text { ). AP (blacks) and AP (whites) refer to the partial F-stats for joint significance of the instruments in the two } \\
\text { separate first-stage regressions. KP F-stat is the Kleibergen-Paap F stat for joint significance of instruments. All columns also report the mean of the dependent } \\
\text { variable at baseline. All regressions include city and year by region fixed effects and interactions between year dummies and dummies for: i) } 1900 \text { fraction of blacks; } \\
\text { ii) latitude and longitude; and iii) the presence of geographic features around the central city. Robust standard errors, clustered at the MSA level, in parentheses; *** } \\
\text { p }<0.01, * * p<0.05, * p<0.1\end{array}$} \\
\hline
\end{tabular}




\section{Table 8. Replicating Results Omitting White Population}

\begin{tabular}{|c|c|c|c|c|c|c|}
\hline VARIABLES & $\begin{array}{c}\text { (1) } \\
\text { Total tax } \\
\text { revenues PC }\end{array}$ & $\begin{array}{c}(2) \\
\text { Property tax } \\
\text { revenues PC }\end{array}$ & $\begin{array}{c}\text { (3) } \\
\text { Property tax } \\
\text { rate } \\
\end{array}$ & $\begin{array}{c}(4) \\
\text { Property values } \\
\text { over } 1900 \text { pop }\end{array}$ & $\begin{array}{c}(5) \\
\text { Total spending PC }\end{array}$ & $\begin{array}{c}\text { (6) } \\
\text { Spending on } \\
\text { education PC }\end{array}$ \\
\hline \multicolumn{7}{|c|}{ Panel A: Baseline IV } \\
\hline Blacks & $\begin{array}{c}-0.154 * * \\
(0.076)\end{array}$ & $\begin{array}{c}-0.169 * * \\
(0.068)\end{array}$ & $\begin{array}{c}0.030 \\
(0.094)\end{array}$ & $\begin{array}{c}-60.36^{* * * *} \\
(18.57)\end{array}$ & $\begin{array}{l}-0.131 * * \\
(0.064)\end{array}$ & $\begin{array}{c}-0.059 * * * \\
(0.020)\end{array}$ \\
\hline KP F-stat & 9.347 & 9.347 & 9.347 & 9.347 & 9.347 & 9.347 \\
\hline \multicolumn{7}{|c|}{ Panel B: Push Factors IV } \\
\hline Blacks & $\begin{array}{c}-0.261 * * * \\
(0.061)\end{array}$ & $\begin{array}{c}-0.269 * * * \\
(0.069)\end{array}$ & $\begin{array}{c}0.037 \\
(0.098)\end{array}$ & $\begin{array}{c}-71.14 * * * \\
(25.32)\end{array}$ & $\begin{array}{c}-0.177 * * \\
(0.077)\end{array}$ & $\begin{array}{c}-0.084 * * * \\
(0.029)\end{array}$ \\
\hline KP F-stat & 6.325 & 6.325 & 6.325 & 6.325 & 6.325 & 6.325 \\
\hline Mean dep var & 15.63 & 15.16 & 23.12 & 1,308 & 15.21 & 4.656 \\
\hline Observations & 126 & 126 & 126 & 126 & 126 & 126 \\
\hline
\end{tabular}




\section{Table 9. High vs Low Population Growth Cities}

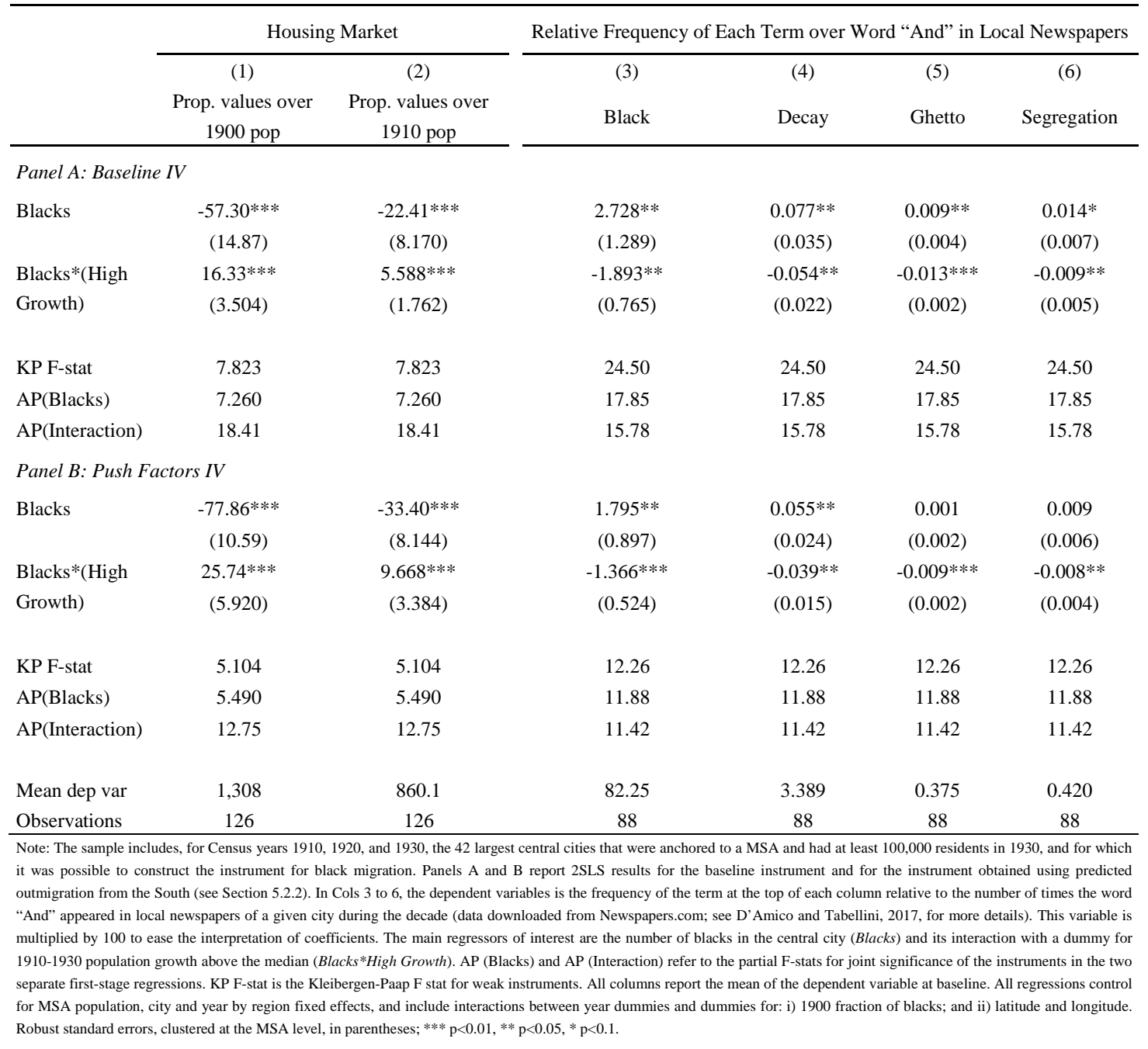




\section{Figure 1. Number of Black Migrants, by Decade}

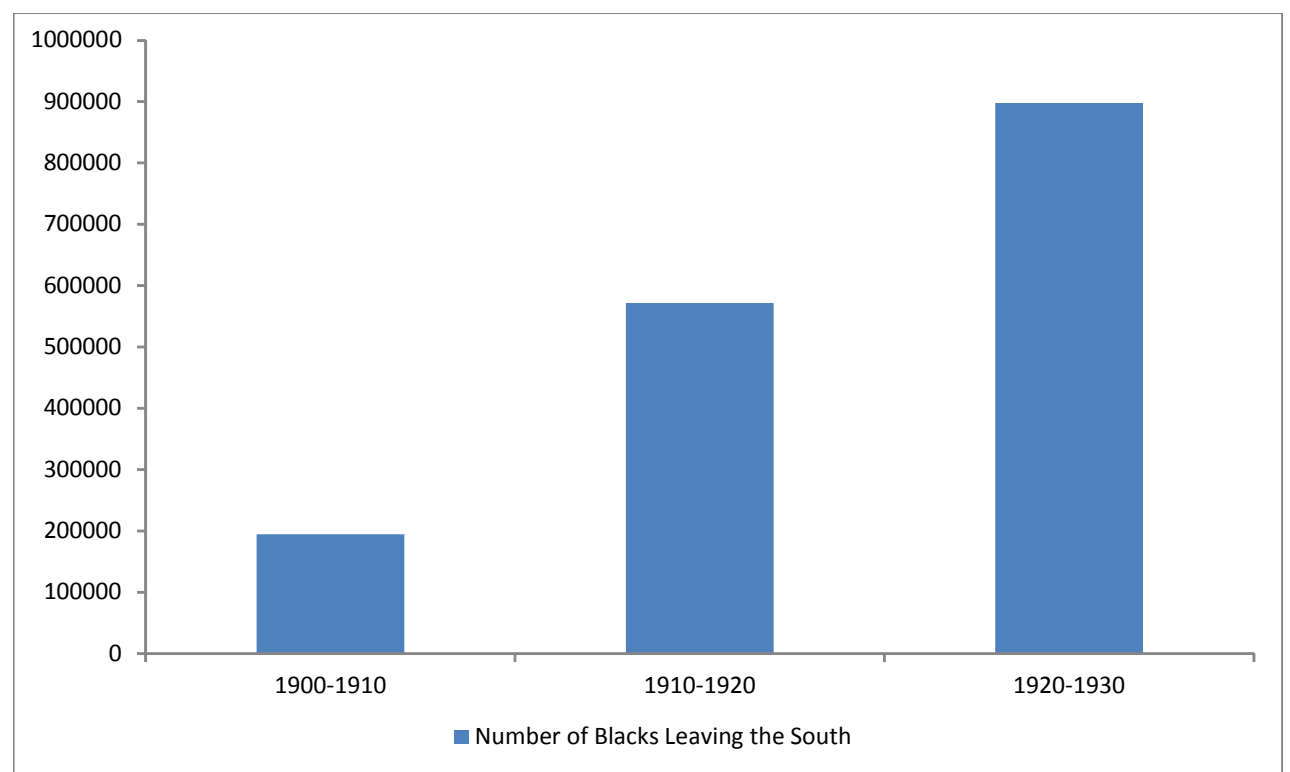

Note: Author's calculations using Census of Population data from IPUMS 1\% samples for years 1900 to 1930 . The number of net migrants from US Southern states is estimated using the forward survival method as in Gregory (2005). First, mortality rates are estimated by age-sex-race groups using national data from US Census of Population (1900-1930). Then, net migration for each Southern state is computed by adjusting changes in population (for each age-sex-race group) for estimated mortality rates. Finally, net migration for each southern state is aggregated for the South as a whole.

Figure 2. Fraction of African Americans Living in the North, by Decade

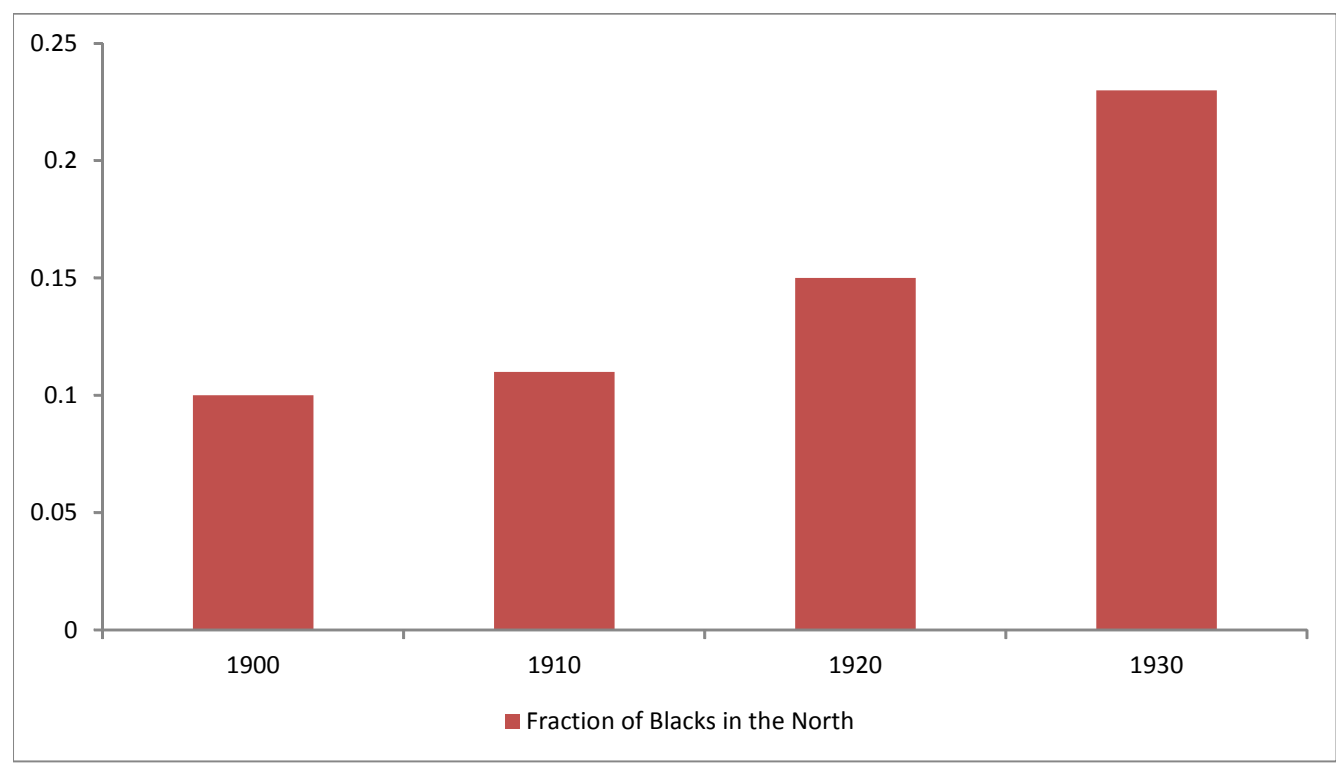

Note: The Figure plots the fraction of African Americans living in the North of the United States by decade. Author's calculations from US Census of Population (1900-1930). 


\section{Figure 3. The First Wave of the Great Migration}
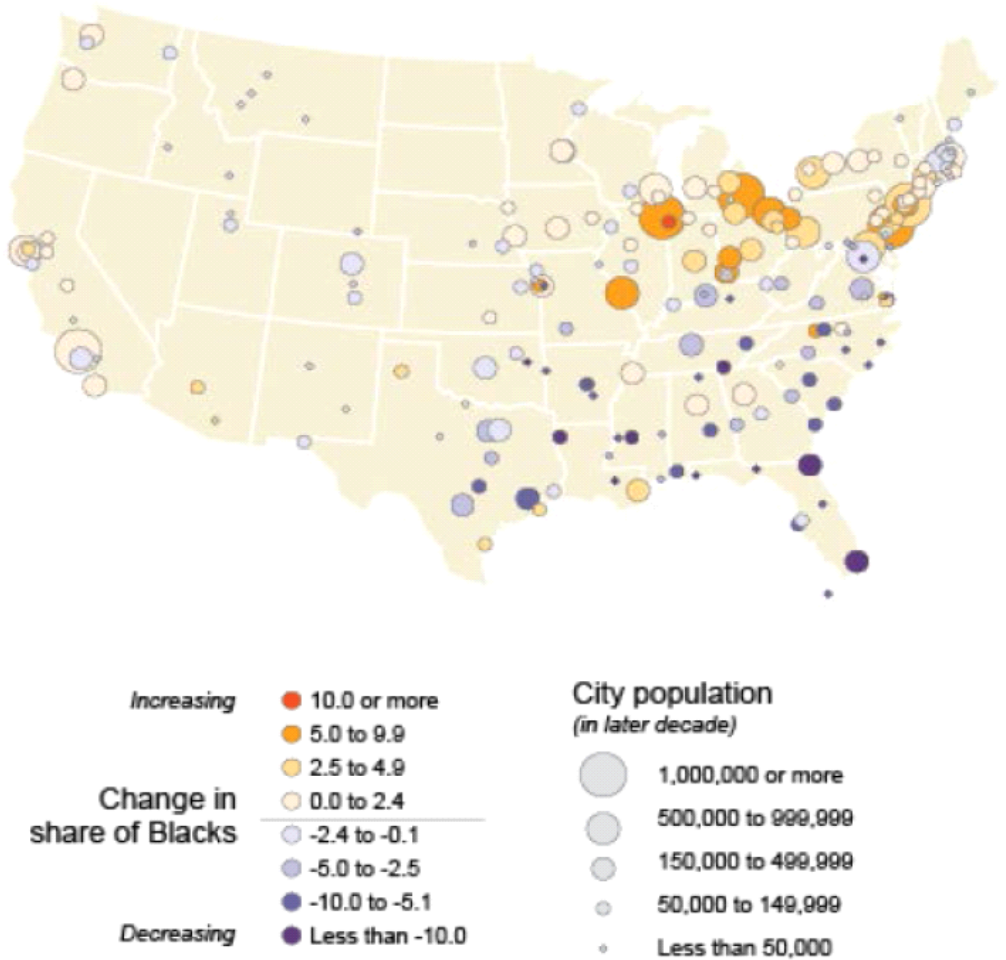

Note: The change of the share of Blacks in cities is based on the percentage point difference in the percent of the population that was black in 1940, relative to 1910. The Figure comes from the US Census Bureau.

Figure 4. Share of Blacks from Southern States in Northern Cities, 1900

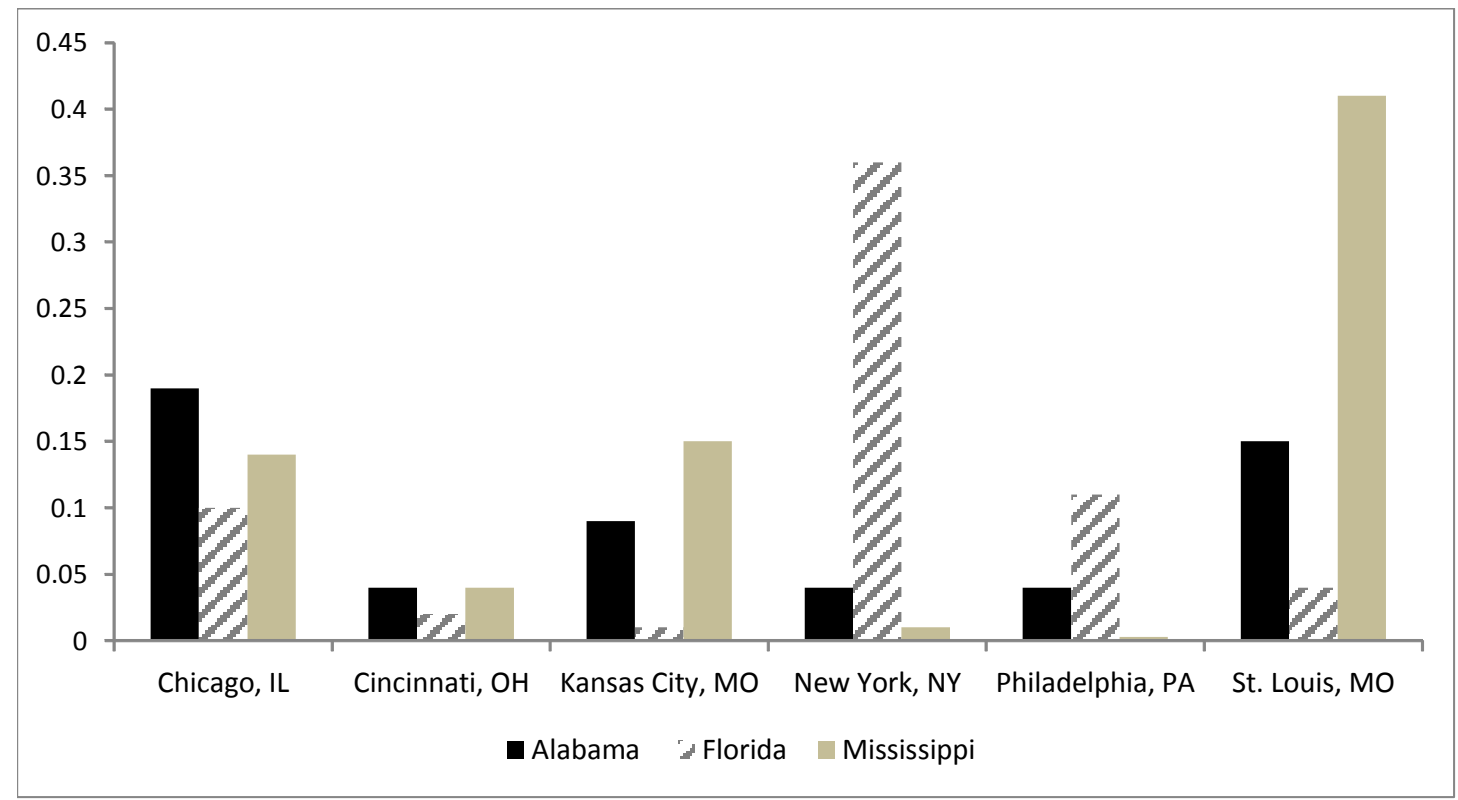

Note: The Figure shows the fraction of southern born blacks from a given state residing in the North living in one of the selected northern cities in 1900. Author's calculation from the 1900 US Census of Population (Ruggles et al., 2015). 


\section{Figure 5. First Stage: Actual vs Predicted Black Population}

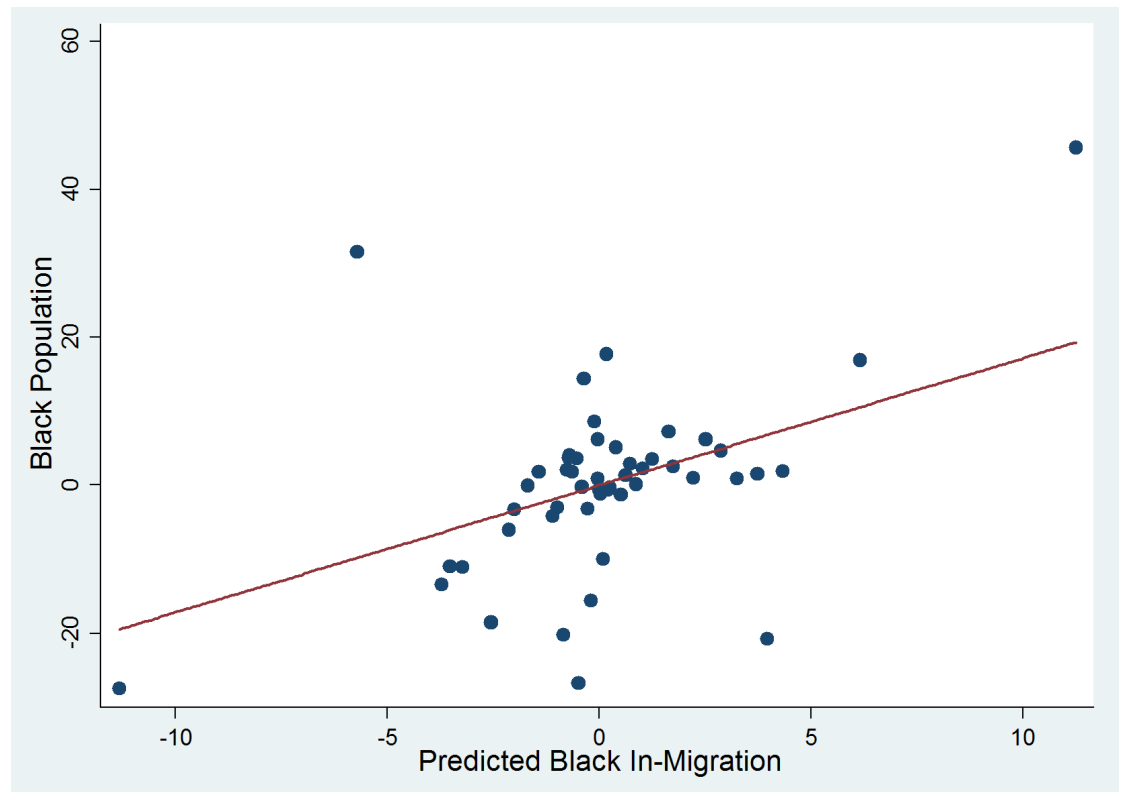

Note: The y-axis reports the actual number of blacks in northern cities in each decade between 1910 and 1930, and the xaxis shows the predicted number of black migrants, constructed as described in the text (Section 5.2). Each point in the binscatter diagram represents the residual change in a city's actual and predicted number of blacks after partialling out: the interaction between predicted black immigration and the geographic variables listed in the main text (Section 5.3); city and year by region fixed effects; interactions between year dummies geography (see Section 5.3).

\section{Figure 6. Predicted Black Inflows, Property Values, and Tax Rates}
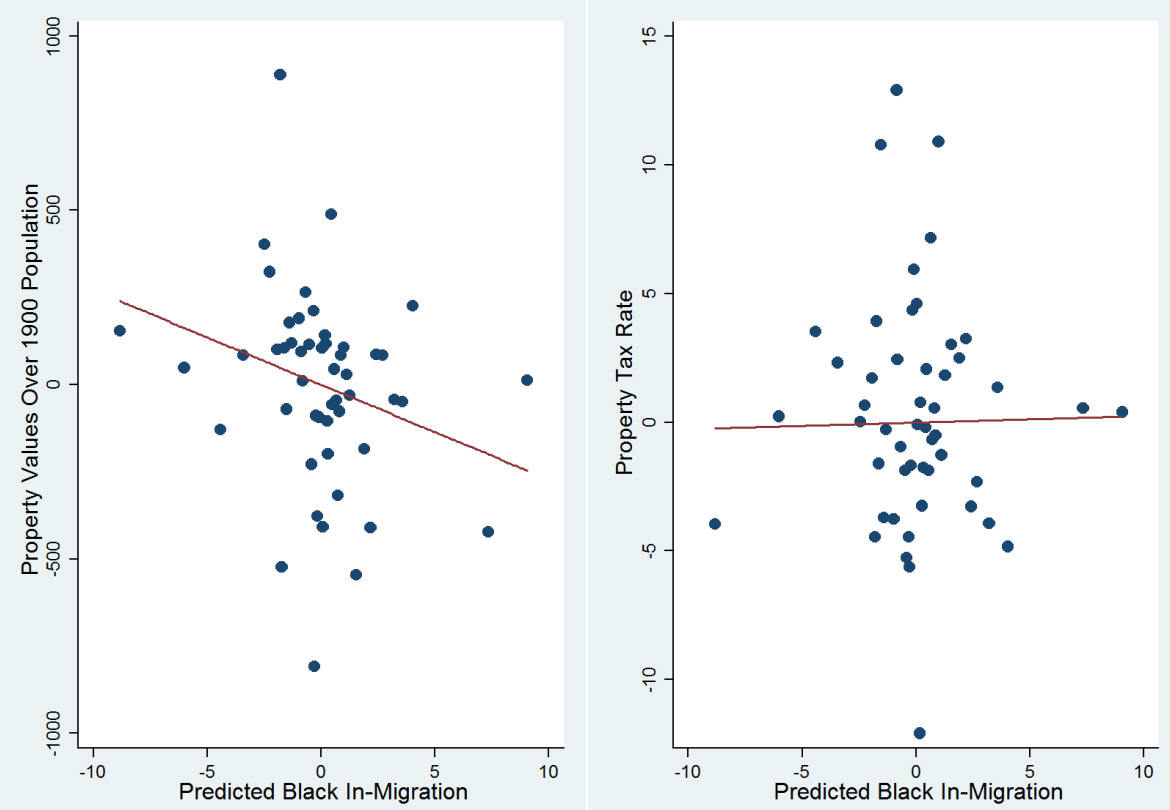

Note: The x-axis reports the predicted number of blacks in northern cities in each decade between 1910 and 1930, and the yaxis shows, respectively, property values over 1900 population (left panel) and the property tax rate (right panel). Each point in the bin-scatter diagram represents the residual change of these variables after partialling out: the interaction between predicted black migration and the geographic variables listed in the main text (Section 5.3); city and year by region fixed effects; interactions between year dummies and: geography (see Section 5.3); the fraction of blacks in 1900; latitude and longitude. 


\section{Appendix. Supplementary Tables and Figures}

Table A1. List of Southern States

\begin{tabular}{ll}
\hline Alabama & North Carolina \\
Arkansas & Oklahoma \\
Florida & South Carolina \\
Georgia & Tennessee \\
Kentucky & Texas \\
Louisiana & Virginia \\
Mississippi & West Virginia \\
\hline Note: The table reports the southern states used to construct the instrument for black population. As in Boustan (2010), I \\
exclude Maryland, since Baltimore received large inflows of blacks during this period. For the same reason, I do not include \\
the state of Delaware, since the city of Wilmington - its main central city - received a net inflow of African Americans \\
during the first wave of the Great Migration.
\end{tabular}

\section{Table A2. List of Cities}

\begin{tabular}{lll}
\hline Albany, NY & Evansville, IN & Providence, RI \\
Baltimore, MD & Hartford, CT & Rochester, NY \\
Boston, MA & Indianapolis, IN & St. Louis, MO \\
Bridgeport, CT & Kansas City, MO & Salt Lake City, UT \\
Buffalo, NY & Los Angeles, CA & San Diego, CA \\
Chicago, IL & Milwaukee, WI & San Francisco, CA \\
Cincinnati, OH & Minneapolis, MN & Scranton, PA \\
Cleveland, OH & New Haven, CT & Seattle, WA \\
Columbus, OH & New York, NY & Springfield, MA \\
Dayton, OH & Omaha, NE & Tacoma, WA \\
Denver, CO & Peoria, IL & Trenton, NJ \\
Des Moines, IA & Philadelphia, PA & Washington, DC \\
Detroit, MI & Pittsburgh, PA & Wichita, KS \\
Duluth, MN & Portland, OR & Youngstown, OH \\
\hline Note: The sample includes the 42 largest central cities that were anchored to a MSA and had at least 100,000 residents in \\
1930, and for which it was possible to construct the instrument for black migration, as discussed in the main text.
\end{tabular}




\section{Table A3. Variables' Sources and Definitions}

\begin{tabular}{|c|c|}
\hline Variable & Source \\
\hline City population (total and by race) & US Census of Population \\
\hline Number of families & US Census of Population \\
\hline Number of illiterate (total and by race) & US Census of Population \\
\hline Pupils enrolled in public schools & US Census of Population \\
\hline City population by age & US Census of Population \\
\hline City population by nativity & US Census of Population \\
\hline Net migration from southern states & Estimated using US Census data (ICPSR 2896) \\
\hline Public Spending (total and by category) & Financial Statistics of Cities \\
\hline Assessed valuation of property & Financial Statistics of Cities \\
\hline Tax rate on $\$ 1,000$ of assessed valuation & Financial Statistics of Cities \\
\hline Tax revenues & Financial Statistics of Cities \\
\hline Land area (in km) & Financial Statistics of Cities \\
\hline Spending on poverty relief & Geddes (1937) \\
\hline Selected terms from local newspapers & Newspapers.com \\
\hline Number of highway rays planned and built & Baum-Snow (2007) \\
\hline Number of special districts by county & US Census of Governments \\
\hline Number of municipalities by county & US Census of Governments \\
\hline County-level Presidential and Congressional elections & ICPSR 8611 \\
\hline At large elections (1940) & Municipal Year Book (1940) \\
\hline Elevation data & USGS \\
\hline Rivers and streams & USGS \\
\hline Lakes and oceans & USGS and Saiz (2010) \\
\hline Average January temperature & US climate data \\
\hline
\end{tabular}


Table A4. City Demographic Characteristics, by Decade

\begin{tabular}{|c|c|c|c|c|c|}
\hline & Mean & Median & St. Deviation & Min & Max \\
\hline \multicolumn{6}{|l|}{ Panel A. 1910} \\
\hline Total population & 427,125 & 215,700 & 792,830 & 39,500 & $4,766,800$ \\
\hline White population & 409,853 & 209,425 & 775,263 & 38,465 & $4,669,172$ \\
\hline Black population & 15,335 & 3,245 & 26,340 & 410 & 94,446 \\
\hline Immigrants & 130,152 & 38,345 & 317,876 & 2,931 & $1,954,381$ \\
\hline \multicolumn{6}{|l|}{ Panel B. 1920} \\
\hline Total population & 534,526 & 257,300 & 941,446 & 72,200 & $5,620,000$ \\
\hline White population & 507,556 & 250,952 & 909,512 & 68,623 & $5,459,463$ \\
\hline Black population & 24,861 & 5,583 & 39,768 & 495 & 152,467 \\
\hline Immigrants & 138,972 & 42,067 & 332,963 & 3,107 & $2,049,446$ \\
\hline \multicolumn{6}{|l|}{ Panel C. 1930} \\
\hline Total population & 651,896 & 296,150 & $1,163,806$ & 101,400 & $6,930,400$ \\
\hline White population & 601,612 & 284,577 & $1,094,918$ & 95,714 & $6,587,225$ \\
\hline Black population & 42,415 & 7,779 & 72,262 & 416 & 327,706 \\
\hline Immigrants & 151,924 & 38,048 & 388,399 & 2,134 & $2,408,069$ \\
\hline
\end{tabular}

Table A5. City Finances, by Decade

\begin{tabular}{lccccc}
\hline & Mean & Median & St. Deviation & Min & Max \\
\hline Panel A. 1910 & & & & & \\
Tax Revenues PC & 15.63 & 15.02 & 5.142 & 7.416 & 34.70 \\
Property Taxes PC & 15.15 & 14.55 & 4.727 & 7.232 & 31.30 \\
Tax Rate & 23.12 & 19.97 & 11.92 & 10.70 & 66.23 \\
Spending PC & 15.21 & 14.82 & 4.243 & 8.101 & 27.00 \\
& & & & & \\
Panel B. 1920 & 13.79 & 13.81 & 4.206 & 7.091 & 26.86 \\
Tax Revenues PC & 12.48 & 12.25 & 3.553 & 6.215 & 20.21 \\
Property Taxes PC & 30.41 & 23.89 & 19.15 & 10.39 & 100.7 \\
Tax Rate & 12.01 & 12.24 & 2.963 & 6.640 & 19.82 \\
Spending PC & & & & & \\
& & & & & \\
Panel C. 1930 & 30.01 & 28.81 & 8.615 & 15.94 & 53.98 \\
Tax Revenues PC & 27.81 & 28.30 & 7.148 & 15.07 & 44.70 \\
Property Taxes PC & 35.83 & 31.67 & 16.38 & 13.43 & 86.49 \\
Tax Rate & 26.41 & 25.67 & 6.927 & 14.75 & 43.64 \\
Spending PC &
\end{tabular}

Note: the Table reports summary statistics for the key public finance variables of the 42 cities in my sample, separately for each of the three decades. Source: author's calculations from the Financial Statistics of Cities. 
Table A6. City Finances, by City Size and by Decade

\begin{tabular}{|c|c|c|c|c|}
\hline & Bottom $25^{\text {th }}$ pctile & $25^{\text {th }}-50^{\text {th }}$ pctile & $50^{\text {th }}-75^{\text {th }}$ pctile & Top $75^{\text {th }}$ pctile \\
\hline \multicolumn{5}{|l|}{ Panel A. 1910} \\
\hline Tax Revenues PC & 12.96 & 13.71 & 16.29 & 19.76 \\
\hline Property Taxes PC & 12.63 & 13.20 & 15.99 & 18.96 \\
\hline Tax Rate & 25.48 & 23.84 & 20.65 & 22.53 \\
\hline Spending PC & 12.52 & 12.98 & 16.89 & 18.57 \\
\hline \multicolumn{5}{|l|}{ Panel B. 1920} \\
\hline Tax Revenues PC & 11.86 & 11.47 & 15.38 & 16.52 \\
\hline Property Taxes PC & 10.89 & 10.39 & 14.00 & 14.67 \\
\hline Tax Rate & 39.51 & 27.14 & 28.19 & 26.12 \\
\hline Spending PC & 10.24 & 10.33 & 13.72 & 13.75 \\
\hline \multicolumn{5}{|l|}{ Panel C. 1930} \\
\hline Tax Revenues PC & 23.39 & 27.84 & 33.77 & 35.32 \\
\hline Property Taxes PC & 22.59 & 25.49 & 30.90 & 32.50 \\
\hline Tax Rate & 46.22 & 27.91 & 36.59 & 30.85 \\
\hline Spending PC & 20.59 & 23.98 & 29.98 & 31.30 \\
\hline
\end{tabular}

Table A7. Push Factors and Southern Black Migration Rates, by Decade

\begin{tabular}{|c|c|c|c|}
\hline Dep. Variable: & & Net Migratio & \\
\hline & (1) & $(2)$ & (3) \\
\hline Share Blacks & $-0.170 * * *$ & -0.041 & $-0.215 * * *$ \\
\hline & $(0.048)$ & $(0.045)$ & $(0.052)$ \\
\hline Rural Share & $-0.257 * * *$ & $-0.163 * * *$ & $-0.333 * * *$ \\
\hline & $(0.064)$ & $(0.045)$ & $(0.052)$ \\
\hline Share Cultivated Cotton & $0.292 * * *$ & $0.295 * * *$ & -0.105 \\
\hline & $(0.105)$ & $(0.100)$ & $(0.085)$ \\
\hline 1[Boll Weevil] & -0.034 & 0.030 & $-0.052 * *$ \\
\hline & $(0.051)$ & $(0.019)$ & $(0.020)$ \\
\hline Observations & 1,002 & 989 & 937 \\
\hline Decade & $1900-1910$ & $1910-1920$ & $1920-1930$ \\
\hline $\begin{array}{l}\text { Note: the dependent variable } \\
\text { The regressors refer to begin } \\
\text { cotton pest in the previous } \\
\text { dummy is equal to one for th } \\
\text { p }<0.01 \text {, ** }<<0.05, * p<0.1 \text {. }\end{array}$ & $\begin{array}{l}\text { migration rate } \\
\text { variables. The } \\
\text { county was hi } \\
\text { cade). Robust s }\end{array}$ & $\begin{array}{l}\text { in each of the } \\
\text { ummy is equa } \\
\text { weevil betwee } \\
\text { clustered at th }\end{array}$ & $\begin{array}{l}\text { s listed in Ta } \\
\text { ounty was hit } \\
900 \text {, the boll } \\
\text { l, in parenthe }\end{array}$ \\
\hline
\end{tabular}


Table A8. First Stage: Robustness Checks

\begin{tabular}{|c|c|c|c|c|c|c|c|c|}
\hline VARIABLES & $\begin{array}{c}(1) \\
\text { Blacks }\end{array}$ & $\begin{array}{c}\text { (2) } \\
\text { Whites }\end{array}$ & $\begin{array}{c}(3) \\
\text { Blacks }\end{array}$ & $\begin{array}{c}\text { (4) } \\
\text { Whites }\end{array}$ & $\begin{array}{c}(5) \\
\text { Blacks }\end{array}$ & $\begin{array}{c}\text { (6) } \\
\text { Whites }\end{array}$ & $\begin{array}{c}\text { (7) } \\
\text { Blacks }\end{array}$ & $\begin{array}{c}(8) \\
\text { Whites }\end{array}$ \\
\hline $\mathrm{Z}$ & $\begin{array}{c}1.711^{* * *} * \\
(0.536)\end{array}$ & $\begin{array}{l}-0.193 \\
(1.577)\end{array}$ & $\begin{array}{c}1.732 * * * \\
(0.548)\end{array}$ & $\begin{array}{c}0.101 \\
(1.373)\end{array}$ & $\begin{array}{c}1.718 * * * \\
(0.536)\end{array}$ & $\begin{array}{l}-0.294 \\
(1.526)\end{array}$ & $\begin{array}{c}1.545^{* *} \\
(0.637)\end{array}$ & $\begin{array}{l}-2.333 \\
(1.944)\end{array}$ \\
\hline Z_water & $\begin{array}{c}0.035^{* *} \\
(0.016)\end{array}$ & $\begin{array}{c}0.360 * * * \\
(0.094)\end{array}$ & $\begin{array}{c}0.038^{* *} \\
(0.015)\end{array}$ & $\begin{array}{c}0.369 * * * \\
(0.088)\end{array}$ & $\begin{array}{l}0.032 * \\
(0.018)\end{array}$ & $\begin{array}{c}0.334 * * * \\
(0.099)\end{array}$ & $\begin{array}{l}0.032 * \\
(0.016)\end{array}$ & $\begin{array}{c}0.400 * * * \\
(0.070)\end{array}$ \\
\hline Z_hills & $\begin{array}{l}-0.032 \\
(0.029)\end{array}$ & $\begin{array}{c}0.510 * * * \\
(0.142)\end{array}$ & $\begin{array}{l}-0.058 \\
(0.103)\end{array}$ & $\begin{array}{c}0.317 \\
(0.333)\end{array}$ & $\begin{array}{l}-0.044 \\
(0.032)\end{array}$ & $\begin{array}{c}0.479 * * * \\
(0.142)\end{array}$ & $\begin{array}{l}-0.039 \\
(0.031)\end{array}$ & $\begin{array}{c}0.527 * * \\
(0.246)\end{array}$ \\
\hline Z_rivers & $\begin{array}{c}-0.299 * * \\
(0.140)\end{array}$ & $\begin{array}{c}0.832 \\
(0.865)\end{array}$ & $\begin{array}{c}-0.302 * * \\
(0.129)\end{array}$ & $\begin{array}{c}0.910 \\
(0.843)\end{array}$ & $\begin{array}{l}-0.206 \\
(0.150)\end{array}$ & $\begin{array}{c}1.408 \\
(1.022)\end{array}$ & $\begin{array}{l}-0.177 \\
(0.194)\end{array}$ & $\begin{array}{l}1.837 * \\
(1.090)\end{array}$ \\
\hline $\begin{array}{l}\text { KP F-stat } \\
\text { AP F-stat }\end{array}$ & $\begin{array}{l}12.47 \\
61.63\end{array}$ & $\begin{array}{l}12.47 \\
113.6\end{array}$ & $\begin{array}{l}24.84 \\
66.02\end{array}$ & $\begin{array}{l}24.84 \\
137.8\end{array}$ & $\begin{array}{c}14.59 \\
88.6\end{array}$ & $\begin{array}{l}14.59 \\
349.0\end{array}$ & $\begin{array}{l}5.112 \\
102.3\end{array}$ & $\begin{array}{l}5.112 \\
415.4\end{array}$ \\
\hline Drop 95pct & Water & Water & Hills & Hills & Rivers & Rivers & - & - \\
\hline Radius & 50 & 50 & 50 & 50 & 50 & 50 & 30 & 30 \\
\hline Cities & 39 & 39 & 39 & 39 & 39 & 39 & 42 & 42 \\
\hline Observations & 117 & 117 & 117 & 117 & 117 & 117 & 126 & 126 \\
\hline
\end{tabular}

Note: The sample includes, for Census years 1910, 1920, and 1930, the 42 largest central cities that were anchored to a MSA and had at least 100,000 residents in 1930, and for which it was possible to construct the instrument for black migration. The dependent variable is the number of blacks (whites) in odd (even) columns. The regressors of interest are predicted black immigration $(Z)$ and its interaction with the share of the area around the central city: i) occupied by lakes and oceans ( $Z \_$water); ii) with slope above $15 \%$ ( $Z \_$hills); iii) occupied by rivers and streams ( $Z$ _rivers). All regressions control for city and year by region fixed effects, and include interactions between year dummies and dummies for the presence of geographic features around the central city. Cols 1-2, 3-4, and 5-6 drop, respectively, cities with the share of lakes and oceans, land with slope above $15 \%$, and rivers and stream above the $95^{\text {th }}$ percentile. Cols $7-8$ replicate results in the main text (Cols 4-5, Table 3) defining each geographic variables using a $30 \mathrm{~km}$ radius. AP F-stat refers to the partial F-stat for joint significance of the instruments in the two separate first-stage regressions. KP F-stat is the Kleibergen-Paap F stat for joint significance of instruments. Robust standard errors, clustered at the MSA level, in parentheses; *** $\mathrm{p}<0.01, * * \mathrm{p}<0.05, * \mathrm{p}<0.1$ 


\section{Table A9. Tax Revenues, Tax Rate, and Property Values: Push Factors IV}

\begin{tabular}{|c|c|c|c|c|c|c|c|}
\hline VARIABLES & $\begin{array}{c}\text { (1) } \\
\text { Tot. tax } \\
\text { revenues PC }\end{array}$ & $\begin{array}{c}\text { (2) } \\
\text { Prop. tax } \\
\text { revenues PC }\end{array}$ & $\begin{array}{c}\text { (3) } \\
\text { Prop. tax } \\
\text { revenues PC }\end{array}$ & $\begin{array}{c}\text { (4) } \\
\text { Prop. tax rate }\end{array}$ & $\begin{array}{c}(5) \\
\text { Prop. values over } \\
1900 \text { population }\end{array}$ & $\begin{array}{c}(6) \\
\text { Prop. values over } \\
1910 \text { population } \\
\end{array}$ & $\begin{array}{c}(7) \\
\text { Prop. values } \\
\text { PC } \\
\end{array}$ \\
\hline \multicolumn{8}{|c|}{ Panel A: Push Factors IV } \\
\hline Blacks & $\begin{array}{c}-0.131 * * * \\
(0.036)\end{array}$ & $\begin{array}{c}-0.121 * * * \\
(0.034)\end{array}$ & $\begin{array}{c}-0.161 * * * \\
(0.038)\end{array}$ & $\begin{array}{c}0.132 * * \\
(0.063)\end{array}$ & $\begin{array}{c}-35.48 * * \\
(17.24)\end{array}$ & $\begin{array}{c}-13.93 * * \\
(6.075)\end{array}$ & $\begin{array}{c}-8.435^{* * * *} \\
(3.206)\end{array}$ \\
\hline Whites & $\begin{array}{c}0.015 * * * \\
(0.005)\end{array}$ & $\begin{array}{c}0.012 * * \\
(0.005)\end{array}$ & $\begin{array}{c}0.017 * * * \\
(0.006)\end{array}$ & $\begin{array}{c}-0.021 * * \\
(0.010)\end{array}$ & $\begin{array}{l}4.525^{*} \\
(2.570)\end{array}$ & $\begin{array}{l}1.586^{*} \\
(0.882)\end{array}$ & $\begin{array}{c}1.096 * * \\
(0.507)\end{array}$ \\
\hline KP F-stat & 23.86 & 23.86 & 16.41 & 16.41 & 16.41 & 16.41 & 16.41 \\
\hline AP (Blacks) & 138.8 & 138.8 & 72.71 & 72.71 & 72.71 & 72.71 & 72.71 \\
\hline AP (Whites) & 261.4 & 261.4 & 192.9 & 192.9 & 192.9 & 192.9 & 192.9 \\
\hline Mean dep var & 15.63 & 15.16 & 15.16 & 23.12 & 1,308 & 860.1 & 860.1 \\
\hline Observations & 126 & 126 & 126 & 126 & 126 & 126 & 126 \\
\hline \multicolumn{8}{|c|}{$\begin{array}{l}\text { Note: The sample includes, for Census years 1910, 1920, and 1930, the } 42 \text { largest central cities that were anchored to a MSA and had at least } 100,000 \text { residents in } \\
\text { 1930, and for which it was possible to construct the instrument for black migration. The Table reports } 2 \text { SLS results obtained by predicting southern outmigration } \\
\text { using county-specific "push factors" (see equation (3) in the main text). The dependent variable is displayed at the top of each column, and refers to } 1910 \text { dollars. The } \\
\text { regressors of interest are the number of blacks (Blacks) and whites (Whites) in the central city. Coefficients should be interpreted as the effect of an additional } 1,000 \\
\text { blacks and whites respectively. AP (Blacks) and AP (Whites) refer to the partial F-stats for joint significance of the instruments in the two separate first-stage } \\
\text { regressions. KP F-stat is the Kleibergen-Paap F stat for joint significance of instruments. All columns also report the mean of the dependent variable at baseline. All } \\
\text { regressions control for city and year by region fixed effects. Cols } 3 \text { to } 7 \text { also include interactions between year dummies and dummies for: i) 1900 fraction of blacks; } \\
\text { ii) latitude and longitude; and iii) the presence of geographic features around the central city. Robust standard errors, clustered at the MSA level, in parentheses; *** } \\
\text { p }<0.01, * * p<0.05, * p<0.1 \text {. }\end{array}$} \\
\hline
\end{tabular}

\section{Table A10. Public Spending Per Capita: Push Factors IV}

\begin{tabular}{lcccccccc}
\hline VARIABLES & $\begin{array}{c}(1) \\
\text { Total }\end{array}$ & $\begin{array}{c}(2) \\
\text { Education }\end{array}$ & $\begin{array}{c}(3) \\
\text { Police }\end{array}$ & $\begin{array}{c}(4) \\
\text { Fire }\end{array}$ & $\begin{array}{c}(5) \\
\text { Sewerage } \\
\text { and garbage }\end{array}$ & $\begin{array}{c}(6) \\
\text { Road }\end{array}$ & $\begin{array}{c}(7) \\
\text { Charities and } \\
\text { hospitals }\end{array}$ & $\begin{array}{c}(8) \\
\text { Outdoor } \\
\text { poverty relief }\end{array}$ \\
\hline Panel A: Push Factors IV & & & & & & & \\
Blacks & $-0.076^{*}$ & $-0.052^{* * *}$ & $-0.008^{* *}$ & -0.006 & $-0.007 * * *$ & -0.011 & -0.009 & $-0.010^{* * *}$ \\
& $(0.043)$ & $(0.018)$ & $(0.004)$ & $(0.004)$ & $(0.002)$ & $(0.007)$ & $(0.007)$ & $(0.004)$ \\
Whites & 0.008 & $0.006^{* *}$ & $0.001^{* *}$ & 0.001 & $0.001 * * *$ & 0.000 & 0.000 & $0.001 * *$ \\
& $(0.007)$ & $(0.003)$ & $(0.001)$ & $(0.001)$ & $(0.000)$ & $(0.001)$ & $(0.001)$ & $(0.000)$ \\
KP F-stat & 16.41 & 16.41 & 16.41 & 16.41 & 16.41 & 16.41 & 13.78 & 80.25 \\
AP (Blacks) & 72.71 & 72.71 & 72.71 & 72.71 & 72.71 & 72.71 & 67.03 & 70.86 \\
AP (Whites) & 192.9 & 192.9 & 192.9 & 192.9 & 192.9 & 192.9 & 217.7 & 632.7 \\
Mean dep var & 15.21 & 4.656 & 1.812 & 1.801 & 1.802 & 1.043 & 1.892 & 0.144 \\
Observations & 126 & 126 & 126 & 126 & 126 & 126 & 42 \\
\hline
\end{tabular}

Note: The sample includes, for Census years 1910, 1920, and 1930, the 42 largest central cities that were anchored to a MSA and had at least 100,000 residents in 1930, and for which it was possible to construct the instrument for black migration, as discussed in the main text. The Table reports 2 SLS results obtained by predicting southern outmigration using county-specific "push factors" (see equation (3) in the main text). Coefficients should be interpreted as the effect of an additional 1,000 blacks and whites respectively. AP (Blacks) and AP (Whites) refer to the partial F-stats for joint significance of the instruments in the two separate first-stage regressions. KP F-stat is the Kleibergen-Paap F stat for joint significance of instruments. Data on spending for outdoor poverty relief (Col 8) were digitized from Geddes (1937), and are available only for the 14 largest cities in my sample. All columns report the mean of the dependent variable at baseline. All regressions include city and year by region fixed effects, and, except for Col 8, interactions between year dummies and dummies for: i) 1900 fraction of blacks; ii) latitude and longitude; and iii) the presence of geographic features around the central city. Robust standard errors, clustered at the MSA level, in parentheses; $* * * \mathrm{p}<0.1$ 


\section{Table A11. Spending Shares: Push Factors IV}

\begin{tabular}{|c|c|c|c|c|c|c|}
\hline VARIABLES & $\begin{array}{c}\text { (1) } \\
\text { Education }\end{array}$ & $\begin{array}{c}\text { (2) } \\
\text { Police }\end{array}$ & $\begin{array}{l}(3) \\
\text { Fire }\end{array}$ & $\begin{array}{c}\text { (4) } \\
\text { Sewerage and } \\
\text { garbage }\end{array}$ & $\begin{array}{c}(5) \\
\text { Road }\end{array}$ & $\begin{array}{c}\text { (6) } \\
\text { Charities and } \\
\text { hospitals } \\
\end{array}$ \\
\hline \multicolumn{7}{|c|}{ Panel A: Push Factors IV } \\
\hline Blacks & $\begin{array}{c}-0.064 * * \\
(0.032)\end{array}$ & $\begin{array}{l}-0.025 \\
(0.015)\end{array}$ & $\begin{array}{c}0.026 * * * \\
(0.010)\end{array}$ & $\begin{array}{c}-0.022 * \\
(0.013)\end{array}$ & $\begin{array}{c}0.002 \\
(0.030)\end{array}$ & $\begin{array}{c}-0.029^{*} \\
(0.017)\end{array}$ \\
\hline Whites & $\begin{array}{c}0.008 * \\
(0.004)\end{array}$ & $\begin{array}{c}0.004 * \\
(0.002)\end{array}$ & $\begin{array}{l}-0.002 \\
(0.002)\end{array}$ & $\begin{array}{c}0.004 * * \\
(0.002)\end{array}$ & $\begin{array}{l}-0.002 \\
(0.004)\end{array}$ & $\begin{array}{c}0.002 \\
(0.002)\end{array}$ \\
\hline KP F-stat & 16.41 & 16.41 & 16.41 & 16.41 & 16.41 & 13.78 \\
\hline AP (Blacks) & 72.71 & 72.71 & 72.71 & 72.71 & 72.71 & 67.03 \\
\hline AP (Whites) & 192.9 & 192.9 & 192.9 & 192.9 & 192.9 & 217.7 \\
\hline Mean dep var & 31.87 & 11.77 & 12.31 & 6.919 & 12.29 & 4.796 \\
\hline Observations & 126 & 126 & 126 & 126 & 126 & 122 \\
\hline
\end{tabular}

\section{Table A12. Spending on Education, Students Enrolled, and Literacy}

\begin{tabular}{|c|c|c|c|c|}
\hline VARIABLES & $\begin{array}{c}(1) \\
\text { Education spending over } \\
\text { pop below } 20\end{array}$ & $\begin{array}{l}\text { (2) } \\
\text { Education spending per } \\
\text { enrolled pupil }\end{array}$ & $\begin{array}{c}(3) \\
\text { Fr. population below } 20 \\
\text { enrolled in school }\end{array}$ & $\begin{array}{c}(4) \\
\text { Fraction literate whites } \\
\text { above } 10\end{array}$ \\
\hline \multicolumn{5}{|l|}{ Panel A: OLS } \\
\hline Blacks & $\begin{array}{c}-0.132 * * \\
(0.053)\end{array}$ & $\begin{array}{c}-0.147 * * \\
(0.064)\end{array}$ & $\begin{array}{l}-0.031 \\
(0.025)\end{array}$ & $\begin{array}{c}0.003 \\
(0.003)\end{array}$ \\
\hline Whites & $\begin{array}{l}0.018^{*} \\
(0.009)\end{array}$ & $\begin{array}{l}0.021^{*} \\
(0.011)\end{array}$ & $\begin{array}{c}0.005 \\
(0.003)\end{array}$ & $\begin{array}{l}-0.001 \\
(0.001)\end{array}$ \\
\hline \multicolumn{5}{|l|}{ Panel B: $2 S L S$} \\
\hline Blacks & $\begin{array}{c}-0.148 * * * \\
(0.051)\end{array}$ & $\begin{array}{c}-0.172 * * \\
(0.068)\end{array}$ & $\begin{array}{c}-0.032 \\
(0.024)\end{array}$ & $\begin{array}{c}0.001 \\
(0.004)\end{array}$ \\
\hline Whites & $\begin{array}{c}0.020^{* *} \\
(0.008)\end{array}$ & $\begin{array}{c}0.024 * * \\
(0.011)\end{array}$ & $\begin{array}{c}0.004 \\
(0.004)\end{array}$ & $\begin{array}{l}-0.000 \\
(0.001)\end{array}$ \\
\hline KP F-stat & 11.44 & 11.44 & 11.93 & 11.93 \\
\hline AP (Blacks) & 104.5 & 104.5 & 104.1 & 104.1 \\
\hline AP (Whites) & 254.9 & 254.9 & 230.8 & 230.8 \\
\hline Mean of dep var & 18.52 & 29.83 & 61.63 & 3.327 \\
\hline Observations & 126 & 126 & 124 & 124 \\
\hline \multicolumn{5}{|c|}{ 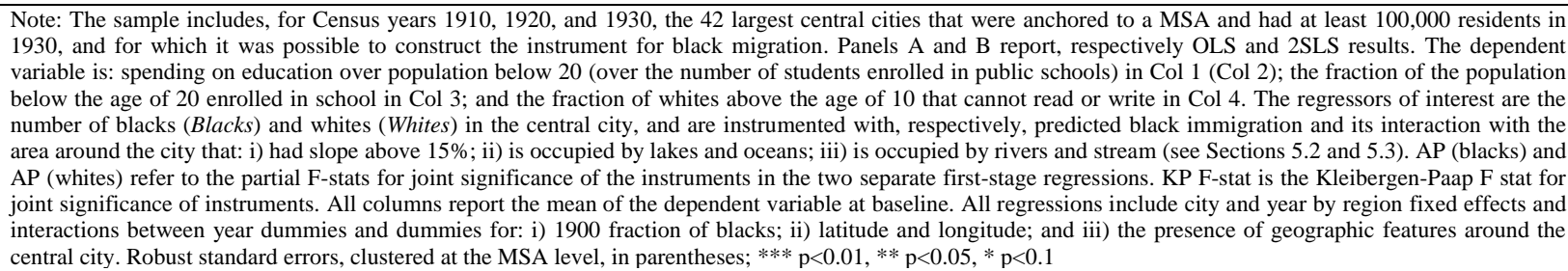 } \\
\hline
\end{tabular}


Table A13. Public Debt: Push Factors IV

\begin{tabular}{|c|c|c|c|c|}
\hline VARIABLES & $\begin{array}{c}(1) \\
\text { Total gross debt }\end{array}$ & $\begin{array}{c}\text { (2) } \\
\text { Current gross debt }\end{array}$ & $\begin{array}{c}(3) \\
\text { Net debt }\end{array}$ & $\begin{array}{c}\text { (4) } \\
\text { Debt to tax revenues ratio }\end{array}$ \\
\hline \multicolumn{5}{|c|}{ Panel A: Push Factors IV } \\
\hline Blacks & $\begin{array}{l}0.477 * * \\
(0.233)\end{array}$ & $\begin{array}{c}0.267 \\
(0.166)\end{array}$ & $\begin{array}{c}0.243 \\
(0.195)\end{array}$ & $\begin{array}{l}0.051 * * * \\
(0.011)\end{array}$ \\
\hline Whites & $\begin{array}{l}-0.062 * \\
(0.032)\end{array}$ & $\begin{array}{l}-0.029 \\
(0.021)\end{array}$ & $\begin{array}{c}-0.058 * * \\
(0.026)\end{array}$ & $\begin{array}{c}-0.006 * * * \\
(0.002)\end{array}$ \\
\hline KP F-stat & 16.41 & 16.41 & 16.41 & 16.41 \\
\hline AP (Blacks) & 72.71 & 72.71 & 72.71 & 72.71 \\
\hline AP (Whites) & 192.9 & 192.9 & 192.9 & 192.9 \\
\hline Mean dep var & 67.09 & 10.58 & 47.11 & 4.222 \\
\hline Observations & 126 & 126 & 126 & 126 \\
\hline \multicolumn{5}{|c|}{$\begin{array}{l}\text { Note: The sample includes, for Census years 1910, 1920, and 1930, the } 42 \text { largest central cities that were anchored to a MSA and had at least } 100,000 \text { residents in } \\
\text { 1930, and for which it was possible to construct the instrument for black migration. The Table reports } 2 \text { SLS results obtained by predicting southern outmigration } \\
\text { using county-specific "push factors" (see equation (3) in the main text). The dependent variable, expressed in } 1910 \text { dollars, is displayed at the top of each column and } \\
\text { refers to per capita values. In Col 4, the dependent variable is the ratio of total debt to total tax revenues. The regressors of interest are the number of blacks (Blacks } \\
\text { and whites (Whites) in the central city. Coefficients should be interpreted as the effect of an additional } 1,000 \text { blacks and whites respectively. AP (blacks) and AP } \\
\text { (whites) refer to the partial F-stats for joint significance of the instruments in the two separate first-stage regressions. KP F-stat is the Kleibergen-Paap F stat for join } \\
\text { significance of instruments. All columns also report the mean of the dependent variable at baseline. All regressions include city and year by region fixed effects and } \\
\text { interactions between year dummies and dummies for: i) } 1900 \text { fraction of blacks; ii) latitude and longitude; and iii) the presence of geographic features around the } \\
\text { central city. Robust standard errors, clustered at the MSA level, in parentheses; } * * * p<0.01, * * p<0.05, * p<0.1 \text {. }\end{array}$} \\
\hline
\end{tabular}

Table A14. Additional Evidence on the White Flight

\begin{tabular}{|c|c|c|c|c|c|c|c|}
\hline VARIABLES & $\begin{array}{c}\text { (1) } \\
\text { Housing } \\
\text { units } \\
\end{array}$ & $\begin{array}{c}(2) \\
\text { City area }\end{array}$ & $\begin{array}{c}(3) \\
\text { Planned rays } \\
(1944) \\
\end{array}$ & $\begin{array}{c}(4) \\
\text { Actual rays } \\
(1970-1950) \\
\end{array}$ & $\begin{array}{c}5) \\
\text { Actual rays } \\
(2000-1950) \\
\end{array}$ & $\begin{array}{c}\text { (6) } \\
\text { Municipalities } \\
(1970-1940) \\
\end{array}$ & $\begin{array}{c}(7) \\
\text { Special districts } \\
(1970-1940) \\
\end{array}$ \\
\hline \multicolumn{8}{|l|}{ Panel A: OLS } \\
\hline Blacks & $\begin{array}{l}-4.080 \\
(2.589)\end{array}$ & $\begin{array}{l}-1.464 \\
(0.945)\end{array}$ & $\begin{array}{c}0.016^{* *} \\
(0.008)\end{array}$ & $\begin{array}{c}0.028 * * * \\
(0.008)\end{array}$ & $\begin{array}{c}0.029 * * * \\
(0.008)\end{array}$ & $\begin{array}{c}0.128 \\
(0.148)\end{array}$ & $\begin{array}{c}1.665 * * * \\
(0.215)\end{array}$ \\
\hline Whites & $\begin{array}{c}0.641 \\
(0.448)\end{array}$ & $\begin{array}{c}0.268 \\
(0.176)\end{array}$ & $\begin{array}{l}-0.001 \\
(0.001)\end{array}$ & $\begin{array}{c}-0.002 * \\
(0.001)\end{array}$ & $\begin{array}{l}-0.002 * \\
(0.001)\end{array}$ & $\begin{array}{c}0.001 \\
(0.021)\end{array}$ & $\begin{array}{c}-0.147 * * * \\
(0.032)\end{array}$ \\
\hline \multicolumn{8}{|l|}{ Panel B: 2SLS } \\
\hline Blacks & $\begin{array}{c}-5.720 * * \\
(2.522)\end{array}$ & $\begin{array}{l}-2.246^{*} \\
(1.298)\end{array}$ & $\begin{array}{c}0.025^{* *} \\
(0.011)\end{array}$ & $\begin{array}{c}0.041 * * * \\
(0.010)\end{array}$ & $\begin{array}{c}0.044 * * * \\
(0.010)\end{array}$ & $\begin{array}{c}0.371^{* *} \\
(0.168)\end{array}$ & $\begin{array}{c}1.578 * * * \\
(0.288)\end{array}$ \\
\hline Whites & $\begin{array}{l}0.669^{*} \\
(0.367)\end{array}$ & $\begin{array}{c}0.308 \\
(0.197)\end{array}$ & $\begin{array}{l}-0.002 \\
(0.001)\end{array}$ & $\begin{array}{c}-0.003 * * \\
(0.001)\end{array}$ & $\begin{array}{c}-0.004 * * * \\
(0.001)\end{array}$ & $\begin{array}{l}-0.030 \\
(0.026)\end{array}$ & $\begin{array}{c}-0.120 * * \\
(0.049)\end{array}$ \\
\hline KP F-stat & 11.79 & 11.79 & 11.27 & 11.27 & 11.27 & 11.39 & 11.39 \\
\hline AP (Blacks) & 102.6 & 102.6 & 63.35 & 63.35 & 63.35 & 66.99 & 66.99 \\
\hline AP (Whites) & 207.0 & 207.0 & 197.4 & 197.4 & 197.4 & 216.8 & 216.8 \\
\hline Mean dep var & 268.5 & 122.9 & 3.268 & 0.146 & 0.146 & 38 & 28 \\
\hline Observations & 125 & 125 & 41 & 41 & 41 & 42 & 42 \\
\hline
\end{tabular}

Note: The sample includes, for Census years 1910, 1920, and 1930, the 42 largest central cities that were anchored to a MSA and had at least 100,000 residents in 1930, and for which it was possible to construct the instrument for black migration. Panels A and B report, respectively, OLS and 2SLS results. The dependent variable is: the number of housing units divided by 1900 population in Col 1; land area (in square km) in Col 2; the number of highway rays passing through the city planned in the Federal Highway Act of 1944 in Col 3; the 1950-1970 (resp. 1950-200) change in the number of highway rays passing through the city in Col 4 (resp. Col 5); the 1940-1970 change in the number of special districts (resp. municipalities) in Col 6 (resp. Col 7). The regressors of interest are the number of blacks (Blacks) and whites (Whites) in the central city in Cols 1 and 2, and their 1910-1930 change in the remaining columns. They are instrumented with, respectively, predicted black immigration and its interaction with the area around the city that: i) had slope above $15 \%$; ii) is occupied by lakes and oceans; iii) is occupied by rivers and stream (see Sections 5.2 and 5.3). AP-stat (blacks) and AP-stat (whites) refer to the partial F-stats for joint significance of the instruments in the two separate first-stage regressions. KP F-stat is the Kleibergen-Paap F stat for joint significance of instruments. All columns also report the mean of the dependent variable at baseline. Cols 1 and 2 include city and year by region fixed effects, and interactions between year dummies and: i) 1900 fraction of blacks; ii) city coordinates; and iii) the presence of geographic features around the central city. Long difference regressions in Cols 3 to 7 partial out trends for: region; 1900 fraction of blacks; city coordinates; and geography. Robust standard errors, clustered at the MSA level, in parentheses; *** $\mathrm{p}<0.01, * * \mathrm{p}<0.05, * \mathrm{p}<0.1$ 


\section{Table A15. 1900-1910 Changes in European Immigration and in Economic Activity}

\begin{tabular}{|c|c|c|c|c|c|}
\hline & \multicolumn{5}{|c|}{ Dep. Variable: 1900-1910 Change in } \\
\hline & $\begin{array}{c}(1) \\
\text { Fr. Immigrants }\end{array}$ & $\begin{array}{c}\text { (2) } \\
\text { Log value added per } \\
\text { establishment }\end{array}$ & $\begin{array}{c}\text { (3) } \\
\text { Log value of products } \\
\text { per establishment }\end{array}$ & $\begin{array}{c}\text { (4) } \\
\text { Log establishment } \\
\text { size } \\
\end{array}$ & $\begin{array}{c}5) \\
\begin{array}{c}\text { Log manufacturing } \\
\text { wages }\end{array} \\
\end{array}$ \\
\hline Blacks & $\begin{array}{l}-0.005 \\
(0.019)\end{array}$ & $\begin{array}{c}-0.893 \\
(1.189)\end{array}$ & $\begin{array}{l}-2.729 \\
(2.381)\end{array}$ & $\begin{array}{l}-0.543 \\
(0.870)\end{array}$ & $\begin{array}{l}-0.067 \\
(0.314)\end{array}$ \\
\hline Whites & $\begin{array}{c}0.001 \\
(0.003)\end{array}$ & $\begin{array}{l}-0.027 \\
(0.175)\end{array}$ & $\begin{array}{c}0.262 \\
(0.370)\end{array}$ & $\begin{array}{l}-0.059 \\
(0.138)\end{array}$ & $\begin{array}{l}-0.004 \\
(0.044)\end{array}$ \\
\hline $\begin{array}{l}\text { KP F-stat } \\
\text { AP (Blacks) } \\
\text { AP (Whites) }\end{array}$ & $\begin{array}{l}11.23 \\
63.94 \\
207.7\end{array}$ & $\begin{array}{l}12.37 \\
69.96 \\
257.4\end{array}$ & $\begin{array}{l}12.37 \\
69.96 \\
257.4\end{array}$ & $\begin{array}{l}12.37 \\
69.96 \\
257.4\end{array}$ & $\begin{array}{l}12.37 \\
69.96 \\
257.4\end{array}$ \\
\hline Cities & 41 & 41 & 41 & 41 & 41 \\
\hline
\end{tabular}

\section{Table A16. Pre-Trends}

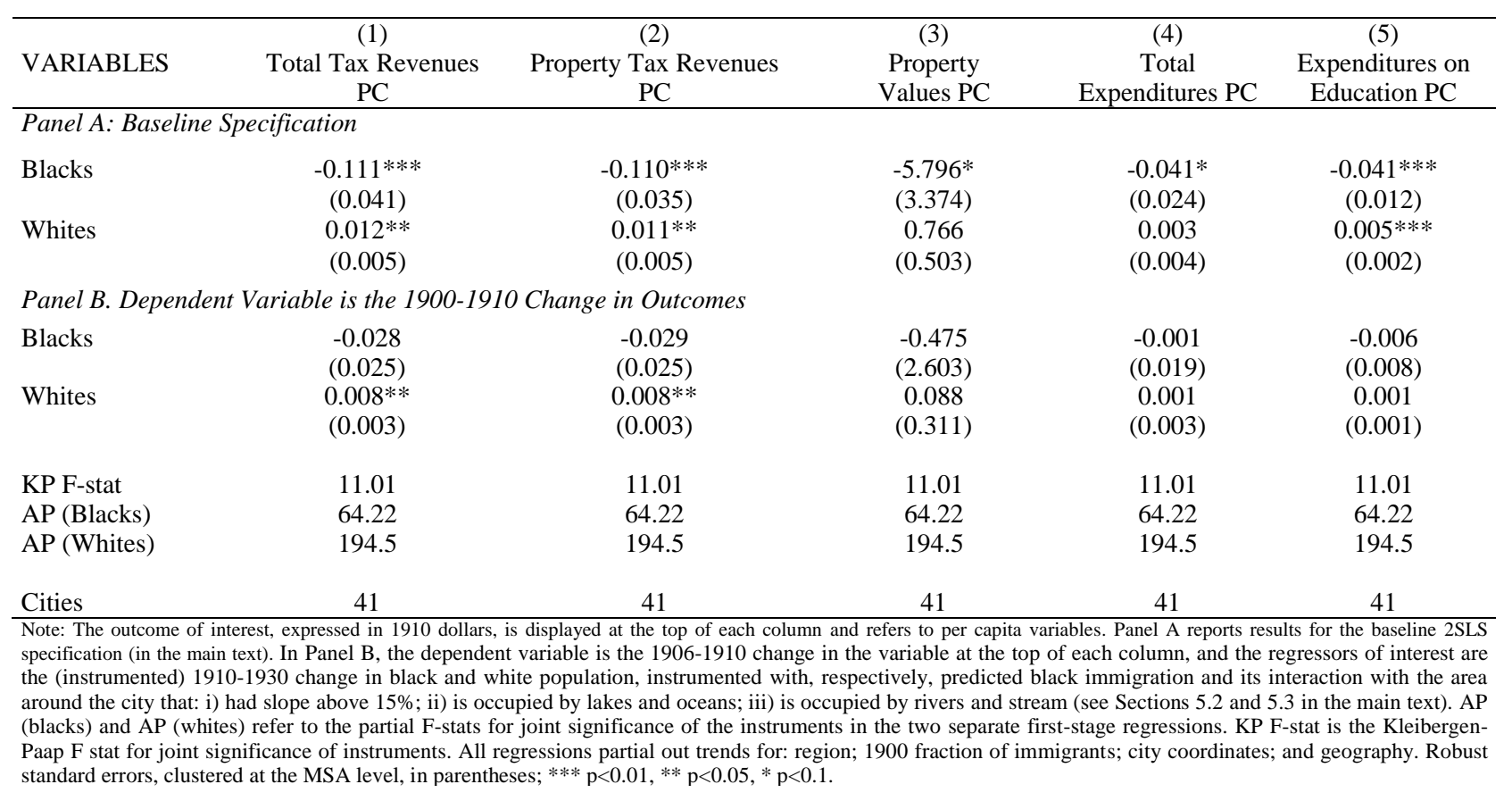




\section{Table A17. Differential Trends and 1900 Characteristics}

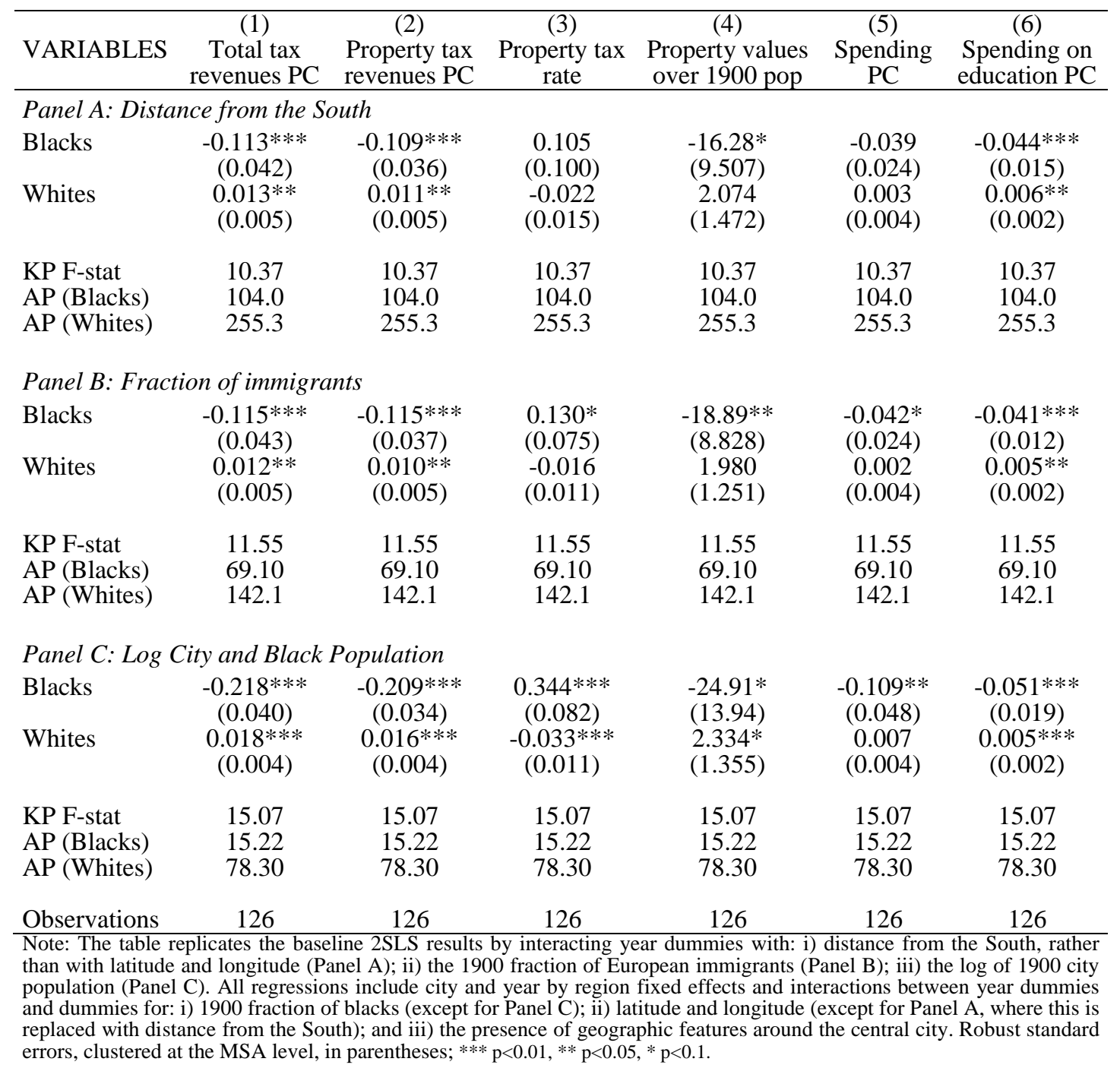


Table A18. Differential Trends and 1900 Characteristics

\begin{tabular}{|c|c|c|c|c|c|c|}
\hline VARIABLES & $\begin{array}{c}\text { (1) } \\
\text { Total tax } \\
\text { revenues PC }\end{array}$ & $\begin{array}{c}(2) \\
\text { Property tax } \\
\text { revenues PC }\end{array}$ & $\begin{array}{l}\text { (3) } \\
\text { Property tax } \\
\text { rate }\end{array}$ & $\begin{array}{c}(4) \\
\text { Property values } \\
\text { over } 1900 \text { pop }\end{array}$ & $\begin{array}{c}(5) \\
\text { Spending } \\
\text { PC } \\
\end{array}$ & $\begin{array}{c}(6) \\
\text { Spending on } \\
\text { education PC }\end{array}$ \\
\hline \multicolumn{7}{|c|}{ Panel A: Skill Ratios } \\
\hline Blacks & $\begin{array}{c}-0.120 * * * \\
(0.043)\end{array}$ & $\begin{array}{c}-0.115^{* * * *} \\
(0.036)\end{array}$ & $\begin{array}{c}0.082 \\
(0.065)\end{array}$ & $\begin{array}{c}-19.55^{* *} \\
(9.127)\end{array}$ & $\begin{array}{c}-0.049 * * \\
(0.025)\end{array}$ & $\begin{array}{c}-0.042 * * * \\
(0.012)\end{array}$ \\
\hline Whites & $\begin{array}{c}0.012 * * \\
(0.006)\end{array}$ & $\begin{array}{c}0.011 * * \\
(0.005)\end{array}$ & $\begin{array}{l}-0.018^{*} \\
(0.010)\end{array}$ & $\begin{array}{c}1.973 \\
(1.301)\end{array}$ & $\begin{array}{c}0.002 \\
(0.004)\end{array}$ & $\begin{array}{c}0.005 * * \\
(0.002)\end{array}$ \\
\hline $\begin{array}{l}\text { KP F-stat } \\
\text { AP (Blacks) } \\
\text { AP (Whites) }\end{array}$ & $\begin{array}{l}11.91 \\
57.07 \\
76.01\end{array}$ & $\begin{array}{l}11.91 \\
57.07 \\
76.01\end{array}$ & $\begin{array}{l}11.91 \\
57.07 \\
76.01\end{array}$ & $\begin{array}{l}11.91 \\
57.07 \\
76.01\end{array}$ & $\begin{array}{l}11.91 \\
57.07 \\
76.01\end{array}$ & $\begin{array}{l}11.91 \\
57.07 \\
76.01\end{array}$ \\
\hline \multicolumn{7}{|c|}{ Panel B: Value added by manufacture } \\
\hline Blacks & $\begin{array}{c}-0.103 * * \\
(0.043)\end{array}$ & $\begin{array}{c}-0.105 * * * \\
(0.036)\end{array}$ & $\begin{array}{c}0.082 \\
(0.074)\end{array}$ & $\begin{array}{c}-17.65^{*} \\
(9.102)\end{array}$ & $\begin{array}{c}-0.042 \\
(0.026)\end{array}$ & $\begin{array}{c}-0.043 * * * \\
(0.013)\end{array}$ \\
\hline Whites & $\begin{array}{c}0.011 * * \\
(0.005)\end{array}$ & $\begin{array}{c}0.010 * * \\
(0.005)\end{array}$ & $\begin{array}{c}-0.014 \\
(0.011)\end{array}$ & $\begin{array}{c}1.880 \\
(1.296)\end{array}$ & $\begin{array}{c}0.003 \\
(0.004)\end{array}$ & $\begin{array}{c}0.005 * * * \\
(0.002)\end{array}$ \\
\hline $\begin{array}{l}\text { KP F-stat } \\
\text { AP (Blacks) } \\
\text { AP (Whites) }\end{array}$ & $\begin{array}{l}11.58 \\
135.5 \\
310.5\end{array}$ & $\begin{array}{l}11.58 \\
135.5 \\
310.5\end{array}$ & $\begin{array}{l}11.58 \\
135.5 \\
310.5\end{array}$ & $\begin{array}{l}11.58 \\
135.5 \\
310.5\end{array}$ & $\begin{array}{l}11.58 \\
135.5 \\
310.5\end{array}$ & $\begin{array}{l}11.58 \\
135.5 \\
310.5\end{array}$ \\
\hline \multicolumn{7}{|c|}{ Panel C: Employment share manufacture } \\
\hline Blacks & $\begin{array}{c}-0.109 * * * \\
(0.041) \\
0.012 * * \\
(0.005)\end{array}$ & $\begin{array}{c}-0.109 * * * \\
(0.034) \\
0.011 * * \\
(0.005)\end{array}$ & $\begin{array}{c}0.096 \\
(0.071) \\
-0.015 \\
(0.011)\end{array}$ & $\begin{array}{c}-17.18^{* *} \\
(8.605) \\
1.879 \\
(1.225)\end{array}$ & $\begin{array}{c}-0.047 * \\
(0.026) \\
0.004 \\
(0.004)\end{array}$ & $\begin{array}{c}-0.043 * * * \\
(0.013) \\
0.005 * * * \\
(0.002)\end{array}$ \\
\hline $\begin{array}{l}\text { KP F-stat } \\
\text { AP (Blacks) } \\
\text { AP (Whites) }\end{array}$ & $\begin{array}{l}13.34 \\
96.48 \\
267.5\end{array}$ & $\begin{array}{l}13.34 \\
96.48 \\
267.5\end{array}$ & $\begin{array}{l}13.34 \\
96.48 \\
267.5\end{array}$ & $\begin{array}{l}13.34 \\
96.48 \\
267.5\end{array}$ & $\begin{array}{l}13.34 \\
96.48 \\
267.5\end{array}$ & $\begin{array}{l}13.34 \\
96.48 \\
267.5\end{array}$ \\
\hline Observations & 123 & 123 & 123 & 123 & 123 & 123 \\
\hline $\begin{array}{l}\text { Note: The table } \\
\text { log of } 1904 \text { value } \\
\text { C). All regressior } \\
1900 \text { fraction of } \\
\text { Robust standard }\end{array}$ & $\begin{array}{l}\text { licates the bas } \\
\text { dded by manu } \\
\text { include city an } \\
\text { acks; ii) latitu } \\
\text { ors, clustered }\end{array}$ & $\begin{array}{l}\text { SLS results } \\
\text { per establis } \\
\text { by region f } \\
\text { d longitude; } \\
\text { MSA level, }\end{array}$ & $\begin{array}{l}\text { interacting y } \\
\text { ent (Panel B) } \\
\text { effects and } \\
\text { iii) the pr } \\
\text { rentheses: }\end{array}$ & $\begin{array}{l}\text { ummies with: } \\
\text { the } 1900 \text { empl }\end{array}$ & $\begin{array}{l}\text { skill rati } \\
\text { share in } \\
\text { lummies }\end{array}$ & $\begin{array}{l}\text { anel A); ii) the } \\
\text { ufacture (Panel } \\
\text { dummies for: i) } \\
\text { ne central city. }\end{array}$ \\
\hline
\end{tabular}


Table A19. Trimming the Sample

\begin{tabular}{|c|c|c|c|c|c|c|}
\hline VARIABLES & $\begin{array}{c}(1) \\
\text { Total tax } \\
\text { revenues PC }\end{array}$ & $\begin{array}{c}(2) \\
\text { Property tax } \\
\text { revenues PC }\end{array}$ & $\begin{array}{c}\text { (3) } \\
\text { Property tax rate }\end{array}$ & $\begin{array}{c}(4) \\
\text { Property values } \\
\text { over 1900 pop }\end{array}$ & $\begin{array}{c}\text { (5) } \\
\text { Total spending } \\
\text { PC }\end{array}$ & $\begin{array}{c}(6) \\
\text { Spending on } \\
\text { education PC }\end{array}$ \\
\hline \multicolumn{7}{|c|}{ Panel A: $I^{s t}-99^{\text {th }}$ Percentiles } \\
\hline Blacks & $\begin{array}{l}-0.076^{*} \\
(0.040)\end{array}$ & $\begin{array}{c}-0.077 * * \\
(0.034)\end{array}$ & $\begin{array}{l}-0.019 \\
(0.160)\end{array}$ & $\begin{array}{l}-17.95 \\
(13.23)\end{array}$ & $\begin{array}{c}-0.065^{* * * *} \\
(0.025)\end{array}$ & $\begin{array}{c}-0.046 * * * \\
(0.018)\end{array}$ \\
\hline Whites & $\begin{array}{l}-0.000 \\
(0.010)\end{array}$ & $\begin{array}{c}0.000 \\
(0.009)\end{array}$ & $\begin{array}{c}0.000 \\
(0.040)\end{array}$ & $\begin{array}{c}3.072 \\
(3.266)\end{array}$ & $\begin{array}{c}0.012 * * \\
(0.006)\end{array}$ & $\begin{array}{l}0.009 * * \\
(0.004)\end{array}$ \\
\hline KP F-stat & 10.39 & 10.39 & 10.39 & 10.39 & 10.39 & 10.39 \\
\hline AP (Blacks) & 20.20 & 20.20 & 20.20 & 20.20 & 20.20 & 20.20 \\
\hline AP (Whites) & 16.50 & 16.50 & 16.50 & 16.50 & 16.50 & 16.50 \\
\hline Observations & 120 & 120 & 120 & 120 & 120 & 120 \\
\hline \multicolumn{7}{|c|}{ Panel B: $5^{\text {ht }}-95^{\text {th }}$ Percentiles } \\
\hline Blacks & $\begin{array}{c}-0.097 * * * \\
(0.038)\end{array}$ & $\begin{array}{c}-0.098 * * * \\
(0.032)\end{array}$ & $\begin{array}{l}-0.004 \\
(0.214)\end{array}$ & $\begin{array}{c}-30.09 * * \\
(14.59)\end{array}$ & $\begin{array}{c}-0.088 * * * \\
(0.023)\end{array}$ & $\begin{array}{c}-0.054 * * * \\
(0.020)\end{array}$ \\
\hline Whites & $\begin{array}{c}0.004 \\
(0.008)\end{array}$ & $\begin{array}{c}0.004 \\
(0.007)\end{array}$ & $\begin{array}{c}0.000 \\
(0.048)\end{array}$ & $\begin{array}{l}5.645^{*} \\
(3.166)\end{array}$ & $\begin{array}{c}0.017 * * * \\
(0.005)\end{array}$ & $\begin{array}{c}0.011 * * \\
(0.004)\end{array}$ \\
\hline KP F-stat & 8.011 & 8.011 & 8.011 & 8.011 & 8.011 & 8.011 \\
\hline AP (Blacks) & 35.28 & 35.28 & 35.28 & 35.28 & 35.28 & 35.28 \\
\hline AP (Whites) & 20.18 & 20.18 & 20.18 & 20.18 & 20.18 & 20.18 \\
\hline Observations & 108 & 108 & 108 & 108 & 108 & 108 \\
\hline \multicolumn{7}{|c|}{$\begin{array}{l}\text { Note: The sample includes, for Census years 1910, 1920, and 1930, the } 42 \text { largest central cities that were anchored to a MSA and had at least } 100,000 \text { residents in } \\
1930 \text {, and for which it was possible to construct the instrument for black migration. This Table replicates results in the main text trimming the sample at the } 1^{\text {st }} \text { and } \\
99^{\text {th }} \text { (Panel A) and at the } 5^{\text {th }} \text { and } 95^{\text {th }} \text { (Panel B) percentiles of black population. In Panel A, the excluded cities are New York and Duluth, while in Panel B they are } \\
\text { New York, Philadelphia, Washington DC, Duluth, San Diego, and Scranton. The outcome of interest, expressed in } 1910 \text { dollars, is displayed at the top of each } \\
\text { column. The regressors of interest are the number of blacks (Blacks) and whites (Whites) in the central city, and are instrumented with, respectively, predicted black } \\
\text { immigration and its interaction with the area around the city that: i) had slope above } 15 \% \text {; ii) is occupied by lakes and oceans; iii) is occupied by rivers and stream } \\
\text { (see Sections } 5.2 \text { and 5.3). AP (blacks) and AP (whites) refer to the partial F-stats for joint significance of the instruments in the two separate first-stage regressions. } \\
\text { KP F-stat is the Kleibergen-Paap F stat for joint significance of instruments. All regressions include city and year by region fixed effects and interactions between } \\
\text { year dummies and dummies for the presence of geographic features around the central city. Robust standard errors, clustered at the MSA level, in parentheses; *** } \\
\text { p }<0.01, * * \text { p }<0.05, * p<0.1\end{array}$} \\
\hline
\end{tabular}

Table A20. Alternative Instrument for the White Flight

\begin{tabular}{|c|c|c|c|c|c|c|}
\hline VARIABLES & $\begin{array}{c}(1) \\
\text { Total tax } \\
\text { revenues PC }\end{array}$ & $\begin{array}{c}\text { (2) } \\
\text { Property tax } \\
\text { revenues PC }\end{array}$ & $\begin{array}{c}\text { (3) } \\
\text { Property tax rate }\end{array}$ & $\begin{array}{c}\text { (4) } \\
\text { Property values } \\
\text { over } 1900 \text { pop } \\
\end{array}$ & $\begin{array}{c}(5) \\
\text { Total spending } \\
\text { PC } \\
\end{array}$ & $\begin{array}{c}(6) \\
\text { Spending on } \\
\text { education PC }\end{array}$ \\
\hline Blacks & $\begin{array}{c}-0.141 * * * \\
(0.047)\end{array}$ & $\begin{array}{c}-0.127 * * * \\
(0.042)\end{array}$ & $\begin{array}{c}0.015 \\
(0.237)\end{array}$ & $\begin{array}{c}-28.40 * * \\
(11.63)\end{array}$ & $\begin{array}{l}-0.060^{*} \\
(0.036)\end{array}$ & $\begin{array}{c}-0.047 * * \\
(0.018)\end{array}$ \\
\hline Whites & $\begin{array}{c}0.021 * * * \\
(0.007)\end{array}$ & $\begin{array}{c}0.017 * * * \\
(0.006)\end{array}$ & $\begin{array}{l}-0.016 \\
(0.032)\end{array}$ & $\begin{array}{l}4.605 * * \\
(2.023)\end{array}$ & $\begin{array}{c}0.008 \\
(0.006)\end{array}$ & $\begin{array}{c}0.007 * * \\
(0.003)\end{array}$ \\
\hline KP F-stat & 10.69 & 10.69 & 10.69 & 10.69 & 10.69 & 10.69 \\
\hline AP (Blacks) & 41.39 & 41.39 & 41.39 & 41.39 & 41.39 & 41.39 \\
\hline AP (Whites) & 14.06 & 14.06 & 14.06 & 14.06 & 14.06 & 14.06 \\
\hline Mean of dep var & 15.63 & 15.16 & 23.12 & 1,308 & 15.21 & 4.656 \\
\hline Observations & 126 & 126 & 126 & 126 & 126 & 126 \\
\hline
\end{tabular}




\section{Figure A1. Map of Cities}

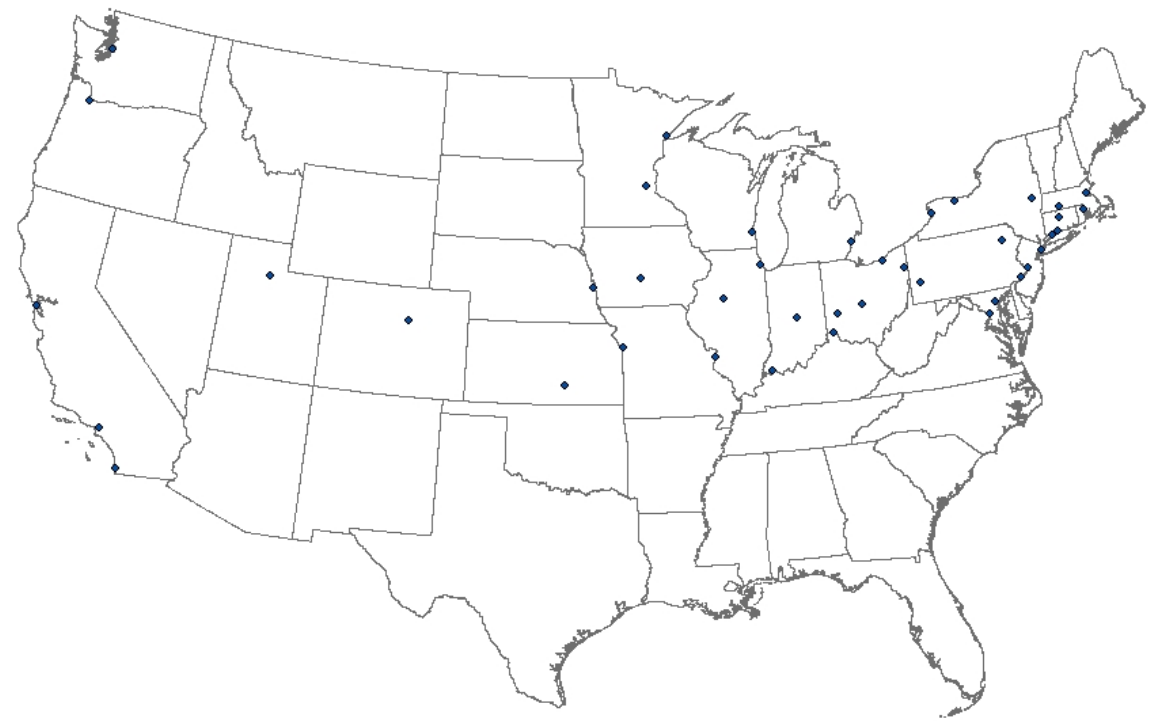

Note: the map plots the 42 largest central cities that were anchored to a MSA and had at least 100,000 residents in 1930, and for which it was possible to construct the instrument for black migration.

\section{Figure A2. Share of Spending Across Categories}

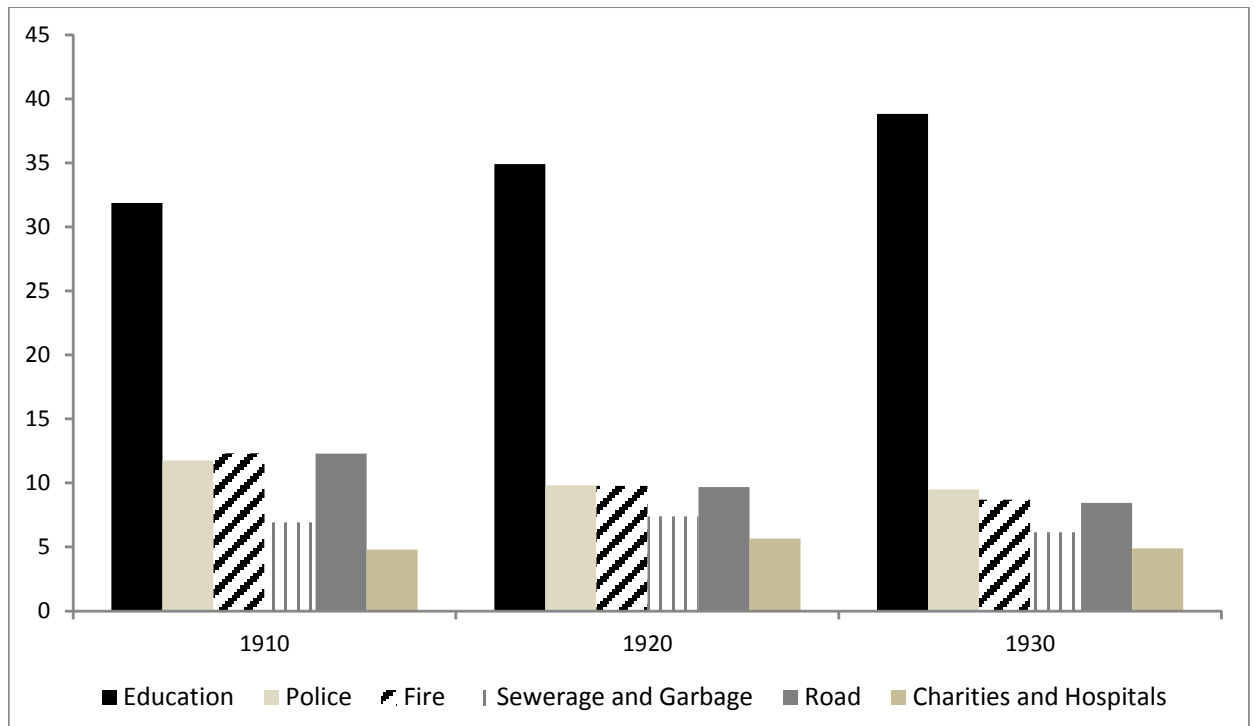

Note: this Figure plots the share of each spending category over total public expenses for the 42 cities in my sample, for 1910, 1920, and 1930. Source: Author's calculation from the Financial Statistics of Cities. 


\section{Figure A3. First Stage: Push Factors Instrument}

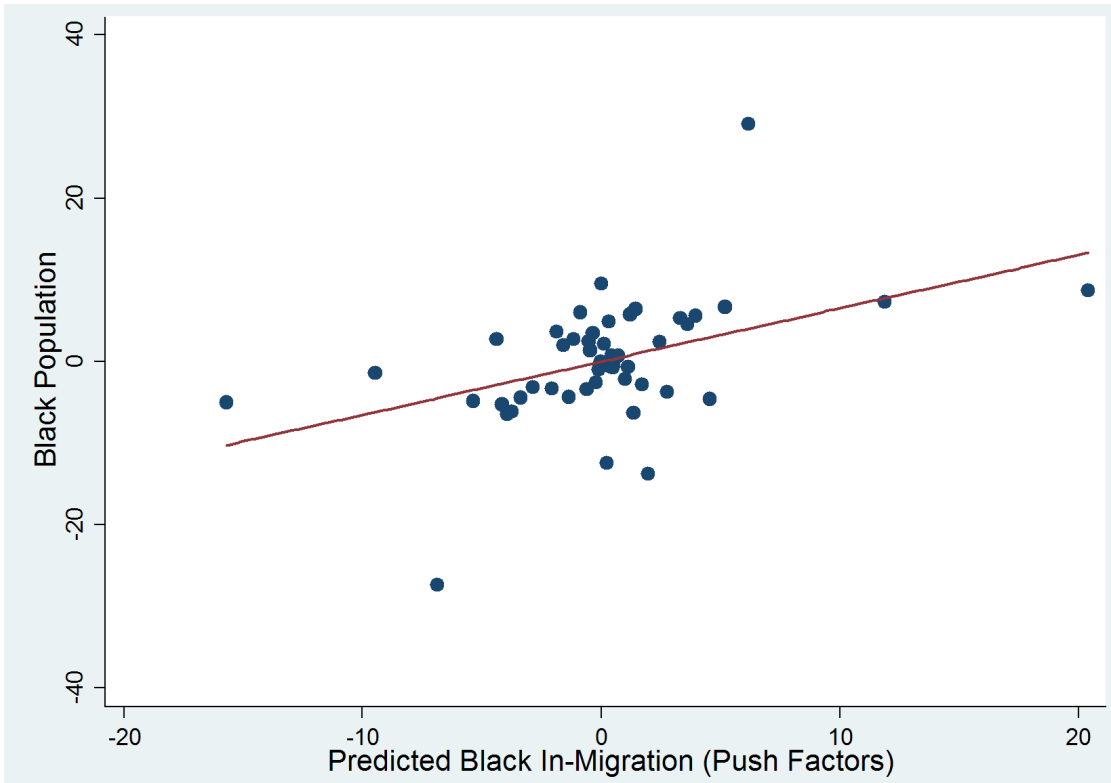

Note: The y-axis reports the actual number of blacks in northern cities in each decade between 1910 and 1930, and the xaxis shows the predicted number of black migrants, constructed exploiting southern push factors (Section 5.2.2). Each point in the bin-scatter diagram represents the residual change in a city's actual and predicted number of blacks after partialling out: the interaction between predicted black immigration and the geographic variables listed in the main text (Section 5.3); city and year by region fixed effects; interactions between year dummies geography.

\section{Figure A4. Predicted Black Inflows and Whites' Internal Migration}

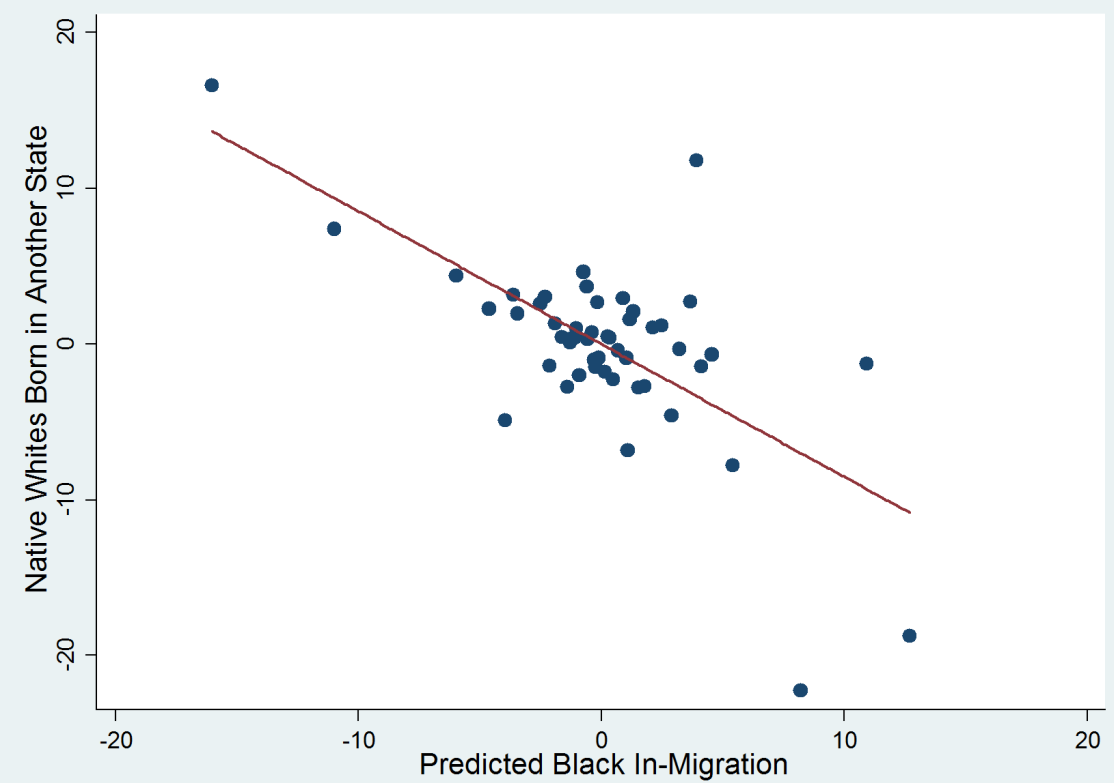

Note: The x-axis reports the predicted number of blacks in northern cities in each decade between 1910 and 1930, and the yaxis shows the number of native white household heads who were born in another state. Each point in the bin-scatter diagram represents the residual change of these variables after partialling out total MSA population, city and year by region fixed effects, and interactions between year dummies and: the fraction of blacks in 1900; and, latitude and longitude. The regression coefficient is -0.852 with standard errors (clustered at the MSA level) equal to 0.327 . 


\section{Figure A5. White In-Migration and 1900 Blacks' Settlements}

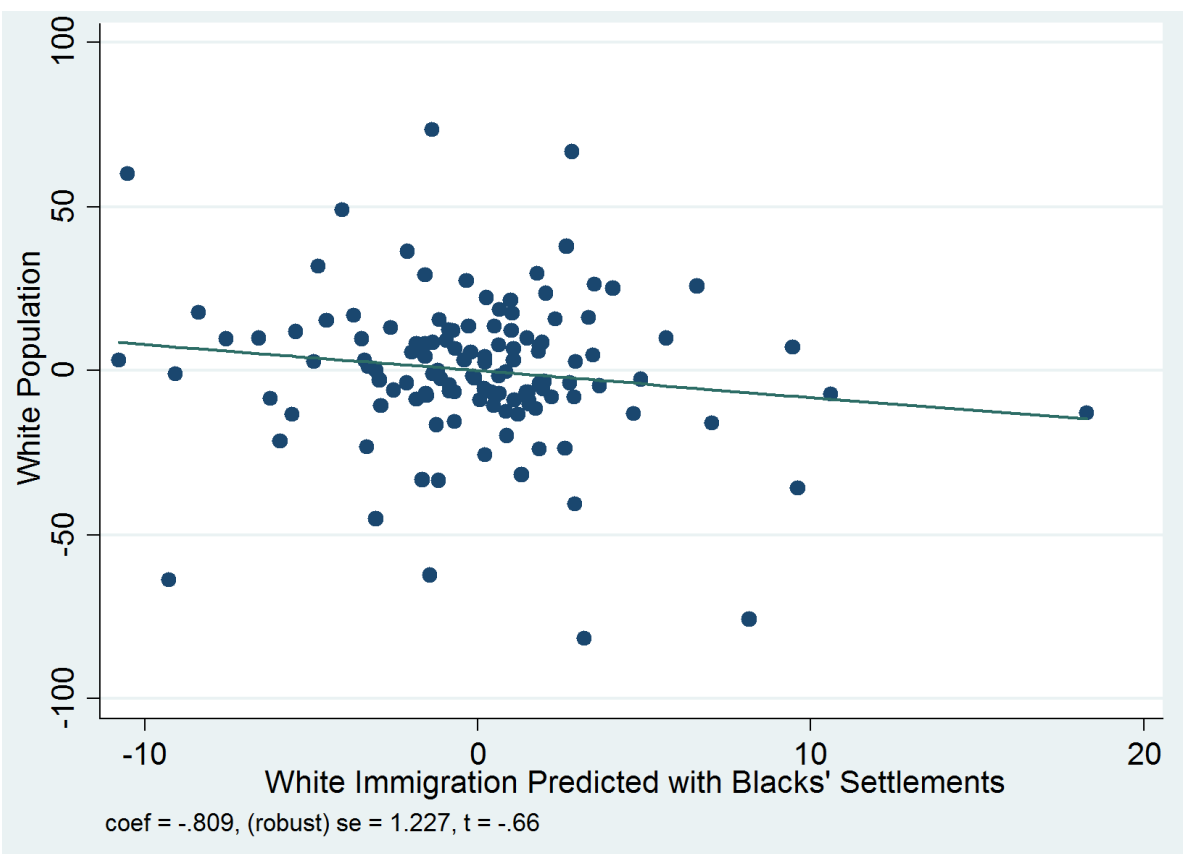

Note: The y-axis reports the actual number of whites received by Northern cities in each decade between 1910 and 1930 and the $\mathrm{x}$-axis shows the change in the predicted number of southern white migrants, constructed multiplying 1900 blacks' settlements with southern born white outmigration from each southern state. Each point in the scatter diagram represents the residual change in a city's actual and predicted number of whites after partialling out MSA population; city and year by region fixed effects; interactions between year dummies and 1900 fraction of blacks, city coordinates, and geography. 